WSRC-TR-2000-00348

Revision 0

\title{
Savannah River Site Ingestion Pathway Methodology Manual for Airborne Radioactive Releases
}

J. M. Thompson

E. A. Thompson

September 2000

Classification

UNCLASSIFIED

DOES NOT CONTAIN

UNCLASSIFIED CONTROLLED

NUCLEAR INFORMATION

\begin{tabular}{|c|c|}
\hline $\begin{array}{l}\text { ADC \& } \\
\text { Reviewing } \\
\text { Official: }\end{array}$ & K.R. OKula \\
\hline Date: & $9 / 28 / 00$ \\
\hline
\end{tabular}

Westinghouse Savannah River Company Aiken, SC 29808

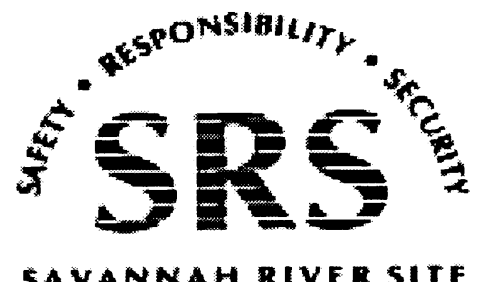

PREPARED FOR THE U.S. DEPARTMENT OF ENERGY UNDER CONTRACT NO. DE-AC09-96SR18500 


\section{DISCLAIMER}

This document was prepared by Westinghouse Safety Management Solutions LLC (WSMS) under contract with Westinghouse Savannah River Company (WSRC), subject to the warranty and other obligations of that contract and in furtherance of WSRC's contract with the United States Department of Energy (DOE).

Release to and Use by Third Parties. As it pertains to releases of this document to third parties, and the use of or reference to this document by such third parties in whole or in part, neither WSMS, WSRC, DOE, nor their respective officers, directors, employees, agents, consultants or personal services contractors (i) make any warranty, expressed or implied, (ii) assume any legal liability or responsibility for the accuracy, completeness, or usefulness, of any information, apparatus, product or process

disclosed herein or (iii) represent that use of the same will not infringe privately owned rights. Reference herein to any specific commercial product, process, or service by trademark, name, manufacture or otherwise, does not necessarily constitute or imply endorsement, recommendation, or favoring of the same by WSMS, WSRC, DOE or their respective officers, directors, employees, agents, consultants or personal services contractors. The views and opinions of the authors expressed herein do not necessarily state or reflect those of the United States Government or any agency thereof. 
This document was prepared in conjunction with work accomplished under Contract No.

DE-AC09-96SR18500 with the U.S. Department of Energy.

\section{DISCLAIMER}

This report was prepared as an account of work sponsored by an agency of the United States Government. Neither the United States Government nor any agency thereof, nor any of their employees, makes any warranty, express or implied, or assumes any legal liability or responsibility for the accuracy, completeness, or usefulness of any information, apparatus, product or process disclosed, or represents that its use would not infringe privately owned rights. Reference herein to any specific commercial product, process or service by trade name, trademark, manufacturer, or otherwise does not necessarily constitute or imply its endorsement, recommendation, or favoring by the United States Government or any agency

thereof. The views and opinions of authors expressed herein do not necessarily state or reflect those of the United States Government or any agency thereof.

This report has been reproduced directly from the best available copy.

Available for sale to the public, in paper, from: U.S. Department of Commerce, National Technical Information Service, 5285 Port Royal Road, Springfield, VA 22161, phone: (800)

553-6847, fax: (703) 605-6900, email: orders@ntis.fedworld.gov online ordering: http://www.ntis.gov/ordering.htm

Available electronically at http://www.doe.gov/bridge

Available for a processing fee to U.S. Department of Energy and its contractors, in paper, from: U.S. Department of Energy, Office of Scientific and Technical Information, P.O. Box 62, Oak Ridge, TN 37831-0062, phone: (865 ) 576-8401, fax: (865) 576-5728, email: reports@ adonis.osti.gov 


\section{APPROVALS}

Author/Technical Reviewer:

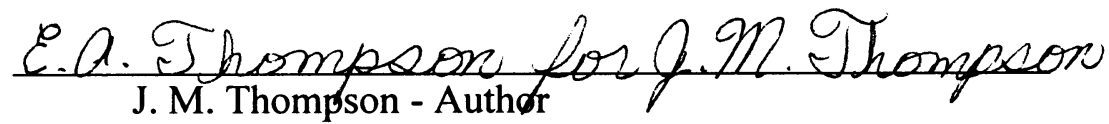

C.a. Thompson

E. A. Thompson - Author

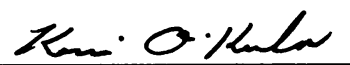

K. R. O’Kula - Technical Reviewer

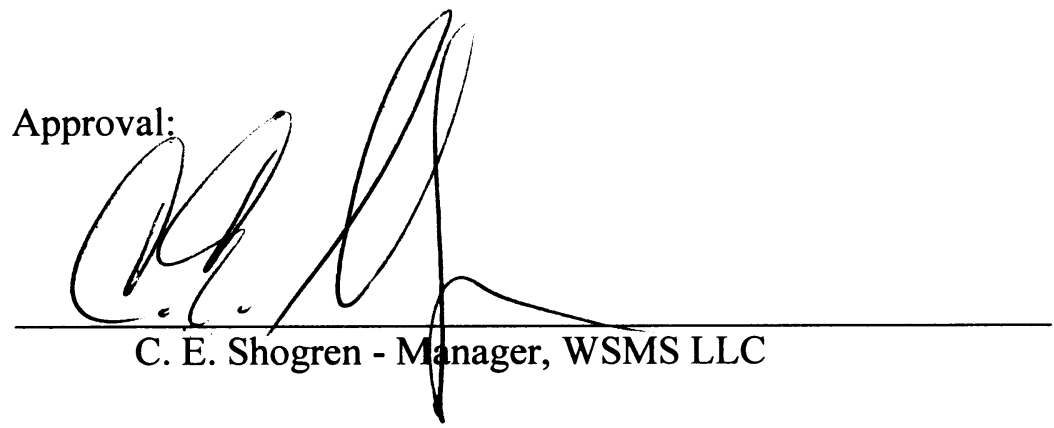

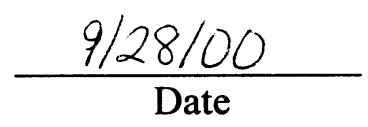
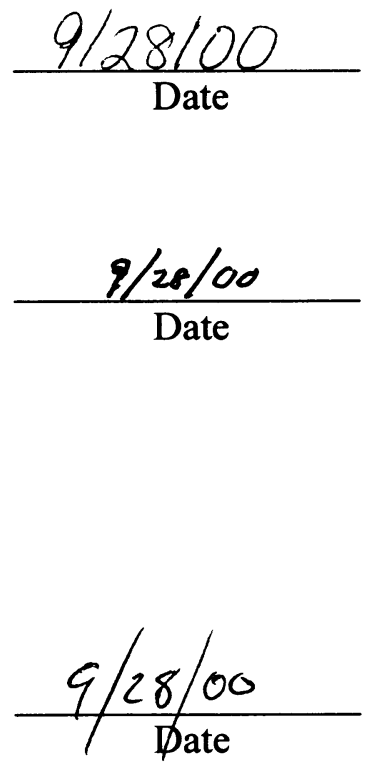


\section{ABSTRACT}

This manual documents a recommended methodology for determining the ingestion pathway consequences of hypothetical accidental airborne radiological releases from facilities at the Savannah River Site. Both particulate and tritiated radioactive contaminants are addressed. Other approaches should be applied for evaluation of routine releases. 


\section{TABLE OF CONTENTS}

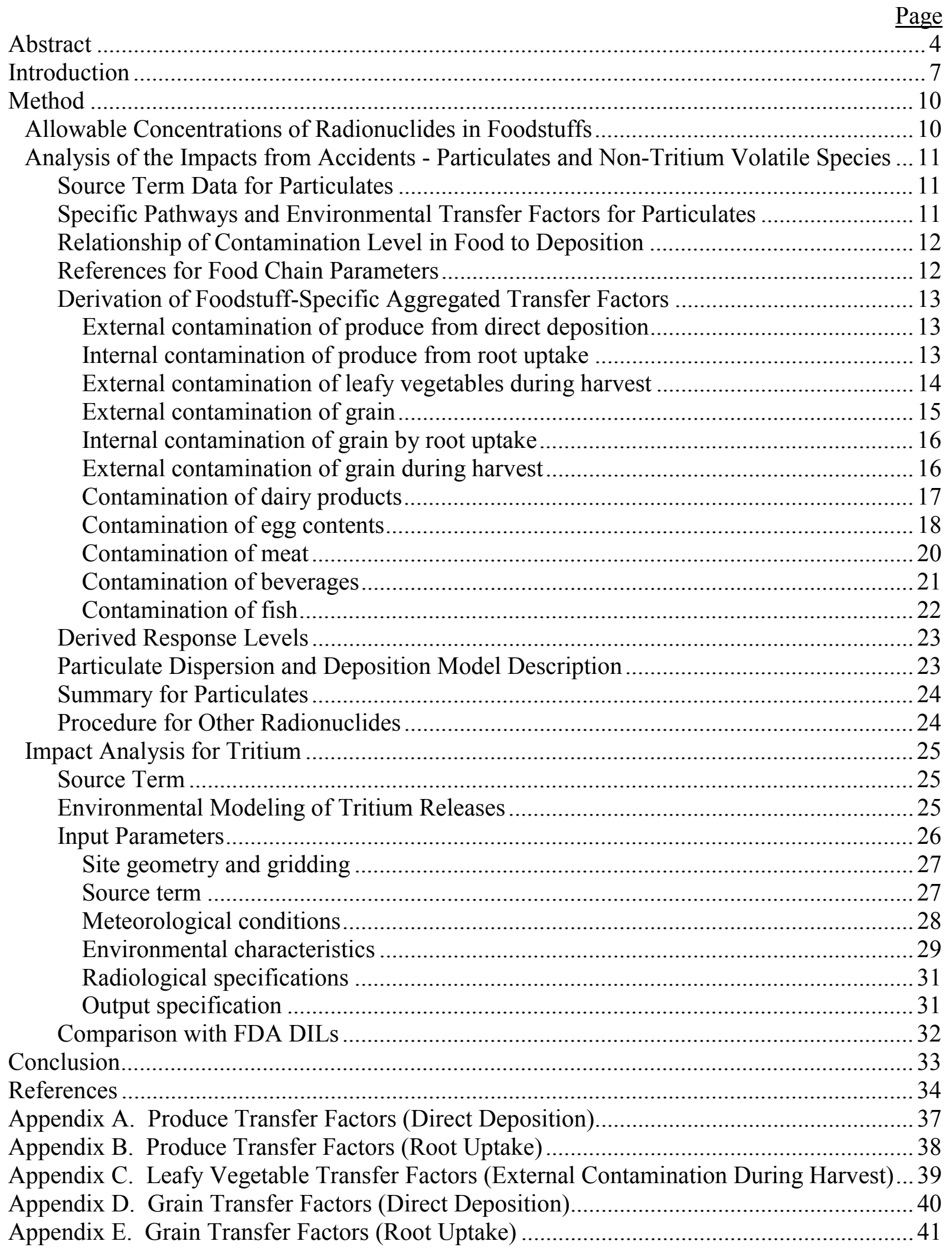


Appendix F. Grain Transfer Factors (External Contamination During Harvest)..................... 42

Appendix G. Dairy Product Transfer Factors ........................................................................ 43

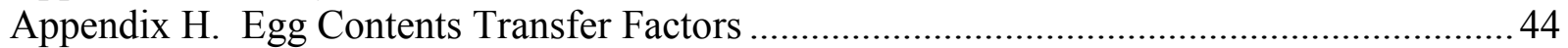

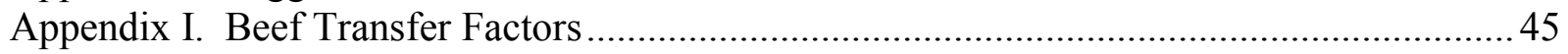

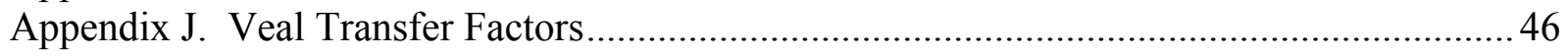

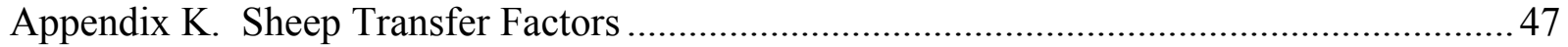

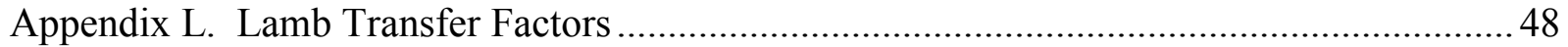

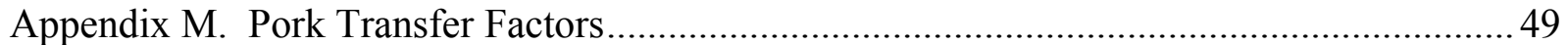

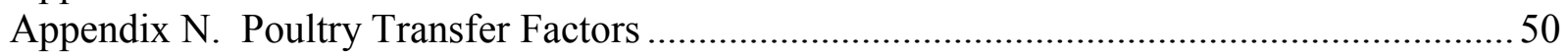

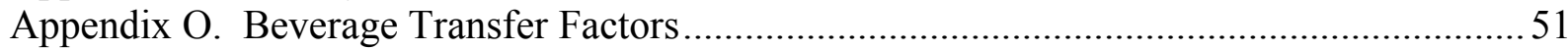

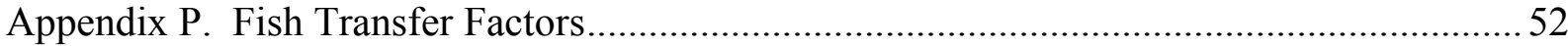

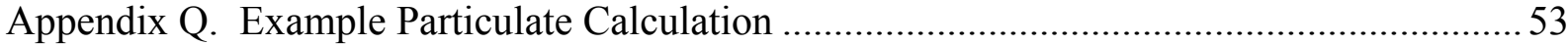

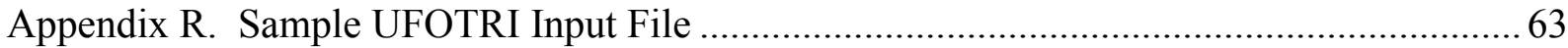




\section{Savannah River Site Ingestion Pathway Methodology Manual for Airborne Radioactive Releases}

\section{INTRODUCTION}

For emergency planning and potential food interdiction decision-making, it may be desirable to assess the ingestion pathway consequences of hypothetical accidents at various nuclear facilities. The ingestion pathway consequences of a single accident at each of three facilities were assessed previously. This manual describes the recommended method to be applied for the Savannah River Site (SRS) to predict the impact of an accidental airborne release of radioactive material on the use of foodstuffs downwind of such a release.

Department of Energy (DOE) emergency management guidance (DOE 1997) establishes requirements for assessing the consequences of postulated accidents at DOE sites. These requirements are used as bases for the assessments described in this manual.

The new Food and Drug Administration (FDA) recommendations for the accidental radioactive contamination of human foods and animal feeds (FDA 1998) provide the basis for the evaluation of ingestion pathway consequences.

The overall approach used to evaluate the impact of an atmospheric release of radionuclides on the food chain may be divided into several steps that follow radioactive material through the environment and food chain to humans. Table 1 was adapted from NCRP-50, Environmental Radiation Measurements (NCRP 1976). This table illustrates the steps from release of radionuclides into the environment to the dose that results from human ingestion. It also identifies two physical quantities (identified by shaded areas following the pathway step) that could be measured and compared to limits.

The form of the radioactive material released into the air may be particulate, vapor, or gas. Particulates include most substances that may be released, such as transuranics. Tritium may be released into the air in the oxide form (e.g., HTO, DTO, and $\mathrm{T}_{2} \mathrm{O}$ vapor) or as an elemental gas (HT, DT, and $\mathrm{T}_{2}$ ). Fission products include noble gases and volatile iodines. Noble gases are not a concern for the ingestion pathway, since their incorporation into the food chain is minimal.

Volatile iodines may be of concern with criticality-related accidents, or with postulated accidents involving spent fuel of very short cooling times. Since the fuel processed at SRS has generally undergone a significant cooling period and most radioiodines are short-lived, radioiodines are not expected to be major contributors to dose from ingestion. The exception may be the longlived radionuclide, I-129, which may be a significant contributor to dose and whose impact should be evaluated if it is a significant constituent of a source term. 
Table 1. Illustrative pathway for internal radiation exposure from airborne radionuclide effluent (adapted from NCRP 1976)

\begin{tabular}{|c|c|c|}
\hline Pathway Step & Variable & Product of Variables \\
\hline Source & Source term (Q) & $\begin{array}{l}\text { Radioactive material released } \\
\text { (Bq) }\end{array}$ \\
\hline Dispersion & Dispersion $(\chi / Q)$ & 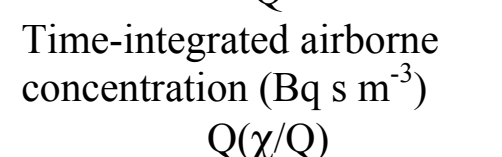 \\
\hline Cumulative Deposition & Deposition velocity $\left(\mathrm{V}_{\mathrm{d}}\right)$ & $\begin{array}{l}\text { Radioactive material per unit } \\
\text { area }\left(\mathrm{Bq} \mathrm{m}^{-2}\right) \\
\qquad \mathrm{Q}(\chi / \mathrm{Q}) \mathrm{V}_{\mathrm{d}}\end{array}$ \\
\hline \multicolumn{3}{|c|}{ (Comparison basis for particulates: deposition) } \\
\hline $\begin{array}{l}\text { Environmental and } \\
\text { Biological Transfer }\end{array}$ & Transfer factor $\left(T_{r}\right)$ & $\begin{array}{c}\text { Radioactive material per unit } \\
\text { mass of environmental or } \\
\text { biological medium }\left(\mathrm{Bq} \mathrm{kg}^{-1}\right) \\
\mathrm{Q}(\chi / \mathrm{Q}) \mathrm{V}_{\mathrm{d}} \mathrm{T}_{\mathrm{r}}\end{array}$ \\
\hline \multicolumn{3}{|c|}{ (Comparison basis for tritium: concentration in food) } \\
\hline Human Intake & Intake rate (I) & $\begin{array}{l}\text { Radioactive material intake } \\
\text { per unit time }\left(\mathrm{Bq} \mathrm{s}^{-1}\right) \\
\qquad \mathrm{Q}(\chi / \mathrm{Q}) \mathrm{V}_{\mathrm{d}} \mathrm{T}_{\mathrm{r}} \mathrm{I}\end{array}$ \\
\hline $\begin{array}{l}\text { Human Absorbed Dose } \\
\text { Rate }\end{array}$ & $\begin{array}{l}\text { Intake rate to absorbed } \\
\text { dose rate conversion factor } \\
\text { (k) }\end{array}$ & $\begin{array}{l}\text { Absorbed dose per unit time } \\
\left(\operatorname{rad~s}^{-1}\right) \\
\quad Q(\chi / Q) V_{d} T_{r} I k\end{array}$ \\
\hline
\end{tabular}

The first pathway step describes the amount of material released to the environment. Nuclidespecific source terms are adapted from authorization basis documents and emergency preparedness hazards assessments (EPHAs) evaluating the immediate dose from plume passage. For consequence analyses when inhalation pathways are the primary concern, the respirable (aerodynamic diameters less than 10 microns) airborne release is used. For consequences involving the ingestion pathways, it is more appropriate to use the total (the sum of the respirable and nonrespirable) airborne release.

The dispersion pathway step transports the release to downwind locations. The atmospheric dispersion model chosen for a particular application depends on the problem that needs to be solved. For determining ingestion pathway consequences, a simple straight-line Gaussian model is sufficient. The background for this decision is provided in Selection of Models for Ingestion Pathway and Relocation (Thompson 1999a). A summary of the points considered in this decision is presented here.

The model should be consistent with guidance for emergency planning use. It should be among, or be consistent with, those models that will actually be used or available following a release, should allow the user to modify dispersion and deposition parameters to site-specific values, and 
should also have adequate documentation. The capabilities of a complex dispersion model may impose undue data development demands, without providing commensurate improvements in the quality of results. Additionally, for relatively flat terrain such as that characterizing the region around SRS, complex terrain models yield little added value. For these and other reasons, a simple Gaussian model is justified.

The cumulative deposition pathway step quantifies the amount of contaminant deposited on the ground (or directly on foodstuffs in some cases). To assess this effect, the concept of a deposition velocity is employed. The deposition velocity is defined to be the flux to ground divided by the air pollutant concentration (Randerson 1984). Deposition velocities can range from $\sim 0.0$ to $10 \mathrm{~cm} \mathrm{~s}^{-1}$. High deposition velocities result in more deposition close to the release point, but deplete the plume more rapidly. Small deposition velocities result in less deposition for a given airborne concentration, but may result in a greater contaminant concentration farther from the release point since the plume is depleted less rapidly. The deposition "footprint" is a complex function of deposition velocity, wind velocity, activity released, and atmospheric stability class.

Environmental and biological transfer factors relate the concentration of radionuclides in one compartment of the pathway to another. Although in Table 1 only one aggregated transfer factor is shown $\left(T_{r}\right)$, radioactive contaminants may pass through multiple compartments to reach humans. Transfer between any two adjacent compartments would be described by an individual transfer factor, and the aggregated value obtained by taking the product of the individual factors. When available, site-specific individual and aggregated transfer factors are used. Otherwise, values from other sources, as detailed later, are used. The product of the nuclide-specific aggregated transfer factor (in $\mathrm{m}^{2} \mathrm{~kg}^{-1}$ or $\mathrm{m}^{2} \mathrm{~L}^{-1}$ ) for a given pathway and nuclide-specific deposition $\left(\mathrm{Bq} \mathrm{m}^{-2}\right.$ ) gives the expected concentration of the nuclide in the foodstuff (in $\mathrm{Bq} \mathrm{kg}^{-1}$ or $\left.\mathrm{Bq} \mathrm{L}{ }^{-1}\right)$.

The aggregated transfer factor is a measure of the concentration in a particular food via a specific food pathway that results from the deposition of radionuclides. If the expected concentration in food is small per unit deposition, the aggregated transfer factor will be small. Foods with higher expected concentrations have larger aggregated transfer factors. A comparison of the aggregated transfer factors for various foodstuffs and pathways shows which pathways result in the highest concentrations in food for a given deposition.

The product of variables after applying environmental and biological transfer factors (the radioactive material per unit mass of environmental or biological medium) may be compared to Derived Intervention Levels (DILs) for food in FDA 1998. The intake rate and dose rate conversion factor in the last two rows of Table 1 are incorporated in the derivation of the DIL for each group of nuclides. The approach for tritium differs from this one because most tritium models calculate food concentrations directly. The computed tritium concentrations in food may be compared directly to DILs derived using FDA methodology.

Notwithstanding the most recent FDA guidance, it must be recognized that current DOE guidance in DOE G 151.1-1, Vol. 2, Section B.2.1, Radiological Protective Action Criteria (DOE 1997) cites the old FDA guidance. Since the new FDA guidelines were issued recently, it is 
presumed that DOE guidance will be revised to reference the new guidelines. The new FDA guidelines appear to be much more restrictive than the old guidelines. Therefore, the new FDA DILs are recommended for use as evaluation guidelines for the ingestion pathways. Discussions with DOE, the Environmental Protection Agency (EPA), and the Nuclear Regulatory Commission (NRC) have indicated the intent to use the new guidelines.

An alternative to comparing food concentrations with a DIL is to compare deposition levels with a Derived Response Level (DRL). A DRL is the deposition that results in a concentration of a DIL in a foodstuff. Since deposition values (but not food concentrations) are calculated in HOTSPOT, comparison using DRLs allows convenient use of this relatively simple dispersion code. Therefore, deposition is used to evaluate ingestion pathway consequences for particulates.

\section{METHOD}

\section{ALlOWABLE CONCENTRATIONS OF RAdiOnUCLIDES in FoOdSTUFFS}

The Food and Drug Administration (FDA) Derived Intervention Levels (DILs) are limits on the concentrations permitted in human food distributed in commerce to prevent consumption of undesirable amounts of radionuclides and apply in the first year after an accident (FDA 1998). The DIL corresponds to the concentration in food present throughout the relevant period of time that, in the absence of any intervention, could lead to an individual receiving a radiation dose equal to the Protective Action Guide (PAG). The PAGs for the ingestion pathway are 0.5 rem committed effective dose equivalent or 5 rem committed dose equivalent to an individual tissue or organ, whichever is most limiting.

FDA (1998) places selected radionuclides into five primary groups, each with common characteristics. These groups are:

- $\mathrm{Sr}-90$

- I-131

- $\mathrm{Cs}-134+\mathrm{Cs}-137$

- $\mathrm{Pu}-238+\mathrm{Pu}-239+\mathrm{Am}-241$

- $\mathrm{Ru}-103+\mathrm{Ru}-106$

The five radionuclide groups are not sufficient to cover accidents at all types of facilities or locations. Appendix E of FDA (1998) presents DILs for 15 additional radionuclides. DILs for tritiated water (HTO) and organically bound tritium (OBT) were derived using methodology consistent with FDA (1998) and are listed in Table 2 (Tharakan 1999).

Table 2. Calculated DILs for HTO and OBT

\begin{tabular}{cc}
\hline $\begin{array}{c}\text { Radionuclide } / \\
\text { Group }\end{array}$ & DIL (Ci $/ \mathrm{g})$ \\
\hline HTO & $5.9 \mathrm{E}-09$ \\
OBT & $2.4 \mathrm{E}-09$ \\
\hline
\end{tabular}




\section{ANALYSIS OF THE IMPACTS FROM ACCIDENTS - PARTICUlates AND NON-TRITIUM Volatile} SPECIES

Inputs needed for calculation of ingestion pathway impacts for particulates and non-tritium vapors are a source term, dispersion/deposition parameters, and environmental transfer factors. In the following discussion, references to particulates should be understood to apply to both particulates and non-tritium vapors.

\section{Source Term Data for Particulates}

Source term data will normally be available from authorization basis documents or EPHAs. Caution must be exercised when gathering source term data, since authorization basis documents and EPHAs usually present respirable releases, rather than total (respirable plus nonrespirable) releases. Division of the respirable source term by the respirable fraction (RF) term will give the total release.

The total release from an accident scenario may involve multiple release points and initiators (fire, spill, debris, etc.). Releases must be evaluated on a nuclide-specific basis, not using $\mathrm{Pu}$ equivalent or any similar construct. The source term may be derived to achieve the maximum release or a most likely release depending on the intent of the final calculation.

\section{Specific Pathways and Environmental Transfer Factors for Particulates}

The pathways considered for this analysis are only those that involve ingestion of foodstuffs (either liquid or solid). The food groups listed in FDA 1998 (Table D-2) are evaluated, with further breakdown when the transfer factors are available. The food intake values used in the DIL determinations were national (versus regional) values.

The following is a suggested list of dietary components:
Dairy
Egg contents
Meat
Beef
Veal
Sheep
Lamb
Pork
Poultry
Fish
Produce - direct deposition
Produce - root uptake
Produce - soil adhesion
Grain - direct deposition
Grain - root uptake
Grain - soil adhesion
Beverage (including water) 


\section{Relationship of Contamination Level in Food to Deposition}

Environmental transfer factors are used to relate deposition of radionuclides (calculated using atmospheric dispersion computer programs) to concentrations in food (for comparison to DILs set by FDA in its 1998 guidance). The general relationship between the concentration of radionuclide $\mathrm{i}$ in a foodstuff $\left(\mathrm{i}_{\mathrm{i}}\right.$ food $)$ and deposition $\left({ }_{\mathrm{i}} \mathrm{D}\right)$ is

${ }_{\mathrm{i}} \mathrm{C}_{\text {food }}={ }_{\mathrm{i}} \mathrm{T} \times{ }_{\mathrm{i}} \mathrm{D}$,

where ${ }_{\mathrm{i}} \mathrm{C}_{\text {food }}$ has units of becquerels $(\mathrm{Bq})$ per kilogram (wet weight), radionuclide-specific deposition ${ }_{\mathrm{i}} \mathrm{D}$ has units of $\mathrm{Bq}$ per square meter, and ${ }_{\mathrm{i}} \mathrm{T}$ is an aggregated transfer factor in square meters per kilogram. The aggregated transfer factor ${ }_{\mathrm{i}} \mathrm{T}$ is often the product of many individual factors, each describing transfer from one environmental compartment to another. For example, an aggregated transfer factor describes the radionuclide concentration in milk resulting from fresh deposition of radionuclides on the surface of a field. An individual transfer factor in this pathway is one relating the radionuclide intake of a cow to the concentration of that radionuclide in milk.

A small aggregated transfer factor occurs when a relatively small amount of deposited material reaches the foodstuff of concern. A large aggregated transfer factor is associated with radionuclides that transport readily from deposition on the soil to a foodstuff.

\section{References for Food Chain Parameters}

The aggregated transfer factor is often calculated by modeling the sequential movement of radionuclides from deposition on the ground to incorporation in the foodstuff (i.e., as the product of individual transfer factors). Parameters may be found in several scientific and regulatory documents. Some parameters are found in Regulatory Guide (RG) 1.109, Rev.1 (NRC 1977). Although RG 1.109 is primarily intended for assessment of routine releases, some values are applicable to acute, accidental releases. An additional source of parameters is Department of Health and Human Services (HHS) Publication FDA 82-8196, Background for Protective Action Recommendations: Accidental Radioactive Contamination of Food and Animal Feeds (Shleien and Chiacchierini 1982) which is contained within EPA (1992). Generic values for parameters have also been published in more recent documents, including Radiological Assessment (Till and Meyer 1983); IAEA Technical Reports Series No. 364, Handbook of Parameter Values for the Prediction of Radionuclide Transfer in Temperate Environments (IAEA 1994); and NCRP 123, Screening Models for Releases of Radionuclides to Atmosphere, Surface Water, and Ground (NCRP 1996). Values specific to the Savannah River Site (SRS) for some parameters may be found in WSRC-RP-91-17, Land and Water Use Characteristics in the Vicinity of the Savannah River Site (Hamby 1991), and an associated Health Physics Journal article, Site-Specific Parameter Values for the Nuclear Regulatory Commission's Food Pathway Dose Model (Hamby 1992). 


\section{Derivation of Foodstuff-Specific Aggregated Transfer Factors}

\section{External contamination of produce from direct deposition}

This pathway describes the external contamination of produce from deposition directly onto the edible portions of the plant. Contamination is present on the outer surfaces of the produce. This pathway is applicable to produce that is present in fields at the time the deposition occurs. There will be no contribution to contamination from this pathway for produce planted after plume passage (however, other pathways may be significant).

The relationship between the initial concentration in food ${ }_{\mathrm{i}} \mathrm{C}_{\text {produce, direct }}$ from direct deposition of radionuclide $\mathrm{i}\left({ }_{\mathrm{i}} \mathrm{D}\right)$ on produce, following an acute release, is

${ }_{i} C_{\text {produce, direct }}=\left(\mathrm{r} / \mathrm{Y}_{\mathrm{v}}\right) \times{ }_{\mathrm{i}} \mathrm{D}$

No credit is taken for reduction in radionuclide concentration due to weathering.

The interception fraction $r$ corrects for the difference in total amount of material deposited and that which deposits on edible portions of produce. The agricultural productivity, or yield, $Y_{v}$ is the wet weight of produce growing per unit area. The SRS-specific yield (wet weight) for leafy vegetables, $Y_{v}$, is given as $0.7 \mathrm{~kg} \mathrm{~m}^{-2}$ per Hamby (1991), Table 2, page 13. The interception fraction, $r$, is 0.2 for particulates (RG 1.109 page 1.109-68). These values give an aggregated transfer factor for this pathway of

${ }_{\mathrm{i}} \mathrm{T}_{\text {produce, direct }}={ }_{\mathrm{i}} \mathrm{C}_{\text {produce, direct }} /{ }_{\mathrm{i}} \mathrm{D}=\mathrm{r} / \mathrm{Y}_{\mathrm{v}}=2.9 \times 10^{-1} \mathrm{~m}^{2} \mathrm{~kg}^{-1}$

This value of the transfer factor is applicable to any particulate radionuclide, since the transfer information conveyed through this term is independent of the environmental contaminant.

Coefficients and aggregated transfer factors are presented in Appendix A for many particulate radionuclides potentially found in postulated source terms from SRS facilities.

\section{Internal contamination of produce from root uptake}

This pathway models the root uptake of radionuclides by produce grown in contaminated soil. Radionuclides are drawn out of the soil and incorporated into the edible portions of the plant as it grows.

The soil-to-plant transfer factors, which are expressed as concentration ratios, ${ }_{i} \mathrm{CR}_{\text {soil to plant, dry }}(\mathrm{Bq}$ per dry weight crop / Bq per dry weight soil) are presented in Table VI of IAEA (1994), pages 17 to 25 . The category of mixed green vegetables is chosen. For vegetables, conversion of a concentration ratio based on dry weight to a ratio based on wet weight may be accomplished by dividing the dry weight concentration ratio by a factor of seven (the ratio of wet weight to dry weight), per IAEA (1994), page 26. 
An additional step is necessary to convert soil concentration (activity per unit volume) to deposition on soil (activity per unit area). The concentration ratios in Table VI of IAEA (1994) are based on a soil depth of $0.20 \mathrm{~m}$ for crops and $0.10 \mathrm{~m}$ for pasture, per IAEA (1994), page 16 . A default soil density of $1400 \mathrm{~kg} \mathrm{~m}^{-3}$ is used per IAEA (1994), page 29. The product of the soil density and soil depth gives the soil areal density. For crops, this is $280 \mathrm{~kg} \mathrm{~m}^{-2}$. For comparison, RG 1.109, page 1.109-68, recommends a default soil areal concentration value of $240 \mathrm{~kg} \mathrm{~m}^{-2}$, consistent with Till and Meyer (1983), page 5-29. This factor is the product of the soil density $\left(1600 \mathrm{~kg} \mathrm{~m}^{-3}\right)$ and depth of the root zone $(0.15 \mathrm{~m})$. A value of $280 \mathrm{~kg} \mathrm{~m}^{-2}$ is used in conjunction with the concentration ratios from Table VI of IAEA (1994).

A deposition of ${ }_{\mathrm{i}} \mathrm{D} \mathrm{Bq} \mathrm{\textrm {m } ^ { - 2 }}$ of a radionuclide results in a concentration of $\left({ }_{\mathrm{i}} \mathrm{D} / 280\right) \mathrm{Bq} \mathrm{kg}^{-1}$ in the soil of the root zone. The relationship between the deposition and food concentration due to uptake by leafy vegetables of radionuclide $i$ from the soil is

$$
\begin{aligned}
\mathrm{i}_{\mathrm{C}} \mathrm{C}_{\text {soil uptake, produce }} & =\left({ }_{\mathrm{i}} \mathrm{CR}_{\text {soil to plant, } \mathrm{dry}} / 7\right) \times\left({ }_{\mathrm{i}} \mathrm{D} / 280\right) \\
& =\left({ }_{\mathrm{i}} \mathrm{CR}_{\text {soil to plant, } \mathrm{dry}}\right) \times\left({ }_{\mathrm{i}} \mathrm{D}\right) / 1960
\end{aligned}
$$

By rearranging Equation 1 and substituting, it can be shown that the aggregated transfer factor $\left(\mathrm{i}_{\text {soil uptake, produce }}\right.$ ) that relates deposition $\left({ }_{\mathrm{i}} \mathrm{D}\right)$ to the concentration of radionuclide $\mathrm{i}$ in leafy vegetables $\left(\mathrm{C}_{\text {soil uptake, produce }}\right)$ is

${ }_{\mathrm{i}} \mathrm{T}_{\text {soil uptake, produce }}={ }_{\mathrm{i}} \mathrm{C}_{\text {soil uptake, produce }} /{ }_{\mathrm{i}} \mathrm{D}=\left\{{ }_{\mathrm{i}} \mathrm{CR}_{\text {soil to plant, } \text { dry }} / 1960\right\} \mathrm{m}^{2} \mathrm{~kg}^{-1}$

Aggregated transfer factors will vary with soil-to-plant transfer factors $\left(\mathrm{CR}_{\mathrm{i}} \mathrm{Roil}_{\text {to }}\right.$ plant, dry $)$ for different elements or chemical forms.

Coefficients and aggregated transfer factors are presented in Appendix B for many particulate radionuclides potentially found in postulated source terms from SRS facilities.

\section{External contamination of leafy vegetables during harvest}

Resuspension and soil adhesion are processes that result in external contamination of the food product during harvest. It may be significant after weathering has reduced the amount of material deposited initially on the plant to negligible levels. An estimate of external contamination of leafy vegetables is 10 grams of soil per kilogram (dry weight) harvested (IAEA (1994), Table VII, page 27). Washing or other processing may reduce this amount. It is necessary to express the soil adhesion fraction in terms of wet weight harvested. This adjustment may be made using the wet-to-dry weight ratio of seven. The relationship between the concentration in food and deposition for this pathway, assuming a soil areal density of $280 \mathrm{~kg} \mathrm{~m}^{-2}$, is

$$
\begin{aligned}
& { }_{\mathrm{i}} \mathrm{C}_{\text {adhesion, produce }}=(1 \mathrm{dry} \mathrm{kg} / 7 \text { wet kg }) \times\left(10 \mathrm{~g} \text { soil } / 1000 \mathrm{~g} \text { dry produce } \times\left({ }_{\mathrm{i}} \mathrm{D} / 280\right)\right. \\
& { }_{\mathrm{i}} \mathrm{C}_{\text {adhesion, }} \text { produce } \\
& =5.1 \times 10^{-6} \mathrm{~m}^{2} \mathrm{~kg}^{-1} \times{ }_{\mathrm{i}} \mathrm{D}
\end{aligned}
$$


${ }_{\mathrm{i}} \mathrm{T}_{\text {adhesion, produce }}={ }_{\mathrm{i}} \mathrm{C}_{\text {adhesion, produce }} /{ }_{\mathrm{i}} \mathrm{D}=5.1 \times 10^{-6} \mathrm{~m}^{2} \mathrm{~kg}^{-1}$

This value of the transfer factor is applicable to any particulate, since it is independent of radionuclide species.

Soil adhesion and root uptake represent long-term processes that may affect crops over several growing seasons. In contrast, the direct deposition pathway is significant only for crops present during cloud passage.

Coefficients and aggregated transfer factors are presented in Appendix $\mathrm{C}$ for many particulate radionuclides potentially found in postulated source terms from SRS facilities.

\section{External contamination of grain}

This pathway describes the external contamination of grain from deposition directly onto the edible portions of the plant. Contamination is present on the outer surfaces of the grain. This pathway is applicable to grain that is present in fields at the time the deposition occurs. There will be no contribution to contamination from this pathway for grain planted after the time of direct deposition (however, other pathways may be significant).

The relationship between direct deposition and food contamination ( $\mathrm{Bq} \mathrm{kg}^{-1}$ wet weight) for the consumption of externally contaminated grain may be calculated in a manner similar to that for produce. The crop yield $\left(\mathrm{kg}\right.$ wet weight $\mathrm{m}^{-2}$ ) and interception fraction are needed. A crop yield value is not given specifically for grain in RG 1.109 or Hamby (1991). Assuming the yield of grain is the same as produce, the yield, $Y_{v}$, is given as 0.7 (wet) $\mathrm{kg} \mathrm{m}^{-2}$ in Hamby (1991), Table 2, page 13. The interception fraction, $r$, is 0.2 for particulates ( $R G 1.109$, page 1.109-68).

The relationship between the concentration in food and deposition for direct deposition on grain is

$\mathrm{C}_{\text {grain, direct }}=\left(\mathrm{r} / \mathrm{Y}_{\mathrm{v}}\right) \times{ }_{\mathrm{i}} \mathrm{D}$

$$
=2.9 \times 10^{-1} \mathrm{~m}^{2} \mathrm{~kg}^{-1} \times{ }_{\mathrm{i}} \mathrm{D}
$$

${ }_{\mathrm{i}} \mathrm{T}_{\text {grain, direct }}={ }_{\mathrm{i}} \mathrm{C}_{\text {grain, direct }} /{ }_{\mathrm{i}} \mathrm{D}=2.9 \times 10^{-1} \mathrm{~m}^{2} \mathrm{~kg}^{-1}$

This value of the aggregated transfer factor is applicable to any particulate, since it is independent of radionuclide species. This value is the same as for leafy vegetables since interception fractions and yields are the same. The value for the aggregated transfer factor $\left(\mathrm{T}_{\text {grain, direct }}\right)$ is probably very conservative (high) since the edible parts of cereals are often less exposed than the edible parts of leafy vegetables.

Coefficients and aggregated transfer factors are presented in Appendix D for many particulate radionuclides potentially found in postulated source terms from SRS facilities. 


\section{Internal contamination of grain by root uptake}

This pathway models the root uptake of radionuclides by grain grown in contaminated soil. Radionuclides are drawn out of the soil and incorporated into the edible portions of the plant as it grows.

The soil-to-plant transfer factors ${ }_{\mathrm{i}} \mathrm{CR}_{\text {soil to plant, dry }}$ (Bq per dry weight crop / Bq per dry weight soil) are presented in Table VI of IAEA (1994), pages 17 to 25 . The category "cereals" is chosen for grain. Dry weight contents of cereals are presented in Table V, page 15, of IAEA (1994). The average dry weight content of cereals is about $86 \%$. This value is consistent with the grains class average in Table 5.16, page 5-48, of Till and Meyer (1983). Each dry weightbased transfer factor must be multiplied by the dry weight content, since concentrations in food calculated here are based on wet food weight.

An areal concentration value of $280 \mathrm{~kg} \mathrm{~m}^{-2}$ is assumed.

The relationship between deposition and the concentration in grain due to root uptake of the $i^{\text {th }}$ radionuclide from the soil is

$$
\begin{aligned}
{ }_{\mathrm{i}} \mathrm{C}_{\text {soil uptake, grain }} & =\left(\mathrm{i}_{\mathrm{i}} \mathrm{CR}_{\text {soil to plant, dry }} \times 0.86\right) \times\left({ }_{\mathrm{i}} \mathrm{D} / 280\right) \\
& \left.=\left({ }_{\mathrm{i}} \mathrm{CR}_{\text {soil to plant, dry }} \times{ }_{\mathrm{i}} \mathrm{D}\right) / 326\right)
\end{aligned}
$$

The overall transfer factor, for the $\mathrm{i}^{\text {th }}$ radionuclide, for this pathway is given by

${ }_{\mathrm{i}} \mathrm{T}_{\text {soil uptake, grain }}={ }_{\mathrm{i}} \mathrm{CR}_{\text {soil to plant, } \text { dry }} / 326 \mathrm{~m}^{2} \mathrm{~kg}^{-1}$

Coefficients and aggregated transfer factors are presented in Appendix E for many particulate radionuclides potentially found in postulated source terms from SRS facilities.

\section{External contamination of grain during harvest}

Resuspension and soil adhesion are processes that result in external contamination of the food product during harvest. It may be significant after weathering has reduced the amount of material deposited initially on the plant to negligible levels. An estimate of external contamination of grain is 4 grams of soil per kilogram (dry weight) harvested (IAEA (1994) Table VII, page 27). Washing or other processing may reduce this amount. It is necessary to express the soil adhesion fraction in terms of wet weight harvested. This adjustment may be made using the dry weight content of 0.86 dry weight/wet weight. The relationship between the concentration in food and deposition for this pathway, assuming a soil areal density of $280 \mathrm{~kg} \mathrm{~m}^{-2}$, is

$$
\begin{aligned}
{ }_{\mathrm{i}} \mathrm{C}_{\text {adhesion, grain }} & =[(0.86 \text { dry } / \text { wet })(4 \mathrm{~g} \text { soil } / 1000 \mathrm{~g} \text { dry grain })] \times{ }_{\mathrm{i}} \mathrm{D} / 280 \mathrm{~kg} \mathrm{~m}^{-2} \\
& =1.2 \times 10^{-5} \mathrm{~m}^{2} \mathrm{~kg}^{-1} \times{ }_{\mathrm{i}} \mathrm{D} \\
{ }_{\mathrm{i}} \mathrm{T}_{\text {adhesion, grain }}= & { }_{\mathrm{i}} \mathrm{C}_{\text {adhesion, grain }} /{ }_{\mathrm{i}} \mathrm{D}=1.2 \times 10^{-5} \mathrm{~m}^{2} \mathrm{~kg}^{-1}
\end{aligned}
$$


This value of the aggregated transfer factor is applicable to any particulate, since it is independent of radionuclide species.

Coefficients and aggregated transfer factors are presented in Appendix $\mathrm{F}$ for many particulate radionuclides potentially found in postulated source terms from SRS facilities.

\section{Contamination of dairy products}

The milk pathway is assumed to characterize pathways for all dairy products. This pathway describes the concentration in milk resulting from fresh deposition. Different calculations are necessary to describe long-term effects, since the concentrations of radionuclides associated with forage are expected to decrease as time after deposition increases.

The milk pathway is described by a two-step process. Deposition contaminates forage, then the forage is consumed by cows and contaminated milk is produced. The amount of external contamination on forage due to direct deposition of radionuclide $i$ is

${ }_{i} C_{\text {forage, direct }}=\left(r / Y_{v}\right) \times{ }_{i} D$

The fraction of deposition initially retained on pasture grass, $r$, is 0.2 for chronic releases (RG 1.109, page 1.109-68). A deposition fraction of 0.5 is given on page 13 of Shleien and Chiacchierini (1982), and is adopted as the value for pasture following an acute release of particulates in the following calculation. The SRS-specific agricultural productivity per unit area (measured in wet weight) $\left(Y_{\mathrm{v}}\right)$ for the grass-cow-milk pathway is $1.8 \mathrm{~kg} \mathrm{~m}^{-2}$ (Hamby 1991). This is somewhat greater than the generic value for agricultural productivity for this pathway of $0.7 \mathrm{~kg} \mathrm{~m}^{-2}$ (RG 1.109, page 1.109-69). The SRS-specific value is used in the following calculations.

Equation C-10 of RG 1.109, page 1.109-27, provides a means to estimate the radionuclide concentration in milk $\left(\mathrm{C}_{\mathrm{i}}^{\mathrm{m}}\right)$ if the contamination level of feed is known:

${ }_{\mathrm{i}} \mathrm{C}^{\mathrm{m}}={ }_{\mathrm{i}} \mathrm{F}^{\mathrm{m}} \times{ }_{\mathrm{i}} \mathrm{C}^{\mathrm{v}} \times \mathrm{Q}_{\mathrm{F}} \times \exp \left(-\lambda_{\mathrm{i}} \times \mathrm{t}_{\mathrm{f}}\right)$

where,

${ }_{i} \mathrm{~F}^{\mathrm{m}}$ is the average fraction of a cow's daily intake of radionuclide $\mathrm{i}$ that appears in each liter of milk. ${ }_{i} F^{\mathrm{m}}$ has units of $\mathrm{Bq} \mathrm{L}^{-1}$ of milk per $\mathrm{Bq}$ day $^{-1}$ consumed by the cow, or $\mathrm{d} \mathrm{L}^{-1}$.

${ }_{\mathrm{i}} \mathrm{C}^{\mathrm{v}}$ is the concentration of radionuclide $\mathrm{i}$ in the cow's feed, with units of $\mathrm{Bq} \mathrm{kg}^{-1}$ (wet weight). Feed may be either pasture grass (contaminated forage) or stored feed (assumed uncontaminated). ${ }_{i} \mathrm{C}^{\mathrm{v}}$ is set equal to ${ }_{\mathrm{i}} \mathrm{C}_{\text {forage, direct }}$ for contaminated forage.

$\mathrm{Q}_{\mathrm{F}}$ is the amount of contaminated feed consumed by the cow per day. It should be expressed in terms of wet weight, since the contamination level of forage is also in wet weight. The total consumption rate (wet weight per day) of forage consumed by a dairy 
cow is $52 \mathrm{~kg} \mathrm{~d}^{-1}$ (Hamby 1991). The SRS-specific fraction of intake from pasture is 0.56 (Hamby 1991). The product of these factors results in a daily consumption rate of contaminated forage $\left(Q_{F}\right)$ of $29.12 \mathrm{~kg} \mathrm{~d}^{-1}$.

$\lambda_{\mathrm{i}}$ is the radiological decay constant for the $\mathrm{i}^{\text {th }}$ radionuclide in units of days ${ }^{-1}$.

$\mathrm{t}_{\mathrm{f}}$, the time to market, is a time factor that combines the time required to get activity from the feed into the milk and the milk to the receptor.

Equation 19 is for chronic intake by the cow and represents an upper bound to the acute case if deposition levels immediately after the accident are used to calculate contamination on forage. Contamination levels would be expected to decrease over time due to weathering, resulting in lower concentrations of radionuclides in milk following the initial peak.

The argument of the exponential factor is the product of the decay constant for radionuclide $i$ and the time to market $\left(\mathrm{t}_{\mathrm{f}}\right)$. The decay constants for radionuclides of concern are very small. Time to market is usually taken as 2 days (RG 1.109, page 1.109-27). The product of the decay constant and time to market is about 0 , resulting in the exponential term having a value of about one. For long-lived radionuclides, the exponential term can be set equal to unity.

The simplified equation is now

${ }_{\mathrm{i}} \mathrm{C}^{\mathrm{m}}={ }_{\mathrm{i}} \mathrm{F}^{\mathrm{m}} \times{ }_{\mathrm{i}} \mathrm{C}_{\text {forage, direct }} \times \mathrm{Q}_{\mathrm{F}}$

Substituting in the expression for ${ }_{\mathrm{i}} \mathrm{C}_{\text {forage, direct }}$ from Equation 18 into Equation 20 gives

${ }_{i} \mathrm{C}^{\mathrm{m}}={ }_{\mathrm{i}} \mathrm{F}^{\mathrm{m}} \times\left(\mathrm{r} / \mathrm{Y}_{\mathrm{v}}\right) \times{ }_{\mathrm{i}} \mathrm{D} \times \mathrm{Q}_{\mathrm{F}}$

The aggregated transfer factor ${ }_{i} \mathrm{~T}^{\mathrm{m}}$ for the milk pathway from direct deposition of the $\mathrm{i}^{\text {th }}$ radionuclide is therefore

${ }_{\mathrm{i}} \mathrm{T}^{\mathrm{m}}={ }_{\mathrm{i}} \mathrm{C}^{\mathrm{m}} /{ }_{\mathrm{i}} \mathrm{D}={ }_{\mathrm{i}} \mathrm{F}^{\mathrm{m}} \times\left(\mathrm{r} / \mathrm{Y}_{\mathrm{v}}\right) \times \mathrm{Q}_{\mathrm{F}}$

Since milk has a density of $1 \mathrm{~kg} \mathrm{~L}^{-1}$, the aggregated transfer factor is numerically equivalent whether expressed in units of $\mathrm{m}^{2} \mathrm{~L}^{-1}$ or $\mathrm{m}^{2} \mathrm{~kg}^{-1}$.

Coefficients and aggregated transfer factors are presented in Appendix $\mathrm{G}$ for many particulate radionuclides potentially found in postulated source terms from SRS facilities.

\section{Contamination of egg contents}

Chicken eggs may become contaminated due to hens consuming radionuclides in feed. Since only the egg contents are consumed, radionuclides in the shell are not included. 
The relationship between the concentration of long-lived radionuclide $\mathrm{i}$ in egg contents in $\mathrm{Bq} \mathrm{kg}^{-1}\left(\mathrm{i}_{\mathrm{C}}^{\mathrm{e}}\right)$, and the amount of contaminated feed consumed per day is similar to the relationship for contaminated forage and level of radionuclides in milk:

${ }_{i} \mathrm{C}^{\mathrm{e}}={ }_{\mathrm{i}} \mathrm{F}^{\mathrm{e}} \times{ }_{\mathrm{i}} \mathrm{C}^{\mathrm{v}} \times \mathrm{Q}_{\mathrm{F}}$

${ }_{i} \mathrm{~F}^{\mathrm{e}}$ is the average fraction of a laying hen's daily intake of radionuclide $\mathrm{i}$ that appears in each kilogram of egg contents. ${ }_{i} \mathrm{~F}^{\mathrm{e}}$ has units of $\mathrm{Bq} \mathrm{kg}^{-1}$ of egg contents per $\mathrm{Bq}$ day ${ }^{-1}$ consumed by the laying hen, or $\mathrm{dg}^{-1}$.

${ }_{i} \mathrm{C}^{\mathrm{v}}$ is the concentration of radionuclide $\mathrm{i}$ in the laying hen's feed, with units of $\mathrm{Bq} \mathrm{kg}$ (wet weight). The typical feedstuffs are cereals and protein feed (IAEA (1994), Table X, page 32). If the entire diet is assumed to consist of grain contaminated by fresh deposition, the parameters from the section on externally contaminated grain may be used. The conservative assumption is made that all of the laying hens' feed is from contaminated grain. ${ }_{i} \mathrm{C}^{\mathrm{V}}$ is set equal to ${ }_{i} \mathrm{C}_{\text {grain, }}$ direct.

The concentration of radionuclide i resulting from direct deposition onto grain is

${ }_{\mathrm{i}} \mathrm{C}_{\text {grain, }}$ direct $=\left(\mathrm{r} / \mathrm{Y}_{\mathrm{v}}\right) \times{ }_{\mathrm{i}} \mathrm{D}$

$\mathrm{Q}_{\mathrm{F}}$ is the amount of feed consumed by the hen per day. It should be expressed in terms of wet weight, since the contamination level of grain is also in wet weight. Laying hens have a consumption rate of dry matter of $0.1 \mathrm{~kg} \mathrm{~d}^{-1}$ (IAEA (1994) Table XI, page 33). Dry weight contents of cereals (assumed to be representative of grain) are presented in IAEA (1994), Table V, page 15 . The average dry weight content of cereals is about $86 \%$, so the wet consumption rate is $\left(0.1 \mathrm{~kg} \mathrm{~d}^{-1} / 0.86\right)=0.116 \mathrm{~kg} \mathrm{~d}^{-1}$.

The relationship between the concentration in eggs and deposition may be estimated by combining Equation 23 and Equation 24.

$$
\begin{aligned}
{ }_{\mathrm{i}} \mathrm{C}^{\mathrm{e}} & ={ }_{\mathrm{i}} \mathrm{F}^{\mathrm{e}} \times{ }_{\mathrm{i}} \mathrm{C}_{\text {grain, direct }} \times \mathrm{Q}_{\mathrm{F}} \\
& ={ }_{\mathrm{i}} \mathrm{F}^{\mathrm{e}} \times \mathrm{r} / \mathrm{Y}_{\mathrm{v}} \times{ }_{\mathrm{i}} \mathrm{D} \times \mathrm{Q}_{\mathrm{F}}
\end{aligned}
$$

The aggregated transfer factor for nuclide $\mathrm{i}$ is

${ }_{i} T^{e}={ }_{i} C^{e} / D_{i}={ }_{i} F^{e} \times\left(r / Y_{v}\right) \times Q_{F}$

A yield (wet) of $0.7 \mathrm{~kg} \mathrm{~m}^{-2}$ and an interception fraction $\mathrm{r}$ of 0.2 are assumed.

Coefficients and aggregated transfer factors are presented in Appendix $\mathrm{H}$ for many particulate radionuclides potentially found in postulated source terms from SRS facilities. 


\section{Contamination of meat}

This pathway describes the level of contamination in meat due to consumption of forage contaminated by fresh deposition. Contamination levels in meat should decrease over time as the contamination level in forage decreases. Meats considered are beef, veal, sheep, lamb, pork, and poultry.

The concentration of radionuclides in meat $\left({ }_{i} \mathrm{C}^{\mathrm{F}}\right)$ is dependent on the consumption rate of forage by the animal and the contamination level of the forage. Equation C-12 of RG 1.109, page $1.109-28$, is

${ }_{i} \mathrm{C}^{\mathrm{F}}={ }_{\mathrm{i}} \mathrm{F}^{\mathrm{f}} \times{ }_{\mathrm{i}} \mathrm{C}^{\mathrm{v}} \times \mathrm{Q}_{\mathrm{F}} \times \exp \left(-\lambda_{\mathrm{i}} \times \mathrm{t}_{\mathrm{s}}\right)$

As in the analysis for the milk pathway, the exponential term may be set equal to unity for longlived radionuclides ( $t_{s}$, the time to slaughter, is 20 days; $\lambda_{i}$ is very close to zero for long-lived radionuclides; the product of the two terms is essentially zero). The simplified equation is

${ }_{i} \mathrm{C}^{\mathrm{F}}={ }_{\mathrm{i}} \mathrm{F}^{\mathrm{f}} \times{ }_{\mathrm{i}} \mathrm{C}^{\mathrm{v}} \times \mathrm{Q}_{\mathrm{F}}$

where,

${ }_{i} \mathrm{~F}^{\mathrm{f}}$ is the fraction of daily intake by the animal of radionuclide $\mathrm{i}$ that appears in the edible flesh. It has units of $\mathrm{Bq} \mathrm{kg}^{-1}$ of meat per $\mathrm{Bq} \mathrm{d}^{-1}$ consumed by the animal, or $\mathrm{d} \mathrm{kg}^{-1}$. It varies by radionuclide and animal. Expected values may be found in IAEA (1994), Tables XV to XVIII, pages 37-39.

$\mathrm{Q}_{\mathrm{F}}$ is the amount of contaminated forage consumed by the animal per day. It should be expressed in terms of wet weight, since the contamination level of forage is also in wet weight. The site-specific total wet forage consumption rate for beef is $36 \mathrm{~kg} \mathrm{~d}^{-1}$ (Hamby 1991). As with the milk pathway, the total forage consumption rate is assumed to consist of contaminated pasture grass and uncontaminated other feed. The SRS-specific value for the fraction of intake from pasture for beef is 0.75 (Hamby 1991). The product of the total consumption rate and the fraction of intake from pasture gives a contaminated forage consumption rate of $27 \mathrm{~kg} \mathrm{~d}^{-1}$, and is presented in Table 3 . The quantities (dry weight) of forage consumed by other animals are also presented in Table 3, and are values from IAEA (1994), Table XI, page 33. Wet forage consumption rates are 4.5 times the dry consumption rates per Table 5.16, page 5-48 of Till and Meyer (1983). For meat pathways other than beef, all forage consumed by the animal is assumed to be contaminated.

${ }_{\mathrm{i}} \mathrm{C}^{\mathrm{v}}$ is the concentration of radionuclide $\mathrm{i}$ in the animal's feed, with units of $\mathrm{Bq} \mathrm{kg}^{-1}$ (wet weight). Feed is assumed to be forage contaminated by direct deposition. 
Table 3: Forage consumption rates

\begin{tabular}{ccc}
\hline Meat & $\begin{array}{c}\text { Contaminated } \\
\text { forage } \\
\text { consumption rate, } \\
\text { dry kg d }^{-1}\end{array}$ & $\begin{array}{c}\text { Contaminated } \\
\text { forage } \\
\text { consumption rate, } \\
\text { wet kg d }^{-1}\end{array}$ \\
\hline Beef & - & 27 \\
Veal & 1.9 & 8.6 \\
Sheep & 1.3 & 5.9 \\
Lamb & 1.1 & 5.0 \\
Pork & 2.4 & 11 \\
Poultry & 0.07 & 0.32 \\
\hline
\end{tabular}

The equation relating concentration of radionuclide $\mathrm{i}$ in forage $\left(\mathrm{i}_{\mathrm{i}} \mathrm{C}_{\text {forage, direct }}\right)$ to the amount of radionuclide $\mathrm{i}$ deposited on the ground $\left({ }_{\mathrm{i}} \mathrm{D}\right)$ is

${ }_{i} \mathrm{C}^{\mathrm{v}}={ }_{\mathrm{i}} \mathrm{C}_{\text {forage, direct }}=\left(\mathrm{r} / \mathrm{Y}_{\mathrm{v}}\right) \times{ }_{\mathrm{i}} \mathrm{D}$

Substituting the expression for ${ }_{i} \mathrm{C}_{\text {forage, direct }}$ in Equation 30 for ${ }_{i} \mathrm{C}^{\mathrm{v}}$ in Equation 29 gives

${ }_{i} \mathrm{C}^{\mathrm{F}}={ }_{\mathrm{i}} \mathrm{F}^{\mathrm{f}} \times\left(\mathrm{r} / \mathrm{Y}_{\mathrm{v}}\right) \times{ }_{\mathrm{i}} \mathrm{D} \times \mathrm{Q}_{\mathrm{F}}$

The aggregated transfer factors for the meat pathways are

${ }_{\mathrm{i}} \mathrm{T}^{\mathrm{F}}={ }_{\mathrm{i}} \mathrm{C}^{\mathrm{F}} /{ }_{\mathrm{i}} \mathrm{D}={ }_{\mathrm{i}} \mathrm{F}^{\mathrm{f}} \times\left(\mathrm{r} / \mathrm{Y}_{\mathrm{v}}\right) \times \mathrm{Q}_{\mathrm{F}}$

The agricultural production rate $Y_{\mathrm{v}}$ is measured in wet weight. An SRS-specific value of $1.8 \mathrm{~kg} \mathrm{~m}^{-2}$ (wet weight of pasture grass per unit area) is chosen for meat calculations (Hamby 1991). An interception fraction $r$ for pasture of 0.5 is assumed as in the dairy pathway calculation.

Coefficients and aggregated transfer factors are presented in Appendices I to $\mathrm{N}$ for many particulate radionuclides potentially found in postulated source terms from SRS facilities. The transfer factors consider only the intake from direct deposition, and do not account for added intake from soil adhesion. Additional discussion can be found on page 33 of IAEA (1994).

\section{Contamination of beverages}

Drinking water is assumed to be representative of the beverage pathway.

The concentration in water is conservatively calculated by diluting instantaneously deposited activity throughout the depth of water. For insoluble contaminants, this will usually be a very conservative assumption, since particulates are expected to settle into the sediments. For a water depth (d) of 1.0 meter and density $\rho_{\mathrm{w}}$ of $1.0 \times 10^{3} \mathrm{~kg} \mathrm{~m}^{-3}$, the activity of radionuclide i per unit mass of water $\left(\mathrm{i}_{\mathrm{w}}\right)$ from a deposition $\left({ }_{\mathrm{i}} \mathrm{D}\right)$ is 
${ }_{\mathrm{i}} \mathrm{C}_{\mathrm{w}}={ }_{\mathrm{i}} \mathrm{D} /\left(\rho_{\mathrm{w}} \times \mathrm{d}\right)$

${ }_{\mathrm{i}} \mathrm{C}_{\mathrm{w}}={ }_{\mathrm{i}} \mathrm{D} /\left(1.0 \times 10^{3} \mathrm{~kg} \mathrm{~m}^{-3} \times 1.0 \mathrm{~m}\right)$

Where ${ }_{\mathrm{i}} \mathrm{C}_{\mathrm{w}}$ is in $\mathrm{Bq} \mathrm{kg}{ }^{-1}$ and ${ }_{\mathrm{i}} \mathrm{D}$ is in $\mathrm{Bq} \mathrm{m} \mathrm{m}^{-2}$. The transfer factor relating concentration in water $\left({ }_{i} \mathrm{C}_{\mathrm{w}}\right)$ to deposition $\left({ }_{\mathrm{i}} \mathrm{D}\right)$ is

$$
\begin{aligned}
{ }_{\mathrm{i}} \mathrm{T}_{\text {water }} & ={ }_{\mathrm{i}} \mathrm{C}_{\mathrm{w}} /{ }_{\mathrm{i}} \mathrm{D}=\rho_{\mathrm{w}} \times \mathrm{d} \\
& =1.0 \times 10^{-3} \mathrm{~m}^{2} \mathrm{~kg}^{-1} .
\end{aligned}
$$

The value $1.0 \times 10^{-3} \mathrm{~m}^{2} \mathrm{~kg}^{-1}$ should be considered a conservative upper bound on the aggregated transfer factor for drinking water. Sedimentation and other processes will reduce the activity in water. If deposition occurs on flowing bodies of water, the period of exposure will be small.

The value of this aggregated transfer factor is applicable to any particulate, since it is independent of radionuclide species. Additional modifications may be made if the solubility of the particulate is known.

Coefficients and aggregated transfer factors are presented in Appendix $\mathrm{O}$ for many particulate radionuclides potentially found in postulated source terms from SRS facilities.

\section{Contamination of fish}

Acute uptake in fish will be bounded by the chronic uptake. This calculation assumes fish are continuously exposed to the initial level of deposited radionuclides in water. This would occur only in stagnant bodies of water, with no settling of radionuclides into sediment. In flowing bodies of water (such as the Savannah River), waterborne concentration at a particular location would decrease rapidly over time after the initial deposition, and concentrations of radionuclides in fish would be expected to be much lower than for fish chronically exposed in stagnant bodies of water.

Given ${ }_{i} \mathrm{C}_{\mathrm{w}}$ from the calculation for drinking water, the concentration in fish is

${ }_{i} \mathrm{C}_{\text {fish }}=\mathrm{B}_{\mathrm{p}} \times{ }_{\mathrm{i}} \mathrm{C}_{\mathrm{w}}$,

Where $\mathrm{B}_{\mathrm{p}}$ is a concentration factor for edible portions of fish with an expectation value $\left(\mathrm{Bq} \mathrm{kg}^{-1}\right.$ wet weight per $\mathrm{Bq} \mathrm{L}^{-1}$ of water) given in IAEA (1994), Table XXII, page 45). The relationship between deposition and water concentration is given in Equation 34. Combining Equation 34 and Equation 37 gives

${ }_{\mathrm{i}} \mathrm{C}_{\text {fish }}=\mathrm{B}_{\mathrm{p}} \times{ }_{\mathrm{i}} \mathrm{C}_{\mathrm{w}}=\mathrm{B}_{\mathrm{p}} \times{ }_{\mathrm{i}} \mathrm{D} /\left(1.0 \times 10^{3} \mathrm{~kg} \mathrm{~m}^{-3} \times 1.0 \mathrm{~m}\right)$

The aggregated transfer factor is 
${ }_{\mathrm{i}} \mathrm{T}_{\text {fish }}={ }_{\mathrm{i}} \mathrm{C}_{\text {fish }} /{ }_{\mathrm{i}} \mathrm{D}=\mathrm{B}_{\mathrm{p}} /\left(1.0 \times 10^{3} \mathrm{~kg} \mathrm{~m}^{-3} \times 1.0 \mathrm{~m}\right)$

This value is probably too high by a factor of at least ten for many insoluble transuranic compounds that are encountered at SRS. A typical rule of thumb is that only a few percent of the deposited plutonium is available in the water; the rest is bound in the sediments. Additionally, it takes time for concentrations of radionuclides in fish to come to equilibrium.

Coefficients and aggregated transfer factors are presented in Appendix $\mathrm{P}$ for many particulate radionuclides potentially found in postulated source terms from SRS facilities.

\section{Derived Response Levels}

Derived response levels may be calculated once the mix of the total deposition (as opposed to just the deposition associated with the respirable fraction), transfer factors, and DILs are known. A unit deposition of the mix is assumed, and the resulting concentrations of radionuclides determined in foodstuffs. Division of the DILs by foodstuff concentrations that correspond to the unit deposition gives the DRLs in terms of the activity of the mix deposited per unit area. Once the DRLs are known, a suitable dispersion model is run with the DRLs set as deposition values of interest.

\section{Particulate Dispersion and Deposition Model Description}

For particulate releases, a Gaussian-based dispersion model, capable of calculating deposition from an acute release, should be adequate. Since minimizing code complexity should maximize clarity and economy, the HOTSPOT computer program (Homann 1994) is used to perform dispersion and deposition calculations for non-tritium releases. HOTSPOT incorporates a straight-line Gaussian plume model. Deposition values (DRLs) resulting in concentrations in food equal to FDA DILs may be calculated in a spreadsheet format. Deposition isopleths at which FDA DILs are exceeded may then be determined using HOTSPOT.

The meteorology parameters are chosen so that they are consistent with the Emergency Preparedness Hazards Assessment (EPHA) guidance (WSRC 1999). Adverse ( $95^{\text {th }}$ percentile) and average meteorology cases should be run. Adverse meteorology provides an indication of maximum impacts, while average meteorology provides a more typical perspective.

Meteorological parameters are presented in Table 4.

Table 4. Meteorological Input Parameters for Particulates for Average and Adverse Conditions

\begin{tabular}{|l|c|c|}
\hline Parameter & Average Met. & Adverse Met. \\
\hline Wind Speed Height & $10 \mathrm{~m}$ & $10 \mathrm{~m}$ \\
\hline Stability Class & $\mathrm{C}$ & $\mathrm{E}$ \\
\hline Wind Speed & $2.5 \mathrm{~m} / \mathrm{s}$ & $1.7 \mathrm{~m} / \mathrm{s}$ \\
\hline Inversion Layer & $500 \mathrm{~m}$ & $300 \mathrm{~m}$ \\
\hline
\end{tabular}


The 300-meter inversion layer height for adverse meteorological conditions is derived from Holzworth (1972). An inversion layer height of 200 meters has been used until recently and is in the current EPHA guidance (WSRC 1999); however, this guidance is under revision.

A surface roughness of $100 \mathrm{~cm}$ is used to model the forested terrain surrounding SRS.

Deposition values of $0.1 \mathrm{~cm} / \mathrm{s}, 1 \mathrm{~cm} / \mathrm{s}$, and $10 \mathrm{~cm} / \mathrm{s}$ are typically used.

The source geometry should be selected as appropriate for the scenario. A 3 meter by 3 meter cross-sectional area is the standard source geometry used in EPHAs (WSRC 1999).

Contour levels corresponding to DRLs are entered in the general plume routine of HOTSPOT and deposition plots produced.

An example calculation is included in Appendix Q.

\section{Summary for Particulates}

The process used to evaluate accidental releases on the ingestion pathway is outlined below.

1. Determine the source terms (radionuclide-specific and total airborne releases).

2. Calculate the concentrations of each radionuclide in foodstuffs for a unit deposition of the total (as opposed to respirable) particulate mix.

3. For radionuclides with FDA (1998) Derived Intervention Levels (DILs), divide the DIL by the foodstuff concentration from a unit deposition. The Derived Response Level, or DRL, is the deposition that gives a DIL for a specific nuclide (group) and pathway.

4. Once DRLs are determined, ranges and areas affected are predicted with the dispersion/deposition model HOTSPOT.

\section{Procedure for Other Radionuclides}

If a source term is encountered includes significant amounts of non-tritium ${ }^{1}$ radionuclides not specifically discussed or included in the Appendices A through P, the process to handle them is similar to that outlined above. First, determine whether an FDA DIL exists for the radionuclide by reviewing the radionuclides included in Tables 2 and E- 6 of the FDA guidance document (1998). If the radionuclide is included there, use the given DIL. If a DIL for the radionuclide being considered is not included in FDA (1998), it can be developed using the method outlined in Appendix D of that document. From that point, the evaluation should follow the procedure as outlined herein.

\footnotetext{
${ }^{1}$ The special case of tritium is addressed in the next section.
} 


\section{IMPACT ANALYSIS FOR TRITIUM}

For tritium releases, a dispersion and environmental transfer code that can model the incorporation of tritium into the food chain from an acute release is desirable. Tritiated water has a much greater mobility in the environment than most radionuclides. Due to this mobility, assessment of tritium releases is best done with a tritium-specific model.

\section{Source Term}

In this following discussion, tritium in its oxide form (HTO, DTO, and $\mathrm{T}_{2} \mathrm{O}$ ), unless otherwise specified, is HTO. Likewise, tritium in its elemental form (HT, DT, and $\mathrm{T}_{2}$ ) is HT. The chemical and physical behaviors of these isotopic species are similar, so differences in movement through the environment are not appreciable.

Tritium releases will usually be in gaseous (HT) or tritiated water vapor (HTO) form. The organically bound form of tritium is not present in any significant quantity in a source term, but may chemically transition to that form within vegetation following a release as tritium is incorporated into the food chain.

\section{Environmental Modeling of Tritium Releases}

Because of the large amounts of tritium at SRS and the mobility of tritium through the food chain, a tritium-specific model is used. The computer model UFOTRI is used for assessment of tritium releases [Raskob 1990, 1993]. UFOTRI was developed at the German Karlsruhe Laboratory to assess the radiological consequences of accidental atmospheric tritium releases. UFOTRI examines tritium specific processes such as the conversion of tritium gas (HT) into tritiated water (HTO), re-emission after deposition, and conversion of HTO into organically bound tritium (OBT) [O'Kula et al. 1998]. UFOTRI calculates inhalation/skin absorption doses from plume passage and couples the short-term atmospheric dispersion model with a first order compartment module that dynamically describes the long-term behavior of tritium in the food chains. Concentrations of tritium in foodstuffs after plume passage can be compared to FDA DILs. The higher degree of pathway model complexity available in computer models such as UFOTRI is needed to assess the effects of an acute release of tritium to the environment. The underlying dispersion model is Gaussian, consistent with regulatory recommendations.

Four food groups modeled in UFOTRI are of interest for ingestion dose assessment. These are vegetables, wheat grain, meat, and milk. Tritium concentrations in these food groups are calculated as a function of time. The concentration in a foodstuff may be the result of uptake from multiple pathways. For example, the concentration of tritium in vegetables may be the result of absorption of tritium from the atmosphere (during plume passage) and uptake of tritium from the soil through the plant's root system. Re-emission from the plant and conversion of HTO into OBT are modeled. 


\section{Input Parameters}

In the discussion which follows, a brief summary covering various input parameters is given, then more detail, along with examples, is presented.

As with particulates, adverse $\left(95^{\text {th }}\right.$ percentile) and average meteorology should be run. Adverse meteorology provides an indication of maximum impacts, while average meteorology provides a more typical perspective.

The basic meteorological parameters are summarized in Table 5 .

Table 5. Meteorological Input Parameters for Tritium Facilities for Average and Adverse Conditions

\begin{tabular}{|l|c|c|}
\hline Parameter & Average Met. & Adverse Met. \\
\hline Wind Speed Height & $10 \mathrm{~m}$ & $10 \mathrm{~m}$ \\
\hline Stability Class & $\mathrm{C}$ & $\mathrm{E}$ \\
\hline Wind Speed & $2.5 \mathrm{~m} / \mathrm{s}$ & $1.7 \mathrm{~m} / \mathrm{s}$ \\
\hline Inversion Layer & $500 \mathrm{~m}$ & $200 \mathrm{~m}$ \\
\hline Temperature & $25^{\circ} \mathrm{C}$ & $29^{\circ} \mathrm{C}$ \\
\hline
\end{tabular}

From WSRC-TR-99-00118 (Marx 1999b)

The release height is scenario dependent.

The chemical form of tritium when released can be HT, HTO, or a mixture of the two, depending on the particular accident scenario. As noted earlier, OBT may be present after tritium is absorbed and incorporated into organic matter.

Additional input parameters are summarized in Table 6.

Table 6. Additional Input Parameters for UFOTRI

\begin{tabular}{|c|c|c|c|}
\hline \multicolumn{2}{|c|}{$\begin{array}{l}\text { Source Term Information } \\
\text { Chemical Forms* } \\
(0-100) \% \text { HT / }(0-100) 100 \% \text { HTO } \\
\text { No building wake effect model assumed for IPZ modeling } \\
\text { Thermal energy of release } \quad 0 \mathrm{cal} / \mathrm{sec} \\
\end{array}$} & \multicolumn{2}{|c|}{$\begin{array}{ll}\text { Meteorology } & \\
\text { No Rainfall } & 0 \mathrm{~mm} / \mathrm{h} \\
\text { Wind direction (in degrees) } & \text { Arbitrary } \\
\text { Dispersion parameters } & \text { Briggs } \\
\text { Relative humidity } & 0.8 \\
\end{array}$} \\
\hline $\begin{array}{l}\text { Soil and vegetation } \\
\text { Soil type } \\
\text { Initial soil water content } \\
\text { Pore volume (default) }\end{array}$ & $\begin{array}{l}\text { Sandy loam } \\
35 \% \\
50 \%\end{array}$ & $\begin{array}{l}\text { Code coefficients } \\
\text { HTO dry deposition velocity** } \\
\text { HT dry deposition velocity*** }\end{array}$ & $\begin{array}{l}0.5 \mathrm{~cm} / \mathrm{s} \\
0.05 \mathrm{~cm} / \mathrm{s}\end{array}$ \\
\hline
\end{tabular}

O'Kula et al. (1998) provides a detailed explanation of the UFOTRI model along with SRSspecific parameters. Because that document is concerned with the plume exposure pathway, the ingestion pathway is not analyzed. A description of input data and assumptions for ingestion pathway analysis follows. 
The UFOTRI model uses one input file for site geometry, source term, meteorological conditions, environmental characteristics, radiological parameters, and output formats. In the following, a short description of a block of input is provided, followed by example input (boldface and indented). Examples are taken from Marx (1999b, WSRC-TR-99-00118), with several modifications.

\section{Site geometry and gridding}

1. UFOTRI allows a maximum of 20 radial distances and 72 angular segments. For the ingestion pathway application, an appropriate number of radial bands are used with the maximum number of sectors. In the example, 13 radial rings and 72 angular segments $\left(5^{\circ}\right.$ of arc each) are used. The large number of geometry elements results in each geometry element being approximately square. This is important for the area source model for reemission of tritium after plume passage. The user must specify the radial distance endpoints (RA array) and representative internal points (R array). For ingestion pathway calculations, a receptor should be located at the site boundary $(11,540$ meters for the H-Area example). Additional receptors should be located to help define the range and shape of the impacted area. In the example, receptors are located at $150 \mathrm{~m}, 500 \mathrm{~m}, 1,000 \mathrm{~m}, 3,500 \mathrm{~m}, 5,000 \mathrm{~m}$, $7,500 \mathrm{~m}, 10,000 \mathrm{~m}, 10,800 \mathrm{~m}, 11,540 \mathrm{~m}, 30,000 \mathrm{~m}, 50,000 \mathrm{~m}, 75,000 \mathrm{~m}$, and 100,000 m.

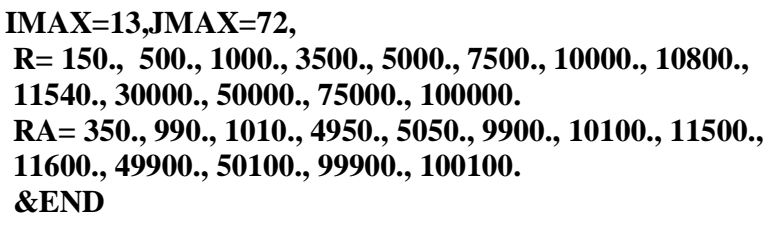

2. The population in each geometry element must be specified although population doses are not desired in this calculation. The identification number of the site according to the population data file is " 00 ", and is named "HOMOGEN". The population distribution is defined by distance bands out to and including band "IEIN", and uniform outside (NSTOPT=2). The probability of the HOMOGEN site is 1.0 since it is the only site. The uniform population density outside of band "IEIN" is 56.9 persons $/ \mathrm{km}^{2}$. IEIN is set equal to the $8^{\text {th }}$ band. The population is input for each angular segment, one ("North") through seventy-two in clockwise iterations, providing close-in data first, followed by increasingly more distant radial distances. For foodstuff concentration applications, the population numbers are placeholder values, since the code requires this information to execute.

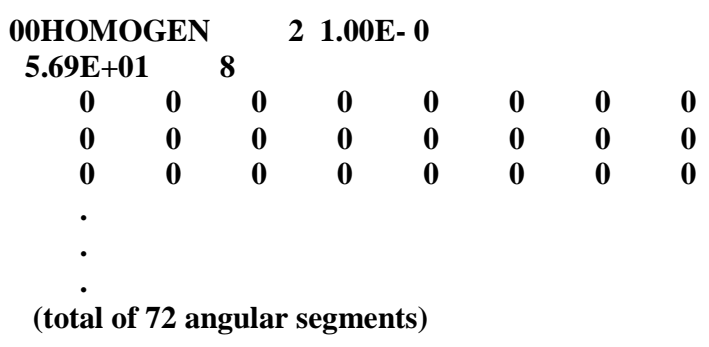

\section{Source term}

3. Two tritium chemical species can be modeled in UFOTRI, tritium gas (HT, DT, and $\mathrm{T}_{2}$ ) and tritiated water vapor (HTO, DTO, and $\mathrm{T}_{2} \mathrm{O}$ ). These are specified with default deposition velocities (VA array), whether a simple deposition or a more detailed biophysics model is invoked by the user. The more detailed biophysics model is used for ingestion pathway calculations, so the values in the VA array are placeholders. The order used in the UFOTRI code is tritium gas (1) and tritiated water vapor (2). 


\section{ISOTOPE \\ \&ISOPAR \\ NABL $=2$, \\ $\mathrm{VA}=5 . \mathrm{E}-4,0.005$}

4. The source term for the ingestion pathway example is "BDBAVG", there is one release phase, and a one-hour shift of the beginning of the weather sequences to the chosen start times (this has no effect with constant meteorology). The time between the end of the nuclear process and the start of each release phase is zero [IPHASE(1)=0]. The release height is from a 60 meter stack $[\operatorname{IHO}(1)=60]$ for this example (other scenarios may have a ground level release). There is no sensible heat in the release $[\mathrm{QH}(1)=0.0]$. No building wake effects are considered in this analysis, therefore the building width and height are each set to 1 meter $[(\mathrm{BR}(1)=\mathrm{HOE}(1)=1.000 \mathrm{E} 0]$.

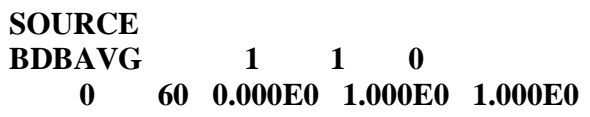

5. The source term is specified in one release phase, $100 \% \mathrm{HTO}[\mathrm{Q}(2,1)=1.0]$, and $0 \% \mathrm{HT}[\mathrm{Q}(1,1)=0.0]$. The total activity released is $3.7 \times 10^{15} \mathrm{~Bq}\left(10^{5} \mathrm{Ci}\right)$ in the example cited here.

$$
Q(2,1)=1.0, Q(1,1)=0.0, Q 1=3.7 E 15
$$

\section{Meteorological conditions}

6. Precalculated washout coefficients and precipitation rates (IWASH=0) would be used if rainfall occurs. (Precipitation is turned off by setting the rainfall rate to zero in Step 8 below).

\section{IWASH=0}

7. The meteorological "zone" is "SRSHTOST". Since constant meteorology has been specified, there is only one sequence sampled ( $\mathrm{LMAX}=1)$. There is only one meteorological site considered (NSTMAX $=1$ ). A uniform probability distribution (LPOPT $=0$ ) is specified since meteorology is constant. A file is used to specify the start time of each sequence (LWOPT=1), although in this example with constant meteorology the start time of 4332 hours is a placeholder. The index of surface roughness for the choice of dispersion parameters is for "mean roughness length", $10 \mathrm{~cm}<\mathrm{z} \leq 1 \mathrm{~m}$, applicable to rural areas with low plants (IRAU=2). IPZ sensitivity studies may also run cases with IRAU $=3$, corresponding to the "great roughness length", $\mathrm{z}>1 \mathrm{~m}$. For SRS, this selection would be useful to characterize forested areas. The windspeed height for the input data is $10 \mathrm{~m}(\mathrm{IHOM}=10)$. The time between sequences (IBEWE $=0$ ) is irrelevant here since there is only one sequence.

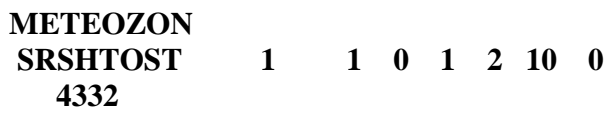

8. Constant meteorology is used $(\mathrm{METIN}=1)$. Parameters are generally consistent with guidance for performing Emergency Preparedness Hazards Assessments (TP-95-002 rev. 3) for the plume exposure pathway. In the example, a wind direction from the northwest (IWNDR=315), a windspeed of $2.5 \mathrm{~m} / \mathrm{s}$ $(\mathrm{IWNDG}=250)$, and no rainfall (IREGN=0) are specified. The variable IDIKAT sets the stability class $(A=1, B=2, C=3, D=4, E=5, F=6)$, which is " $C$ " for average meteorological conditions at SRS.

\section{METEOROL

9. The parameter KLUGSI=2 specifies that the Briggs dispersion parameterization will be used, Associated parameters scale the Briggs duration time and surface roughness assumptions. A 10- 
minute sampling time $($ RELTA=10.) and 10-cm surface roughness $($ RELRA $=10)$ are the bases for the Briggs data. Corresponding values for the scenario used for the example are a 60-minute release duration $(\mathrm{RELTN}=60$.) and 100-cm surface roughness (RELRN=100.).

Other parameter sets are available.

\section{KLUGSI $=2$, IRELTS=1 RELTA=10., RELTN=60., RELTP=0.20, IRELRS $=1$, RELRA $=10 .$, RELRN $=100$.}

10. In the example, the default value of the windshift option is used (NOSHFT=2) indicating that for each release phase hourly changes in the wind direction may be considered. For the example, the value is irrelevant since meteorology is constant. The mixing layer height is input as a function of stability class, and is in order of A through F $(1600 \mathrm{~m}, 1200 \mathrm{~m}, 500 \mathrm{~m}, 400 \mathrm{~m}, 300 \mathrm{~m}$, and $150 \mathrm{~m})$. The wind profile exponents are SRS-specific (WPE=0.08,0.10,0.11,0.18,0.31,0.42).

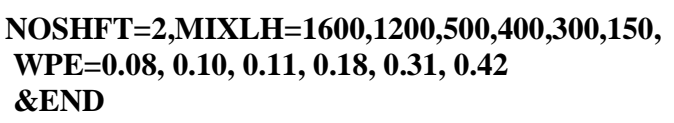

As indicated in the discussion on particulate dispersion, a mixing layer height of 300 meters is appropriate to use for SRS (Holzworth 1972) and should be used for future adverse meteorology (E stability) consequence calculations.

\section{Environmental characteristics}

11. The environmental model is based on the one-year meteorological dataset available (NJAHRE=1). The growing season is essentially the full year (day one $=1$ to day end $=365$ ). A second year under the same assumption is required input, although the code recognizes that the available basis file is one year in length.

\section{\&TRIDAT \\ NJAHRE $=1$, \\ LT1=1,LT2=365, LT3=366,LT4=730}

12. The minimum duration of the re-emission process is set at the default of 70 hours (NSTOP=70.). The reemission algorithm stops after two requirements have been met: re-emission has been occurring for at least NSTOP hours, and the amount of activity in the soil has been reduced to at least one-third of the tritium content after the tritium routine had started. The UFOTRI recommended value is used for BODFAK $(=100$.). This parameter determines the minimum source strength of a secondary area source of HTO from the soil and the vegetation, which will be considered in the reemission dispersion part of the analysis. The minimal source strength is calculated as equal to [maximal soil concentration] $\times$ BODFAK.

\section{NSTOP=70,BODFAK=1.E +2}

13. The reemission rate during rain events is set at the default value of 0.3 ( $\%$ per hour). The IZFREI parameter is the duration of the primary plume in seconds (IZFREI $=1800$ in this example). Next, IFLENG specifies the area source geometry for the reemission algorithm; the normal area source with fourteen points is specified (IFLENG $=0$ ). The IRFIX parameter indicates that UFOTRI will specify the reemission rate as the default recommendation (IRFIX=0). REFEST is the accompanying fixed reemission rate $(=5.0)$, but this is not used if IRFIX $=0$. ITEMPE (in units of $0.01^{\circ} \mathrm{C}$ ) is the environmental temperature $\left(30^{\circ} \mathrm{C}\right)$ if a persistent meteorological condition is specified. Similarly, ISTRBE is the fixed value for the radiation balance if a persistent meteorological condition is requested (METIN=1), and is set to the default value of 100 Watts. Water stress will occur in vegetation if the solar radiation has a value greater than ISTGR (dimension is Watts $/ \mathrm{m}^{2} \times 0.357 \times 0.8$ ). The default value of 200 joules $/ \mathrm{cm}^{2}$ corresponds to water stress at $700 \mathrm{Watts} / \mathrm{m}^{2}$. 


\section{REMRE $=0.3$, IZFREI $=1800$, IFLENG $=0$, IRFIX $=0$, REFEST $=5.0$, ITEMPE $=3000$, ISTRBE $=100$, ISTRGR $=200$}

14. The roughness length is set at $10 \mathrm{~cm}(\mathrm{ARAU}=0.1)$, and the assumed water fraction in the soil is $35 \%$ (based on SRS conditions). A roughness length of $10 \mathrm{~cm}$ corresponds to open country with few trees or bushes; a roughness length of $100 \mathrm{~cm}$ corresponds to dense forests and small towns. In contrast to plume exposure calculations that use a roughness length of $100 \mathrm{~cm}$, ingestion pathway calculations use a roughness length of $10 \mathrm{~cm}$, since $10 \mathrm{~cm}$ more closely matches areas where food and feed are grown.

\section{ARAU $=0.1, B O D E I N=0.35$}

15. Hard-wired models for food ingestion are present in UFOTRI. For example, NCOW, WWCOW, and WOCOW are the number of cows grazing per square kilometer, the mass content of the inorganic part ( $\mathrm{kg}$ per cow) and mass content of the organic fraction of a cow ( $\mathrm{kg}$ per cow). The default values are used in the example. The time checkpoints (in days) for removing food restrictions are the TIMEDO values. They are not used for calculation of radionuclide concentrations in food.

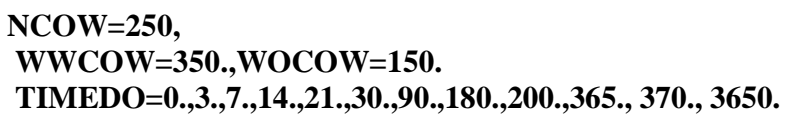

16. UFOTRI employs an areal density for soil type and vegetation coverage. Thus, the SRS Site application must identify estimates that account for characteristics of the site on a regional basis, while minimizing unneeded UFOTRI models and food ingestion assumptions. Observing these limitations, the fraction of area assigned to various crops or vegetation must be specified. The sum of the fractions must equal one. The fraction of the area reserved for agricultural production and vegetation is assumed to be 0.5 (FAKC1 $=0.5$ ). In the example, fractional areas for grazing animals (FAKC2), potatoes (FAKCP), and wheat (FAKCW) are set at $0.35,0.05$, and 0.1 , respectively.

\section{FAKC1 $=0.5, F A K C 2=0.35, F A K C P=0.05, F A K C W=0.1$}

17. The vegetation characteristics for vegetables in terms of input to UFOTRI must be estimated. The minimum stomata diffusion resistance ( $\mathrm{RCMIN}=2$.) of the canopy for the type 1 vegetation (taken as vegetables in this example) is based on the UFOTRI User's Manual.

18. A second quantity needed is the leaf area index. This parameter provides the vegetation coverage area $\left(\mathrm{m}^{2}\right)$ per unit area of land. The value LEAF $=3.0$ is based on the UFOTRI User's Manual.

19. The final two inputs are the mass of vegetation water in vegetation type $\mathbf{1}$ and the mass content of the organic parts of the plant. Both parameters are in units of $\mathrm{g} / \mathrm{m}^{2}$. The values $\mathrm{BEWG}=1440$. and $B E W G Z=160$ are default values from UFOTRI.

The sets of input for the other three vegetation types are default values from UFOTRI. Site-specific values should be used if available.

Table 7. Key Input Values for Four Vegetation Types in UFOTRI

\begin{tabular}{|l|c|c|c|c|}
\hline Vegetation Type & $\begin{array}{c}\text { RCMIN } \\
(\mathbf{s} / \mathbf{c m})\end{array}$ & $\begin{array}{c}\text { Leaf area } \\
\text { index, } \mathbf{L}_{\mathbf{A}} \\
\left(\mathbf{m}^{\mathbf{2}} / \mathbf{m}^{\mathbf{2}}\right)\end{array}$ & $\begin{array}{c}\text { Vegetation Mass in } \\
\text { Water per unit } \\
\text { ground area } \\
\left(\mathbf{g} / \mathbf{m}^{\mathbf{2}}\right)\end{array}$ & $\begin{array}{c}\text { Organic } \\
\text { Vegetation Mass } \\
\text { per unit ground } \\
\text { area }\left(\mathbf{g} / \mathbf{m}^{2}\right)\end{array}$ \\
\hline 1. Vegetables & 2. & 3. & 1440. & 160. \\
\hline 2. Grass & 2. & 3. & 680. & 170. \\
\hline 3. Potatoes & 2. & 4.7 & 2700 & 300. \\
\hline 4. Wheat & 2. & 7. & 2000 & 500. \\
\hline
\end{tabular}




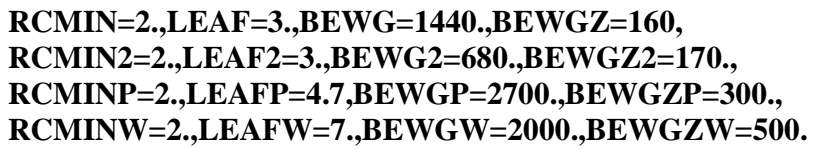

20. A list of consumption rates for various foodstuffs is next in the environmental input. These are potato, wheat, milk, vegetables, and meat consumption rates in grams per day.

IPOT=233,IWHEAT=261,IMILK=315,IVEGE=124,IMEAT $=206$

21. A final set of information must be specified to control the biophysics models used in the calculation. The plant resistance model is the extended model that considers radiation balance, air temperature, air humidity water content of soil, water stress from high solar radiation (IMODEL $=1$ ). The soil option used that best characterizes the area around SRS is loamy sand (IARTBO=2) (O'Kula 1998 and WSRC 1993). The default wilting point value is used, at which stomata closure occurs (WILTP=0.1). The default value for fraction of the maximum free pore volume of soil is used (SOILMX $=0.5$ ). Next, the extended model (IBODEX=1) is used for the transport of water in soil. The extended model accounts for suction tension and soil conductivity.

\section{IMODEL $=1$, IARTBO=2,WILTP=0.1,SOILMX $=0.5$, IBODEX $=1$}

22. The Monteith resistance approach is applied $(\mathrm{IMONT}=1)$ for calculating the evaporation-transpiration. It is assumed that irrigation of agricultural and grassy areas is not performed (IRRIGA $=I R R I G G=0$ ). The full resistance model for HTO deposition to soil is invoked (IFLAGS=1) in conjunction with the soil resistance model (IFLAGR=1). Similarly, the resistance model is used for HT deposition to soil $(\mathrm{IDEPHT}=1)$ rather than the predefined deposition velocity.

\section{IMONT=1,IRRIGA=0,IRRIGG=0,IFLAGS=1,IFLAGR=1,IDEPHT=1}

23. The initial water content is assumed to be the BODEIN value (35\%), equal in all three layers $($ IBODFX $=0$ ). The ICOVER parameter indicates the choice of model for calculating the actual plant stage, and setting ICOVER equal to 1 specifies replacing the initial values by the calculated ones. The day of release is set to the default of Day 181 (IRELIN=181). IPHOTO=1 calculates the photosynthesis rate which is associated with the hourly HTO transfer rates into OBT. Finally, IARIV $=0$ indicates that the plume arrival and footprint as a function of travel time is not requested.

\section{IBODFX=0,ICOVER=1,IRELIN=181,IPHOTO=1,IARIV=0} \&END

\section{Radiological specifications}

24. As recommended by the International Commission on Radiological Protection (ICRP) in Publication 30, the fifty-year committed effective dose equivalent conversion factor for tritium oxide is used [ICRP, 1978]. Others shown are 1.7E-15 Sv/Bq for HT and 4.0E-11 $\mathrm{Sv} / \mathrm{Bq}$ for OBT [Raskob, 1990]. The assumed breathing rate is $3.33 \times 10^{-4}$ cubic meters per second which is the DOE occupational breathing rate [DOE, 1989]; the skin absorption rate is one-half that through breathing (1.665E-04). These dose-related factors are not used when comparing concentrations in foods to FDA DILs.

DOSF $=1.7 E-11$,

DOSHT=1.7E-15,DOSFOB=4.0E-11,BRRATE=3.33E-4,SKRATE=1.665E-04

\section{Output specification}

25. A detailed printout of the concentration for each tritium species at the various grid radii is requested $(\mathrm{NOOTKZ}=1)$. No detailed printout is requested for meteorological and trajectory data 
(NOOTMT $=0$ ). A printout for all thirteen distance bands is specified (IACT=13*1). Most options for detailed concentration printout by region are turned off (IZUSD, IZUAUS, and KAUSDR). KAUSDR(2)=1 provides a printout of concentrations in foodstuffs. Output listings for concentrations in foodstuffs are limited to one location. The location is specified by sector (IFACHS) and radius (IEINR2). In the example, concentrations in Sector 28 (IFACHS=28) at a distance of the first radius (IEINR2 $=1$ ) are requested (directly downwind for the specified wind direction of $315^{\circ}$. Concentrations as a function of time are obtained.

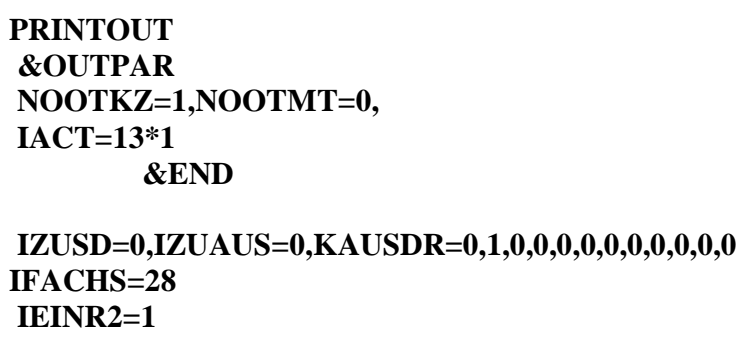

A sample input file is provided in Appendix $\mathrm{R}$.

Several full input files are included in Marx (1999a and 1999b). While research into SRSspecific parameters for use in tritium dispersion models has been performed, UFOTRI codespecific parameters may still need to be refined depending on the nature of the IPZ calculation.

\section{Comparison with FDA DILs}

To evaluate the release, calculated concentrations in vegetables, wheat grain, meat, and milk for multiple distances and times following the release are compared with the HTO and OBT DILs. DILs for HTO and OBT were presented in Table 2. Tritium concentrations in grass, although calculated in UFOTRI, are not examined since grass is not directly consumed by humans. However, tritium concentrations in grass are indirectly incorporated via the meat and milk pathways. In all instances, the HTO and OBT concentrations are summed prior to comparison with the appropriate DIL.

For short-term concentrations, the time at which the peak HTO concentration occurs in each food type should be found. The summed HTO and OBT concentrations are compared with the HTO DIL. In the time immediately following the release, the HTO concentration quickly reaches its peak and is the dominant form of tritium present in foodstuffs.

For long-term concentrations, two evaluation times, one week (168 hours) and one year (8760 hours), are used. The OBT DIL is used for these comparisons because the tritium will be incorporated into organic compounds that have a greater biological half-life than HTO. For plants, the HTO half-life is approximately one hour while the OBT half-life ranges from 8 hours to over 10 days. Examinations of long-term concentrations are useful to determine if interdiction is still required.

Concentrations for both the short and long-term should be examined at the facility boundary, 1 $\mathrm{km}, 10 \mathrm{~km}$, site boundary, $50 \mathrm{~km}$, and $100 \mathrm{~km}$ from the release. The facility and site boundary concentrations may be used to determine if any intervention will be necessary. The concentration at $100 \mathrm{~km}$ is used for comparison with the particulate concentrations. (The code 
used to calculate concentrations for particulates, HOTSPOT, calculates up to a maximum distance of $100 \mathrm{~km}$.) The remaining distances are chosen to examine intermediate distances.

\section{CONCLUSION}

A recommended methodology has been described to evaluate the ingestion pathway consequences of accidental airborne radiological releases from facilities at the Savannah River Site. Due to the variation in behavior of particulate and tritium species in the environment, the approaches differ. Specific values of coefficients and transfer factors for many radionuclides potentially released as part of SRS source terms are presented in appendices. For radionuclides not explicitly addressed here, a recommended default procedure is outlined. 


\section{REFERENCES}

Department of Energy. Emergency Management Guide-Hazards Surveys and Assessments. Washington, DC: DOE; DOE G 151.1-1 Vol. 2, 1997.

Department of Energy. Implementation Guide for use with DOE Order 440.1 Occupational Exposure Assessment, U.S. Department of Energy, Washington, DC, DOE G 440.1-3, 1998.

Environmental Protection Agency. Manual of Protective Action Guides and Protective Actions for Nuclear Incidents. Washington, DC: EPA; EPA 400-R-92-001, 1992.

Food and Drug Administration. Accidental radioactive contamination of human food and animal feeds: recommendations for state and local agencies. Federal Register Vol. 47, No. 205, pages 47073-47083: FDA; October 22, 1982.

Food and Drug Administration. Accidental Radioactive Contamination of Human Foods and Animal Feeds: Recommendations for State and Local Agencies. Rockville, MD: FDA; August 13, 1998.

Hadlock, D. J. Consequence Assessment for Emergency Preparedness Hazards Assessments, Aiken, SC; Westinghouse Savannah River Company; TP-95-002 Rev. 3, 1997

Hamby, D. M. Land and Water Use Characteristics in the Vicinity of the Savannah River Site. Aiken, SC; Westinghouse Savannah River Company; WSRC-RP-91-17; March 1991.

Hamby, D. M. Site-Specific Parameter Values for the Nuclear Regulatory Commission's Food Pathway Dose Model. Health Phys. 62(2):136-143; 1992.

Holzworth, G. C. Mixing Heights, Windspeeds, and Potential for Urban Air Pollution Throughout the Contiguous United States, U. S. EPA, Division of Meteorology, Research Triangle Park, NC, January 1972.

Homann, Steven G. HOTSPOT Health Physics Codes for the PC, UCRL-MA-106315, Lawrence Livermore National Laboratory, University of California, Livermore, CA, March 1994.

International Atomic Energy Agency. Handbook of Parameter Values for the Prediction of Radionuclide Transfer in Temperate Environments. Vienna: IAEA; Technical Reports Series No. 364; 1994.

International Commission on Radiation Protection. Radiation Protection: ICRP Publication 30 Part 1 Limits for Intakes of Radionuclides by Workers, Pergamon Press, New York, NY.

Marx, D. R. Foodstuff Concentrations Following a SRTC Tritium Oxide Release (U), Aiken, SC; Westinghouse Savannah River Company; WSRC-TR-99-00117, Rev. 0; April 1999a. 
Marx, D. R. Foodstuff Concentrations and Relocation Considerations Following a Tritium Oxide Release from SRS Tritium Facilities (U), Aiken, SC; Westinghouse Savannah River Company; WSRC-TR-99-00118, Rev. 0; April 1999b.

National Council on Radiation Protection and Measurements. Environmental Radiation Measurements. Bethesda, MD: NCRP; NCRP Report No.50; 1976.

National Council on Radiation Protection and Measurements. Screening Models for Releases of Radionuclides to Atmosphere, Surface Water, and Ground. Bethesda, MD: NCRP; NCRP Report No.123; 1996.

Nuclear Regulatory Commission. Calculation of Annual Doses to Man from Routine Releases of Reactor Effluents for the Purpose of Evaluating Compliance with 10 CFR Part 50, Appendix I. Washington, DC: NRC; Regulatory Guide 1.109, Rev. 1; 1977.

O'Kula, K. R. Dose/Unit Activity Released for Tritium Facilities Consequence Analysis, Aiken, SC; Westinghouse Savannah River Company; S-CLC-H-00631, Rev. 0; April 1998.

O’Kula, K. R.; East, J. M.; Murphy, Jr., C. E. Evaluating Postulated Tritium Releases on a Large DOE Site Using the UFOTRI Probabilistic Consequence Model (U). In: Proceedings of the $4^{\text {th }}$ International Conference on Probabilistic Safety Assessment and Management; 1998.

Randerson, Darryl (ed.). Atmospheric Science and Power Production, U.S. Department of Energy, Washington, D.C., DOE/TIC-27601 (DE84005177), July 1984.

Raskob, W. UFOTRI: Program for Assessing the Off-Site Consequences From Accidental Tritium Releases, Kernforschungszentrum Karlsruhe GmbH, Karlsruhe, KfK 4605, July 1990.

Raskob, W. Description of the New Version 4.0 of the Tritium Model UFOTRI Including User Guide, Kernforschungszentrum Karlsruhe GmbH, Karlsruhe, KfK 5194, August 1993.

Shleien, B.; Chiacchierini, R. Background for Protective Action Recommendations: Accidental Radioactive Contamination of Food And Animal Feeds. Rockville, MD: FDA; HHS Publication FDA 82-8196; 1982.

Tharakan B. K. Derived Intervention levels for Tritium Based on Food and Drug Administration Methodology Using ICRP 56 Dose Coefficients $(U)$. Westinghouse Savannah River Company, Aiken, SC, WSRC-TR-99-00064.

Thompson, J. M. Ingestion Pathway Consequences of an H-Separations Coil and Tube Failure $(U)$, Aiken, SC; Westinghouse Savannah River Company; WSRC-TR-99-00089, Rev. 0; April 1999a.

Thompson, J. M. Ingestion Pathway Transfer Factors for Particulates, Aiken, SC; Westinghouse Savannah River Company; S-CLC-G-00179, Rev. A; March 1999c. 
Thompson, J. M. Selection of Models for Ingestion Pathway and Relocation (U), Aiken, SC; Westinghouse Savannah River Company; WSRC-TR-98-00392, Rev. 2; February, 1999 b.

Till, J.; Meyer, H. Radiological Assessment. Washington, DC: NRC; NUREG/CR-3332/ ORNL-5968; 1983.

Westinghouse Savannah River Company. Standards for Development and Maintenance of an Emergency Preparedness Hazards Assessment, Aiken, SC; Westinghouse Savannah River Company; WSRC Manual 6Q Volume II, EMPP 6Q-001 Rev. 2, May 21, 1999.

Westinghouse Savannah River Company. SRS Ecology, Environmental Information Document, Westinghouse Savannah River Company, Savannah River Site, Aiken, SC, WSRC-TR-93-496, September 1993. 


\section{APPENDIX A. PRODUCE TRANSFER FACTORS (DIRECT DEPOSITION)}

Table A-1 lists the transfer coefficients for external contamination of produce from direct deposition.

Table A-1. External Contamination of Produce from Direct Deposition

\begin{tabular}{lccc}
\hline Nuclide & $\mathrm{r}$ & $\mathrm{Y}_{\mathrm{v}}$ & $\mathrm{T}\left(\mathrm{m}^{2} / \mathrm{kg}\right)$ \\
\hline Am-241 & 0.2 & 0.7 & 0.29 \\
Am-243 & 0.2 & 0.7 & 0.29 \\
Ba-133 & 0.2 & 0.7 & 0.29 \\
Ce-144 & 0.2 & 0.7 & 0.29 \\
Cf-249 & 0.2 & 0.7 & 0.29 \\
Cf-252 & 0.2 & 0.7 & 0.29 \\
Cm-244 & 0.2 & 0.7 & 0.29 \\
Cm-246 & 0.2 & 0.7 & 0.29 \\
Co-60 & 0.2 & 0.7 & 0.29 \\
Cs-137 & 0.2 & 0.7 & 0.29 \\
Np-237 & 0.2 & 0.7 & 0.29 \\
Pm-147 & 0.2 & 0.7 & 0.29 \\
Pu-238 & 0.2 & 0.7 & 0.29 \\
Pu-239 & 0.2 & 0.7 & 0.29 \\
Pu-240 & 0.2 & 0.7 & 0.29 \\
Pu-241 & 0.2 & 0.7 & 0.29 \\
Pu-242 & 0.2 & 0.7 & 0.29 \\
Sr-90 & 0.2 & 0.7 & 0.29 \\
Tc-99 & 0.2 & 0.7 & 0.29 \\
Th-232 & 0.2 & 0.7 & 0.29 \\
Tl-204 & 0.2 & 0.7 & 0.29 \\
U-235 & 0.2 & 0.7 & 0.29 \\
U-238 & 0.2 & 0.7 & 0.29 \\
Referce: & &
\end{tabular}

Reference: Thompson 1999c: Ingestion Pathway Transfer Factors for Particulates.

"r" values are from RG 1.109, page 68.

"Y $\mathrm{v}_{\mathrm{v}}$ values are from Hamby 1991. 


\section{APPENDIX B. PRODUCE TRANSFER FACTORS (ROOT UPTAKE)}

Table B-1 lists the transfer factors for internal contamination of produce from root uptake.

\section{Table B-1. Internal Contamination of Produce from Root Uptake}

\begin{tabular}{lccc}
\hline Nuclide & ${ }_{\mathrm{i}} \mathrm{CR}$ soil to produce, dry & ${ }_{\mathrm{i}} \mathrm{CR}_{\text {soil to produce, dry }} / 7=\mathrm{B}_{\text {wet }}$ & $\mathrm{T}=\mathrm{B}_{\text {wet }} / 280 \mathrm{~m}^{2} / \mathrm{kg}$ \\
\hline $\mathrm{Am}-241$ & $6.60 \mathrm{E}-04$ & $9.43 \mathrm{E}-05$ & $3.37 \mathrm{E}-07$ \\
$\mathrm{Am}-243$ & $6.60 \mathrm{E}-04$ & $9.43 \mathrm{E}-05$ & $3.37 \mathrm{E}-07$ \\
$\mathrm{Ba}-133$ & $3.00 \mathrm{E}-02$ & $4.29 \mathrm{E}-03$ & $1.53 \mathrm{E}-05$ \\
$\mathrm{Ce}-144$ & $3.00 \mathrm{E}-02$ & $4.29 \mathrm{E}-03$ & $1.53 \mathrm{E}-05$ \\
$\mathrm{Cf}-249$ & $*$ & $*$ & $*$ \\
$\mathrm{Cf}-252$ & $*$ & $*$ & $*$ \\
$\mathrm{Cm}-244$ & $7.70 \mathrm{E}-04$ & $1.10 \mathrm{E}-04$ & $3.93 \mathrm{E}-07$ \\
$\mathrm{Cm}-246$ & $7.70 \mathrm{E}-04$ & $1.10 \mathrm{E}-04$ & $3.93 \mathrm{E}-07$ \\
$\mathrm{Co}-60$ & $2.00 \mathrm{E}-01$ & $2.86 \mathrm{E}-02$ & $1.02 \mathrm{E}-04$ \\
$\mathrm{Cs}-137$ & $4.60 \mathrm{E}-01$ & $6.57 \mathrm{E}-02$ & $2.35 \mathrm{E}-04$ \\
$\mathrm{~Np}-237$ & $3.70 \mathrm{E}-02$ & $5.29 \mathrm{E}-03$ & $1.89 \mathrm{E}-05$ \\
$\mathrm{Pm}-147$ & $*$ & $*$ & $*$ \\
Pu-238 & $7.30 \mathrm{E}-05$ & $1.04 \mathrm{E}-05$ & $3.72 \mathrm{E}-08$ \\
Pu-239 & $7.30 \mathrm{E}-05$ & $1.04 \mathrm{E}-05$ & $3.72 \mathrm{E}-08$ \\
Pu-240 & $7.30 \mathrm{E}-05$ & $1.04 \mathrm{E}-05$ & $3.72 \mathrm{E}-08$ \\
Pu-241 & $7.30 \mathrm{E}-05$ & $1.04 \mathrm{E}-05$ & $3.72 \mathrm{E}-08$ \\
Pu-242 & $7.30 \mathrm{E}-05$ & $1.04 \mathrm{E}-05$ & $3.72 \mathrm{E}-08$ \\
Sr-90 & $3.00 \mathrm{E}+00$ & $4.29 \mathrm{E}-01$ & $1.53 \mathrm{E}-03$ \\
Tc-99 & $2.00 \mathrm{E}+02$ & $2.86 \mathrm{E}+01$ & $1.02 \mathrm{E}-01$ \\
Th-232 & $1.80 \mathrm{E}-03$ & $2.57 \mathrm{E}-04$ & $9.18 \mathrm{E}-07$ \\
Tl-204 & $*$ & $*$ & $*$ \\
$\mathrm{U}-235$ & $8.30 \mathrm{E}-03$ & $1.19 \mathrm{E}-03$ & $4.23 \mathrm{E}-06$ \\
$\mathrm{U}-238$ & $8.30 \mathrm{E}-03$ & $1.19 \mathrm{E}-03$ & $4.23 \mathrm{E}-06$ \\
\hline
\end{tabular}

* factors not available

Reference: Thompson 1999c: Ingestion Pathway Transfer Factors for Particulates.

Dry concentration ratios are from IAEA 364, Table VI. Conversion to wet weight (factor of 7) per IAEA 364, section 2.4, page 26. When concentration ratios for different soil types were listed, the most limiting concentration ratio was selected. The soil depth $(20 \mathrm{~cm})$ and density $\left(1.4 \mathrm{~g} \mathrm{~cm}^{-3}\right)$ are combined to give an areal density of $280 \mathrm{~kg} \mathrm{~m}^{-2}$, consistent with IAEA 364 . 


\section{APPENDIX C. LEAFY VEGETABLE TRANSFER FACTORS (EXTERNAL CONTAMINATION DURING HARVEST)}

Table C-1 lists the transfer factors for external contamination of leafy vegetables during harvest.

\section{Table C-1. External Contamination of Leafy Vegetables During Harvest}

\begin{tabular}{lccc}
\hline Nuclide & dry kg/wet kg & soil/dry produce & $\mathrm{T}\left(\mathrm{m}^{2} / \mathrm{kg}\right)$ \\
\hline $\mathrm{Am}-241$ & 0.14 & 0.01 & $5.10 \mathrm{E}-06$ \\
$\mathrm{Am}-243$ & 0.14 & 0.01 & $5.10 \mathrm{E}-06$ \\
$\mathrm{Ba}-133$ & 0.14 & 0.01 & $5.10 \mathrm{E}-06$ \\
$\mathrm{Ce}-144$ & 0.14 & 0.01 & $5.10 \mathrm{E}-06$ \\
$\mathrm{Cf}-249$ & 0.14 & 0.01 & $5.10 \mathrm{E}-06$ \\
$\mathrm{Cf}-252$ & 0.14 & 0.01 & $5.10 \mathrm{E}-06$ \\
$\mathrm{Cm}-244$ & 0.14 & 0.01 & $5.10 \mathrm{E}-06$ \\
$\mathrm{Cm}-246$ & 0.14 & 0.01 & $5.10 \mathrm{E}-06$ \\
$\mathrm{Co}-60$ & 0.14 & 0.01 & $5.10 \mathrm{E}-06$ \\
$\mathrm{Cs}-137$ & 0.14 & 0.01 & $5.10 \mathrm{E}-06$ \\
$\mathrm{~Np}-237$ & 0.14 & 0.01 & $5.10 \mathrm{E}-06$ \\
$\mathrm{Pm}-147$ & 0.14 & 0.01 & $5.10 \mathrm{E}-06$ \\
$\mathrm{Pu}-238$ & 0.14 & 0.01 & $5.10 \mathrm{E}-06$ \\
$\mathrm{Pu}-239$ & 0.14 & 0.01 & $5.10 \mathrm{E}-06$ \\
$\mathrm{Pu}-240$ & 0.14 & 0.01 & $5.10 \mathrm{E}-06$ \\
$\mathrm{Pu}-241$ & 0.14 & 0.01 & $5.10 \mathrm{E}-06$ \\
$\mathrm{Pu}-242$ & 0.14 & 0.01 & $5.10 \mathrm{E}-06$ \\
$\mathrm{Sr}-90$ & 0.14 & 0.01 & $5.10 \mathrm{E}-06$ \\
Tc-99 & 0.14 & 0.01 & $5.10 \mathrm{E}-06$ \\
Th-232 & 0.14 & 0.01 & $5.10 \mathrm{E}-06$ \\
$\mathrm{Tl}-204$ & 0.14 & 0.01 & $5.10 \mathrm{E}-06$ \\
$\mathrm{U}-235$ & 0.14 & 0.01 & $5.10 \mathrm{E}-06$ \\
$\mathrm{U}-238$ & 0.14 & 0.01 & $5.10 \mathrm{E}-06$ \\
\hline Refrence & & &
\end{tabular}

Reference: Thompson 1999c: Ingestion Pathway Transfer Factors for Particulates.

The ratio dry $\mathrm{kg} /$ wet $\mathrm{kg}$ is assumed equal to $1 / 7$, per IAEA 364 , section 2.4 , page 26 . The soil weight per kg dry weight of the plant is $10 \mathrm{~g}$ per kilogram, or 0.01 per Table VII of IAEA 364. The soil depth $(20 \mathrm{~cm})$ and density $\left(1.4 \mathrm{~g} \mathrm{~cm}^{-3}\right)$ are combined to give an areal density of $280 \mathrm{~kg} \mathrm{~m}^{-2}$, consistent with IAEA 364. 


\section{APPENDIX D. GRAIN TRANSFER FACTORS (DIRECT DEPOSITION)}

Table D-1 lists the transfer factors for external contamination of grain from direct deposition.

Table D-1. External Contamination of Grain

\begin{tabular}{lccc}
\hline Nuclide & $\mathrm{r}$ & $\mathrm{Y}_{\mathrm{v}}$ & $\mathrm{T}\left(\mathrm{m}^{2} / \mathrm{kg}\right)$ \\
\hline Am-241 & 0.2 & 0.7 & 0.29 \\
Am-243 & 0.2 & 0.7 & 0.29 \\
Ba-133 & 0.2 & 0.7 & 0.29 \\
Ce-144 & 0.2 & 0.7 & 0.29 \\
Cf-249 & 0.2 & 0.7 & 0.29 \\
Cf-252 & 0.2 & 0.7 & 0.29 \\
Cm-244 & 0.2 & 0.7 & 0.29 \\
Cm-246 & 0.2 & 0.7 & 0.29 \\
Co-60 & 0.2 & 0.7 & 0.29 \\
Cs-137 & 0.2 & 0.7 & 0.29 \\
Np-237 & 0.2 & 0.7 & 0.29 \\
Pm-147 & 0.2 & 0.7 & 0.29 \\
Pu-238 & 0.2 & 0.7 & 0.29 \\
Pu-239 & 0.2 & 0.7 & 0.29 \\
Pu-240 & 0.2 & 0.7 & 0.29 \\
Pu-241 & 0.2 & 0.7 & 0.29 \\
Pu-242 & 0.2 & 0.7 & 0.29 \\
Sr-90 & 0.2 & 0.7 & 0.29 \\
Tc-99 & 0.2 & 0.7 & 0.29 \\
Th-232 & 0.2 & 0.7 & 0.29 \\
Tl-204 & 0.2 & 0.7 & 0.29 \\
U-235 & 0.2 & 0.7 & 0.29 \\
U-238 & 0.2 & 0.7 & 0.29 \\
\hline Refr
\end{tabular}

Reference: Thompson 1999c: Ingestion Pathway Transfer Factors for Particulates.

"r" values are from RG 1.109, page 68.

"Y $\mathrm{v}_{\mathrm{v}}$ values are from Hamby 1991. 


\section{APPENDIX E. GRAIN TRANSFER FACTORS (ROOT UPTAKE)}

Table E-1 lists the transfer factors for internal contamination of grain by root uptake.

Table E-1. Internal Contamination of Grain by Root Uptake

\begin{tabular}{lccc}
\hline Nuclide & ${ }_{\mathrm{i}} \mathrm{CR}_{\text {soil to grain, dry }}$ & $\mathrm{B}_{\text {wet }}={ }_{\mathrm{i}} \mathrm{CR}_{\text {soil to grain, dry }} \times 0.86$ & $\mathrm{~T}=\mathrm{B}_{\text {wet }} / 280 \mathrm{~m}^{2} / \mathrm{kg}$ \\
\hline Am-241 & $2.20 \mathrm{E}-05$ & $1.89 \mathrm{E}-05$ & $6.76 \mathrm{E}-08$ \\
Am-243 & $2.20 \mathrm{E}-05$ & $1.89 \mathrm{E}-05$ & $6.76 \mathrm{E}-08$ \\
Ba-133 & $3.00 \mathrm{E}-02$ & $2.58 \mathrm{E}-02$ & $9.21 \mathrm{E}-05$ \\
Ce-144 & $3.00 \mathrm{E}-02$ & $2.58 \mathrm{E}-02$ & $9.21 \mathrm{E}-05$ \\
Cf-249 & $*$ & $*$ & $*$ \\
Cf-252 & $*$ & $*$ & $*$ \\
Cm-244 & $2.10 \mathrm{E}-05$ & $1.81 \mathrm{E}-05$ & $6.45 \mathrm{E}-08$ \\
Cm-246 & $2.10 \mathrm{E}-05$ & $1.81 \mathrm{E}-05$ & $6.45 \mathrm{E}-08$ \\
Co-60 & $3.70 \mathrm{E}-03$ & $3.18 \mathrm{E}-03$ & $1.14 \mathrm{E}-05$ \\
Cs-137 & $8.30 \mathrm{E}-02$ & $7.14 \mathrm{E}-02$ & $2.55 \mathrm{E}-04$ \\
Np-237 & $2.70 \mathrm{E}-03$ & $2.32 \mathrm{E}-03$ & $8.29 \mathrm{E}-06$ \\
Pm-147 & $*$ & $*$ & $*$ \\
Pu-238 & $8.60 \mathrm{E}-06$ & $7.40 \mathrm{E}-06$ & $2.64 \mathrm{E}-08$ \\
Pu-239 & $8.60 \mathrm{E}-06$ & $7.40 \mathrm{E}-06$ & $2.64 \mathrm{E}-08$ \\
Pu-240 & $8.60 \mathrm{E}-06$ & $7.40 \mathrm{E}-06$ & $2.64 \mathrm{E}-08$ \\
Pu-241 & $8.60 \mathrm{E}-06$ & $7.40 \mathrm{E}-06$ & $2.64 \mathrm{E}-08$ \\
Pu-242 & $8.60 \mathrm{E}-06$ & $7.40 \mathrm{E}-06$ & $2.64 \mathrm{E}-08$ \\
Sr-90 & $2.10 \mathrm{E}-01$ & $1.81 \mathrm{E}-01$ & $6.45 \mathrm{E}-04$ \\
Tc-99 & $7.30 \mathrm{E}-01$ & $6.28 \mathrm{E}-01$ & $2.24 \mathrm{E}-03$ \\
Th-232 & $3.40 \mathrm{E}-05$ & $2.92 \mathrm{E}-05$ & $1.04 \mathrm{E}-07$ \\
Tl-204 & $*$ & $*$ & $*$ \\
U-235 & $1.30 \mathrm{E}-03$ & $1.12 \mathrm{E}-03$ & $3.99 \mathrm{E}-06$ \\
$\mathrm{U}-238$ & $1.30 \mathrm{E}-03$ & $1.12 \mathrm{E}-03$ & $3.99 \mathrm{E}-06$ \\
\hline
\end{tabular}

* factors not available

Reference: Thompson 1999c: Ingestion Pathway Transfer Factors for Particulates.

Dry concentration ratios are from IAEA 364, Table VI. Conversion to wet weight (factor of $0.86)$ per IAEA 364 , Table $\mathrm{V}$, page 15 . When concentration ratios for different soil types were listed, the most limiting concentration ratio was selected. The soil depth $(20 \mathrm{~cm})$ and density $\left(1.4 \mathrm{~g} \mathrm{~cm}^{-3}\right)$ are combined to give an areal density of $280 \mathrm{~kg} \mathrm{~m}^{-2}$, consistent with IAEA 364 . 


\section{APPENDIX F. GRAIN TRANSFER FACTORS (EXTERNAL CONTAMINATION DURING HARVEST)}

Table F-1 lists the transfer factors for external contamination of grain during harvest.

\section{Table F-1. External Contamination of Grain During Harvest}

\begin{tabular}{lccc}
\hline Nuclide & dry kg/wet kg & soil/dry grain & $\mathrm{T}\left(\mathrm{m}^{2} / \mathrm{kg}\right)$ \\
\hline $\mathrm{Am}-241$ & 0.86 & 0.004 & $1.23 \mathrm{E}-05$ \\
$\mathrm{Am}-243$ & 0.86 & 0.004 & $1.23 \mathrm{E}-05$ \\
$\mathrm{Ba}-133$ & 0.86 & 0.004 & $1.23 \mathrm{E}-05$ \\
$\mathrm{Ce}-144$ & 0.86 & 0.004 & $1.23 \mathrm{E}-05$ \\
$\mathrm{Cf}-249$ & 0.86 & 0.004 & $1.23 \mathrm{E}-05$ \\
$\mathrm{Cf}-252$ & 0.86 & 0.004 & $1.23 \mathrm{E}-05$ \\
$\mathrm{Cm}-244$ & 0.86 & 0.004 & $1.23 \mathrm{E}-05$ \\
$\mathrm{Cm}-246$ & 0.86 & 0.004 & $1.23 \mathrm{E}-05$ \\
$\mathrm{Co}-60$ & 0.86 & 0.004 & $1.23 \mathrm{E}-05$ \\
$\mathrm{Cs}-137$ & 0.86 & 0.004 & $1.23 \mathrm{E}-05$ \\
$\mathrm{~Np}-237$ & 0.86 & 0.004 & $1.23 \mathrm{E}-05$ \\
$\mathrm{Pm}-147$ & 0.86 & 0.004 & $1.23 \mathrm{E}-05$ \\
$\mathrm{Pu}-238$ & 0.86 & 0.004 & $1.23 \mathrm{E}-05$ \\
$\mathrm{Pu}-239$ & 0.86 & 0.004 & $1.23 \mathrm{E}-05$ \\
$\mathrm{Pu}-240$ & 0.86 & 0.004 & $1.23 \mathrm{E}-05$ \\
$\mathrm{Pu}-241$ & 0.86 & 0.004 & $1.23 \mathrm{E}-05$ \\
$\mathrm{Pu}-242$ & 0.86 & 0.004 & $1.23 \mathrm{E}-05$ \\
$\mathrm{Sr}-90$ & 0.86 & 0.004 & $1.23 \mathrm{E}-05$ \\
Tc-99 & 0.86 & 0.004 & $1.23 \mathrm{E}-05$ \\
Th-232 & 0.86 & 0.004 & $1.23 \mathrm{E}-05$ \\
Tl-204 & 0.86 & 0.004 & $1.23 \mathrm{E}-05$ \\
$\mathrm{U}-235$ & 0.86 & 0.004 & $1.23 \mathrm{E}-05$ \\
$\mathrm{U}-238$ & 0.86 & 0.004 & $1.23 \mathrm{E}-05$ \\
\hline Referce
\end{tabular}

Reference: Thompson 1999c: Ingestion Pathway Transfer Factors for Particulates.

The estimate of external contamination of grain is from IAEA 364, Table VII, page 27. The soil depth $(20 \mathrm{~cm})$ and density $\left(1.4 \mathrm{~g} \mathrm{~cm}^{-3}\right)$ are combined to give an areal density of $280 \mathrm{~kg} \mathrm{~m}^{-2}$, consistent with IAEA 364 . 


\section{APPENDIX G. DAIRY PRODUCT TRANSFER FACTORS}

Table G-1 lists the transfer factors for contamination of dairy products.

Table G-1. Contamination of Dairy Products

\begin{tabular}{|c|c|c|c|c|c|}
\hline Nuclide & ${ }_{\mathrm{i}} \mathrm{F}^{\mathrm{m}}$ (milk) $\mathrm{d} / \mathrm{L}$ & $\mathrm{r}$ & $\mathrm{Y}_{\mathrm{v}} \mathrm{kg} / \mathrm{m}^{2}$ wet & $\mathrm{Q}_{\mathrm{F}} \mathrm{kg} / \mathrm{d}$ (wet) & $\mathrm{T}_{\text {milk }} \mathrm{m}^{2} / \mathrm{L}$ \\
\hline Am-241 & $1.50 \mathrm{E}-06$ & 0.5 & 1.8 & 29.12 & $1.21 \mathrm{E}-05$ \\
\hline Am-243 & $1.50 \mathrm{E}-06$ & 0.5 & 1.8 & 29.12 & $1.21 \mathrm{E}-05$ \\
\hline Ba-133 & 4.80E-04 & 0.5 & 1.8 & 29.12 & $3.88 \mathrm{E}-03$ \\
\hline Ce-144 & $3.00 \mathrm{E}-05$ & 0.5 & 1.8 & 29.12 & $2.43 \mathrm{E}-04$ \\
\hline Cf-249 & 2.00E-06 & 0.5 & 1.8 & 29.12 & $1.62 \mathrm{E}-05$ \\
\hline Cf-252 & 2.00E-06 & 0.5 & 1.8 & 29.12 & $1.62 \mathrm{E}-05$ \\
\hline $\mathrm{Cm}-244$ & 2.00E-06 & 0.5 & 1.8 & 29.12 & $1.62 \mathrm{E}-05$ \\
\hline $\mathrm{Cm}-246$ & 2.00E-06 & 0.5 & 1.8 & 29.12 & $1.62 \mathrm{E}-05$ \\
\hline Co-60 & $3.00 \mathrm{E}-04$ & 0.5 & 1.8 & 29.12 & $2.43 \mathrm{E}-03$ \\
\hline Cs-137 & $7.90 \mathrm{E}-03$ & 0.5 & 1.8 & 29.12 & $6.39 \mathrm{E}-02$ \\
\hline Np-237 & $5.00 \mathrm{E}-06$ & 0.5 & 1.8 & 29.12 & $4.04 \mathrm{E}-05$ \\
\hline Pm-147 & $6.00 \mathrm{E}-05$ & 0.5 & 1.8 & 29.12 & $4.85 \mathrm{E}-04$ \\
\hline $\mathrm{Pu}-238$ & $1.10 \mathrm{E}-06$ & 0.5 & 1.8 & 29.12 & $8.90 \mathrm{E}-06$ \\
\hline $\mathrm{Pu}-239$ & $1.10 \mathrm{E}-06$ & 0.5 & 1.8 & 29.12 & $8.90 \mathrm{E}-06$ \\
\hline $\mathrm{Pu}-240$ & $1.10 \mathrm{E}-06$ & 0.5 & 1.8 & 29.12 & $8.90 \mathrm{E}-06$ \\
\hline $\mathrm{Pu}-241$ & $1.10 \mathrm{E}-06$ & 0.5 & 1.8 & 29.12 & $8.90 \mathrm{E}-06$ \\
\hline $\mathrm{Pu}-242$ & $1.10 \mathrm{E}-06$ & 0.5 & 1.8 & 29.12 & $8.90 \mathrm{E}-06$ \\
\hline Sr-90 & $2.80 \mathrm{E}-03$ & 0.5 & 1.8 & 29.12 & $2.26 \mathrm{E}-02$ \\
\hline Tc-99 & $2.30 \mathrm{E}-05$ & 0.5 & 1.8 & 29.12 & $1.86 \mathrm{E}-04$ \\
\hline Th-232 & 5.00E-06 & 0.5 & 1.8 & 29.12 & 4.04E-05 \\
\hline Tl-204 & 3.00E-03 & 0.5 & 1.8 & 29.12 & $2.43 \mathrm{E}-02$ \\
\hline U-235 & $4.00 \mathrm{E}-04$ & 0.5 & 1.8 & 29.12 & $3.24 \mathrm{E}-03$ \\
\hline U-238 & $4.00 \mathrm{E}-04$ & 0.5 & 1.8 & 29.12 & $3.24 \mathrm{E}-03$ \\
\hline
\end{tabular}

${ }_{i} \mathrm{~F}^{\mathrm{m}}$ is the average fraction of a cow's daily intake of radionuclide $i$ that appears in each liter of milk. $\mathrm{i}^{\mathrm{m}}$ has units of $\mathrm{Bq} \mathrm{L}^{-1}$ of milk per $\mathrm{Bq}$ day ${ }^{-1}$ consumed by the cow, or $\mathrm{d} \mathrm{L}^{-1}$. Most coefficients are from Table XII of IAEA 364. Coefficients for nuclides not listed in IAEA 364 are from NCRP 123. Shaded bold values indicate values from NCRP 123, Table 5.2. The value for cobalt corresponds to that for the organic form, which is the most limiting.

A deposition fraction "r" of 0.5 is given on page 13 of Shleien and Chiacchierini (1982), and is adopted as the value for pasture following an acute release of particulates in the following calculation. The SRS-specific agricultural productivity per unit area (measured in wet weight) $\left(Y_{v}\right)$ for the grass-cow-milk pathway is $1.8 \mathrm{~kg} \mathrm{~m}^{-2}$ (Hamby 1991).

The total consumption rate (wet weight per day) of forage consumed by a dairy cow is $52 \mathrm{~kg} \mathrm{~d}^{-1}$ (Hamby 1991). The SRS-specific fraction of intake from pasture is 0.56 (Hamby 1991). The product of these factors results in a daily consumption rate of contaminated forage $\left(\mathrm{Q}_{\mathrm{F}}\right)$ of $29.12 \mathrm{~kg} \mathrm{~d}^{-1}$. 


\section{APPENDIX H. EGG CONTENTS TRANSFER FACTORS}

Table H-1 lists the transfer factors for contamination of egg contents.

Table H-1. Contamination of Egg Contents

\begin{tabular}{|c|c|c|c|c|c|}
\hline Nuclide & ${ }_{\mathrm{i}} \mathrm{F}^{\mathrm{e}}(\operatorname{eggs}) \mathrm{d} / \mathrm{kg}$ & $\mathrm{r}$ & $\mathrm{Y}_{\mathrm{v}} \mathrm{kg} / \mathrm{m}^{2}$ wet & $\mathrm{Q}_{\mathrm{F}} \mathrm{kg} / \mathrm{d}$ (wet) & $\mathrm{T}_{\text {eggs }} \mathrm{m}^{2} / \mathrm{kg}$ \\
\hline Am-241 & $4.00 \mathrm{E}-03$ & 0.2 & 0.7 & 0.116 & $1.33 \mathrm{E}-04$ \\
\hline Am-243 & 4.00E-03 & 0.2 & 0.7 & 0.116 & $1.33 \mathrm{E}-04$ \\
\hline Ba-133 & $9.00 \mathrm{E}-01$ & 0.2 & 0.7 & 0.116 & $2.98 \mathrm{E}-02$ \\
\hline $\mathrm{Ce}-144$ & $9.00 \mathrm{E}-05$ & 0.2 & 0.7 & 0.116 & $2.98 \mathrm{E}-06$ \\
\hline Cf-249 & & 0.2 & 0.7 & 0.116 & \\
\hline Cf-252 & & 0.2 & 0.7 & 0.116 & \\
\hline $\mathrm{Cm}-244$ & & 0.2 & 0.7 & 0.116 & \\
\hline $\mathrm{Cm}-246$ & & 0.2 & 0.7 & 0.116 & \\
\hline Co-60 & $1.00 \mathrm{E}-01$ & 0.2 & 0.7 & 0.116 & $3.31 \mathrm{E}-03$ \\
\hline Cs-137 & $4.00 \mathrm{E}-01$ & 0.2 & 0.7 & 0.116 & $1.33 \mathrm{E}-02$ \\
\hline Np-237 & & 0.2 & 0.7 & 0.116 & \\
\hline Pm-147 & $2.00 \mathrm{E}-02$ & 0.2 & 0.7 & 0.116 & $6.63 \mathrm{E}-04$ \\
\hline $\mathrm{Pu}-238$ & $5.00 \mathrm{E}-04$ & 0.2 & 0.7 & 0.116 & $1.66 \mathrm{E}-05$ \\
\hline Pu-239 & $5.00 \mathrm{E}-04$ & 0.2 & 0.7 & 0.116 & $1.66 \mathrm{E}-05$ \\
\hline $\mathrm{Pu}-240$ & $5.00 \mathrm{E}-04$ & 0.2 & 0.7 & 0.116 & $1.66 \mathrm{E}-05$ \\
\hline $\mathrm{Pu}-241$ & $5.00 \mathrm{E}-04$ & 0.2 & 0.7 & 0.116 & $1.66 \mathrm{E}-05$ \\
\hline $\mathrm{Pu}-242$ & $5.00 \mathrm{E}-04$ & 0.2 & 0.7 & 0.116 & $1.66 \mathrm{E}-05$ \\
\hline Sr-90 & $2.00 \mathrm{E}-01$ & 0.2 & 0.7 & 0.116 & $6.63 \mathrm{E}-03$ \\
\hline Tc-99 & 3 & 0.2 & 0.7 & 0.116 & $9.94 \mathrm{E}-02$ \\
\hline Th-232 & & 0.2 & 0.7 & 0.116 & \\
\hline Tl-204 & & 0.2 & 0.7 & 0.116 & \\
\hline U-235 & 1 & 0.2 & 0.7 & 0.116 & $3.31 \mathrm{E}-02$ \\
\hline U-238 & 1 & 0.2 & 0.7 & 0.116 & $3.31 \mathrm{E}-02$ \\
\hline
\end{tabular}

Reference: Thompson 1999c: Ingestion Pathway Transfer Factors for Particulates.

${ }_{\mathrm{i}} \mathrm{F}_{\mathrm{e}}$ values are from IAEA 364, Table XX, page 41.

"r" values are from RG 1.109, page 68.

"Y ${ }_{\mathrm{v}}$ " values are from Hamby 1991.

Laying hens have a consumption rate of dry matter of $0.1 \mathrm{~kg} \mathrm{~d}^{-1}$ (IAEA (1994) Table XI, page 33). Dry weight contents of cereals (assumed to be representative of grain) are presented in IAEA (1994), Table $\mathrm{V}$, page 15 . The average dry weight content of cereals is about $86 \%$, so the wet consumption rate is $\left(0.1 \mathrm{~kg} \mathrm{~d}^{-1} / 0.86\right)=0.116 \mathrm{~kg} \mathrm{~d}^{-1}$. 


\section{APPENDIX I. BEEF TRANSFER FACTORS}

Table I-1 lists the transfer factors for contamination of beef.

Table I-1. Contamination of Beef

\begin{tabular}{|c|c|c|c|c|c|}
\hline Nuclide & ${ }_{\mathrm{i}} \mathrm{F}^{\mathrm{f}} \mathrm{d} / \mathrm{kg}$ & $\mathrm{r}$ & $\mathrm{Y}_{\mathrm{v}} \mathrm{kg} / \mathrm{m}^{2}$ wet & $\mathrm{Q}_{\mathrm{F}} \mathrm{kg} / \mathrm{d}$ & $\mathrm{T} \mathrm{m}^{2} / \mathrm{kg}$ \\
\hline Am-241 & $4.00 \mathrm{E}-05$ & 0.5 & 1.8 & 27 & $3.00 \mathrm{E}-04$ \\
\hline Am-243 & 4.00E-05 & 0.5 & 1.8 & 27 & $3.00 \mathrm{E}-04$ \\
\hline Ba-133 & $2.00 \mathrm{E}-04$ & 0.5 & 1.8 & 27 & $1.50 \mathrm{E}-03$ \\
\hline Ce-144 & $2.00 \mathrm{E}-05$ & 0.5 & 1.8 & 27 & $1.50 \mathrm{E}-04$ \\
\hline Cf-249 & 6.00E-05 & 0.5 & 1.8 & 27 & $4.50 \mathrm{E}-04$ \\
\hline Cf- 252 & 6.00E-05 & 0.5 & 1.8 & 27 & $4.50 \mathrm{E}-04$ \\
\hline $\mathrm{Cm}-244$ & 2.00E-05 & 0.5 & 1.8 & 27 & $1.50 \mathrm{E}-04$ \\
\hline $\mathrm{Cm}-246$ & 2.00E-05 & 0.5 & 1.8 & 27 & $1.50 \mathrm{E}-04$ \\
\hline Co-60 & $1.00 \mathrm{E}-02$ & 0.5 & 1.8 & 27 & $7.50 \mathrm{E}-02$ \\
\hline Cs- 137 & $5.00 \mathrm{E}-02$ & 0.5 & 1.8 & 27 & $3.75 \mathrm{E}-01$ \\
\hline $\mathrm{Np}-237$ & $1.00 \mathrm{E}-03$ & 0.5 & 1.8 & 27 & $7.50 \mathrm{E}-03$ \\
\hline Pm-147 & 2.00E-03 & 0.5 & 1.8 & 27 & $1.50 \mathrm{E}-02$ \\
\hline $\mathrm{Pu}-238$ & $1.00 \mathrm{E}-05$ & 0.5 & 1.8 & 27 & $7.50 \mathrm{E}-05$ \\
\hline $\mathrm{Pu}-239$ & $1.00 \mathrm{E}-05$ & 0.5 & 1.8 & 27 & $7.50 \mathrm{E}-05$ \\
\hline $\mathrm{Pu}-240$ & $1.00 \mathrm{E}-05$ & 0.5 & 1.8 & 27 & $7.50 \mathrm{E}-05$ \\
\hline $\mathrm{Pu}-241$ & $1.00 \mathrm{E}-05$ & 0.5 & 1.8 & 27 & $7.50 \mathrm{E}-05$ \\
\hline $\mathrm{Pu}-242$ & $1.00 \mathrm{E}-05$ & 0.5 & 1.8 & 27 & $7.50 \mathrm{E}-05$ \\
\hline Sr-90 & $8.00 \mathrm{E}-03$ & 0.5 & 1.8 & 27 & $6.00 \mathrm{E}-02$ \\
\hline Tc-99 & $1.00 \mathrm{E}-06$ & 0.5 & 1.8 & 27 & $7.50 \mathrm{E}-06$ \\
\hline Th-232 & 1.00E-04 & 0.5 & 1.8 & 27 & $7.50 \mathrm{E}-04$ \\
\hline Tl-204 & 2.00E-02 & 0.5 & 1.8 & 27 & $1.50 \mathrm{E}-01$ \\
\hline U-235 & $3.00 \mathrm{E}-04$ & 0.5 & 1.8 & 27 & $2.25 \mathrm{E}-03$ \\
\hline U-238 & $3.00 \mathrm{E}-04$ & 0.5 & 1.8 & 27 & $2.25 \mathrm{E}-03$ \\
\hline
\end{tabular}

Reference: Thompson 1999c: Ingestion Pathway Transfer Factors for Particulates.

${ }_{i} \mathrm{~F}^{\mathrm{f}}$ values are from IAEA (1994), Table XV (preferred) and NCRP 123, Table 5.2 (shaded bold).

The agricultural production rate $Y_{\mathrm{v}}$ is measured in wet weight. An SRS-specific value of $1.8 \mathrm{~kg}$ $\mathrm{m}^{-2}$ (wet weight of pasture grass per unit area) is chosen for meat calculations (Hamby 1991). An interception fraction $r$ for pasture of 0.5 is assumed.

The site-specific total wet forage consumption rate for beef is $36 \mathrm{~kg} \mathrm{~d}^{-1}$ (Hamby 1991). The SRS-specific value for the fraction of intake from pasture for beef is 0.75 (Hamby 1991). The product of the total consumption rate and the fraction of intake from pasture gives a contaminated forage consumption rate $\left(\mathrm{Q}_{F}\right)$ of $27 \mathrm{~kg} \mathrm{~d}^{-1}$. 


\section{APPENDIX J. VEAL TRANSFER FACTORS}

Table J-1 lists the transfer factors for contamination of veal.

Table J-1. Contamination of Veal

\begin{tabular}{lccccc}
\hline Nuclide & ${ }_{\mathrm{i}} \mathrm{F}^{\mathrm{f}}$ Veal & $\mathrm{r}$ & $\mathrm{Y}_{\mathrm{v}} \mathrm{kg} / \mathrm{m}^{2}$ wet & $\mathrm{Q}_{\mathrm{F}} \mathrm{kg} / \mathrm{d}$ & $\mathrm{T}_{\text {veal }} \mathrm{m}^{2} / \mathrm{kg}$ \\
\hline Am-241 & $1.00 \mathrm{E}-03$ & 0.5 & 1.8 & 8.6 & $2.39 \mathrm{E}-03$ \\
$\mathrm{Am}-243$ & $1.00 \mathrm{E}-03$ & 0.5 & 1.8 & 8.6 & $2.39 \mathrm{E}-03$ \\
$\mathrm{Ba}-133$ & $*$ & 0.5 & 1.8 & 8.6 & $*$ \\
$\mathrm{Ce}-144$ & $*$ & 0.5 & 1.8 & 8.6 & $*$ \\
$\mathrm{vCf}-249$ & $*$ & 0.5 & 1.8 & 8.6 & $*$ \\
$\mathrm{Cf}-252$ & $*$ & 0.5 & 1.8 & 8.6 & $*$ \\
$\mathrm{Cm}-244$ & $*$ & 0.5 & 1.8 & 8.6 & $*$ \\
$\mathrm{Cm}-246$ & $*$ & 0.5 & 1.8 & 8.6 & $*$ \\
$\mathrm{Co}-60$ & $*$ & 0.5 & 1.8 & 8.6 & $*$ \\
$\mathrm{Cs}-137$ & $2.00 \mathrm{E}-01$ & 0.5 & 1.8 & 8.6 & $4.78 \mathrm{E}-01$ \\
$\mathrm{~Np}-237$ & $*$ & 0.5 & 1.8 & 8.6 & $*$ \\
$\mathrm{Pm}-147$ & $*$ & 0.5 & 1.8 & 8.6 & $*$ \\
$\mathrm{Pu}-238$ & $1.00 \mathrm{E}-03$ & 0.5 & 1.8 & 8.6 & $2.39 \mathrm{E}-03$ \\
$\mathrm{Pu}-239$ & $1.00 \mathrm{E}-03$ & 0.5 & 1.8 & 8.6 & $2.39 \mathrm{E}-03$ \\
$\mathrm{Pu}-240$ & $1.00 \mathrm{E}-03$ & 0.5 & 1.8 & 8.6 & $2.39 \mathrm{E}-03$ \\
$\mathrm{Pu}-241$ & $1.00 \mathrm{E}-03$ & 0.5 & 1.8 & 8.6 & $2.39 \mathrm{E}-03$ \\
$\mathrm{Pu}-242$ & $1.00 \mathrm{E}-03$ & 0.5 & 1.8 & 8.6 & $2.39 \mathrm{E}-03$ \\
$\mathrm{Sr}-90$ & $1.00 \mathrm{E}-01$ & 0.5 & 1.8 & 8.6 & $2.39 \mathrm{E}-01$ \\
$\mathrm{Tc}-99$ & $*$ & 0.5 & 1.8 & 8.6 & $*$ \\
$\mathrm{Th}-232$ & $*$ & 0.5 & 1.8 & 8.6 & $*$ \\
$\mathrm{Tl}-204$ & $*$ & 0.5 & 1.8 & 8.6 & $*$ \\
$\mathrm{U}-235$ & $*$ & 0.5 & 1.8 & 8.6 & $*$ \\
$\mathrm{U}-238$ & $*$ & 0.5 & 1.8 & 8.6 & $*$ \\
\hline & $* 396$ & & & $*$ \\
\hline
\end{tabular}

* factors not available

Reference: Thompson 1999c: Ingestion Pathway Transfer Factors for Particulates.

${ }_{\mathrm{i}} \mathrm{F}^{\mathrm{f}}$ values are from IAEA (1994), Table XV.

The agricultural production rate $Y_{\mathrm{v}}$ is measured in wet weight. An SRS-specific value of $1.8 \mathrm{~kg} \mathrm{~m}^{-2}$ (wet weight of pasture grass per unit area) is chosen for meat calculations (Hamby 1991). An interception fraction $r$ for pasture of 0.5 is assumed.

The quantities (dry weight) of forage consumed are values from IAEA (1994), Table XI, page 33. Wet forage consumption rates $\left(\mathrm{Q}_{\mathrm{F}}\right)$ are 4.5 times the dry consumption rates per Table 5.16, page 5-48 of Till and Meyer (1983). All forage consumed by the animal is assumed to be contaminated. 


\section{APPENDIX K. SHEEP TRANSFER FACTORS}

Table K-1 lists the transfer factors for contamination of sheep.

Table K-1. Contamination of Sheep

\begin{tabular}{lccccc}
\hline Nuclide & ${ }_{\mathrm{i}} \mathrm{F}^{\mathrm{f}}$ Sheep & $\mathrm{r}$ & $\mathrm{Y}_{\mathrm{v}} \mathrm{kg} / \mathrm{m}^{2}$ wet & $\mathrm{Q}_{\mathrm{F}} \mathrm{kg} / \mathrm{d}$ & $\mathrm{T}_{\text {sheep }} \mathrm{m}^{2} / \mathrm{kg}$ \\
\hline $\mathrm{Am}-241$ & $2.00 \mathrm{E}-04$ & 0.5 & 1.8 & 5.9 & $3.28 \mathrm{E}-04$ \\
$\mathrm{Am}-243$ & $2.00 \mathrm{E}-04$ & 0.5 & 1.8 & 5.9 & $3.28 \mathrm{E}-04$ \\
$\mathrm{Ba}-133$ & $*$ & 0.5 & 1.8 & 5.9 & $*$ \\
$\mathrm{Ce}-144$ & $2.00 \mathrm{E}-04$ & 0.5 & 1.8 & 5.9 & $3.28 \mathrm{E}-04$ \\
$\mathrm{Cf}-249$ & $*$ & 0.5 & 1.8 & 5.9 & $*$ \\
$\mathrm{Cf}-252$ & $*$ & 0.5 & 1.8 & 5.9 & $*$ \\
$\mathrm{Cm}-244$ & $*$ & 0.5 & 1.8 & 5.9 & $*$ \\
$\mathrm{Cm}-246$ & $*$ & 0.5 & 1.8 & 5.9 & $*$ \\
$\mathrm{Co}-60$ & $6.20 \mathrm{E}-02$ & 0.5 & 1.8 & 5.9 & $1.02 \mathrm{E}-01$ \\
$\mathrm{Cs}-137$ & $1.70 \mathrm{E}-01$ & 0.5 & 1.8 & 5.9 & $2.79 \mathrm{E}-01$ \\
$\mathrm{~Np}-237$ & $*$ & 0.5 & 1.8 & 5.9 & $*$ \\
$\mathrm{Pm}-147$ & $*$ & 0.5 & 1.8 & 5.9 & $*$ \\
$\mathrm{Pu}-238$ & $9.40 \mathrm{E}-05$ & 0.5 & 1.8 & 5.9 & $1.54 \mathrm{E}-04$ \\
$\mathrm{Pu}-239$ & $9.40 \mathrm{E}-05$ & 0.5 & 1.8 & 5.9 & $1.54 \mathrm{E}-04$ \\
$\mathrm{Pu}-240$ & $9.40 \mathrm{E}-05$ & 0.5 & 1.8 & 5.9 & $1.54 \mathrm{E}-04$ \\
$\mathrm{Pu}-241$ & $9.40 \mathrm{E}-05$ & 0.5 & 1.8 & 5.9 & $1.54 \mathrm{E}-04$ \\
$\mathrm{Pu}-242$ & $9.40 \mathrm{E}-05$ & 0.5 & 1.8 & 5.9 & $1.54 \mathrm{E}-04$ \\
$\mathrm{Sr}-90$ & $4.00 \mathrm{E}-02$ & 0.5 & 1.8 & 5.9 & $6.56 \mathrm{E}-02$ \\
$\mathrm{Tc}-99$ & $*$ & 0.5 & 1.8 & 5.9 & $*$ \\
$\mathrm{Th}-232$ & $*$ & 0.5 & 1.8 & 5.9 & $*$ \\
$\mathrm{Tl}-204$ & $*$ & 0.5 & 1.8 & 5.9 & $*$ \\
$\mathrm{U}-235$ & $*$ & 0.5 & 1.8 & 5.9 & $*$ \\
$\mathrm{U}-238$ & $*$ & 0.5 & 1.8 & 5.9 & $*$ \\
\hline
\end{tabular}

* factors not available

Reference: Thompson 1999c: Ingestion Pathway Transfer Factors for Particulates.

${ }_{i} \mathrm{~F}^{\mathrm{f}}$ values are from IAEA (1994), Table XVI.

The agricultural production rate $Y_{\mathrm{v}}$ is measured in wet weight. An SRS-specific value of $1.8 \mathrm{~kg} \mathrm{~m}^{-2}$ (wet weight of pasture grass per unit area) is chosen for meat calculations (Hamby 1991). An interception fraction $r$ for pasture of 0.5 is assumed.

The quantities (dry weight) of forage consumed are values from IAEA (1994), Table XI, page 33. Wet forage consumption rates $\left(\mathrm{Q}_{\mathrm{F}}\right)$ are 4.5 times the dry consumption rates per Table 5.16, page 5-48 of Till and Meyer (1983). All forage consumed by the animal is assumed to be contaminated. 


\section{APPENDIX L. LAMB TRANSFER FACTORS}

Table L-1 lists the transfer factors for contamination of lamb.

Table L-1. Contamination of Lamb

\begin{tabular}{lccccc}
\hline Nuclide & ${ }_{\mathrm{i}} \mathrm{F}^{\mathrm{f}}$ Lamb d/kg & $\mathrm{r}$ & $\mathrm{Y}_{\mathrm{v}} \mathrm{kg} / \mathrm{m}^{2}$ wet & $\mathrm{Q}_{\mathrm{F}} \mathrm{kg} / \mathrm{d}$ & $\mathrm{T}_{\text {lamb }} \mathrm{m}^{2} / \mathrm{kg}$ \\
\hline Am-241 & $4.10 \mathrm{E}-03$ & 0.5 & 1.8 & 5 & $5.69 \mathrm{E}-03$ \\
$\mathrm{Am}-243$ & $4.10 \mathrm{E}-03$ & 0.5 & 1.8 & 5 & $5.69 \mathrm{E}-03$ \\
$\mathrm{Ba}-133$ & $*$ & 0.5 & 1.8 & 5 & $*$ \\
$\mathrm{Ce}-144$ & $*$ & 0.5 & 1.8 & 5 & $*$ \\
$\mathrm{Cf}-249$ & $*$ & 0.5 & 1.8 & 5 & $*$ \\
$\mathrm{Cf}-252$ & $*$ & 0.5 & 1.8 & 5 & $*$ \\
$\mathrm{Cm}-244$ & $*$ & 0.5 & 1.8 & 5 & $*$ \\
$\mathrm{Cm}-246$ & $*$ & 0.5 & 1.8 & 5 & $*$ \\
$\mathrm{Co}-60$ & $*$ & 0.5 & 1.8 & 5 & $*$ \\
$\mathrm{Cs}-137$ & $4.90 \mathrm{E}-01$ & 0.5 & 1.8 & 5 & $6.81 \mathrm{E}-01$ \\
$\mathrm{~Np}-237$ & $*$ & 0.5 & 1.8 & 5 & $*$ \\
$\mathrm{Pm}-147$ & $*$ & 0.5 & 1.8 & 5 & $*$ \\
Pu-238 & $3.10 \mathrm{E}-03$ & 0.5 & 1.8 & 5 & $4.31 \mathrm{E}-03$ \\
$\mathrm{Pu}-239$ & $3.10 \mathrm{E}-03$ & 0.5 & 1.8 & 5 & $4.31 \mathrm{E}-03$ \\
$\mathrm{Pu}-240$ & $3.10 \mathrm{E}-03$ & 0.5 & 1.8 & 5 & $4.31 \mathrm{E}-03$ \\
Pu-241 & $3.10 \mathrm{E}-03$ & 0.5 & 1.8 & 5 & $4.31 \mathrm{E}-03$ \\
$\mathrm{Pu}-242$ & $3.10 \mathrm{E}-03$ & 0.5 & 1.8 & 5 & $4.31 \mathrm{E}-03$ \\
Sr-90 & $3.30 \mathrm{E}-01$ & 0.5 & 1.8 & 5 & $4.58 \mathrm{E}-01$ \\
Tc-99 & $*$ & 0.5 & 1.8 & 5 & $*$ \\
Th-232 & $*$ & 0.5 & 1.8 & 5 & $*$ \\
Tl-204 & $*$ & 0.5 & 1.8 & 5 & $*$ \\
$\mathrm{U}-235$ & $*$ & 0.5 & 1.8 & 5 & $*$ \\
$\mathrm{U}-238$ & $*$ & 0.5 & 1.8 & 5 & $*$ \\
\hline
\end{tabular}

* factors not available

Reference: Thompson 1999c: Ingestion Pathway Transfer Factors for Particulates.

${ }_{i} \mathrm{~F}^{\mathrm{f}}$ values are from IAEA (1994), Table XVI.

The agricultural production rate $Y_{\mathrm{v}}$ is measured in wet weight. An SRS-specific value of $1.8 \mathrm{~kg} \mathrm{~m}^{-2}$ (wet weight of pasture grass per unit area) is chosen for meat calculations (Hamby 1991). An interception fraction $r$ for pasture of 0.5 is assumed.

The quantities (dry weight) of forage consumed are values from IAEA (1994), Table XI, page 33. Wet forage consumption rates $\left(\mathrm{Q}_{\mathrm{F}}\right)$ are 4.5 times the dry consumption rates per Table 5.16, page 5-48 of Till and Meyer (1983). All forage consumed by the animal is assumed to be contaminated. 


\section{APPENDIX M. PORK TRANSFER FACTORS}

Table M-1 lists the transfer factors for contamination of pork.

Table M-1. Contamination of Pork

\begin{tabular}{lccccc}
\hline Nuclide & ${ }_{\mathrm{i}} \mathrm{F}^{\mathrm{f}}$ Pork d/kg & $\mathrm{r}$ & $\mathrm{Y}_{\mathrm{v}} \mathrm{kg} / \mathrm{m}^{2}$ wet & $\mathrm{Q}_{\mathrm{F}} \mathrm{kg} / \mathrm{d}$ & $\mathrm{T}_{\text {pork }} \mathrm{m}^{2} / \mathrm{kg}$ \\
\hline $\mathrm{Am}-241$ & $1.70 \mathrm{E}-04$ & 0.5 & 1.8 & 11 & $5.19 \mathrm{E}-04$ \\
$\mathrm{Am}-243$ & $1.70 \mathrm{E}-04$ & 0.5 & 1.8 & 11 & $5.19 \mathrm{E}-04$ \\
$\mathrm{Ba}-133$ & $*$ & 0.5 & 1.8 & 11 & $*$ \\
$\mathrm{Ce}-144$ & $1.00 \mathrm{E}-04$ & 0.5 & 1.8 & 11 & $3.06 \mathrm{E}-04$ \\
$\mathrm{Cf}-249$ & $*$ & 0.5 & 1.8 & 11 & $*$ \\
$\mathrm{Cf}-252$ & $*$ & 0.5 & 1.8 & 11 & $*$ \\
$\mathrm{Cm}-244$ & $*$ & 0.5 & 1.8 & 11 & $*$ \\
$\mathrm{Cm}-246$ & $*$ & 0.5 & 1.8 & 11 & $*$ \\
$\mathrm{Co}-60$ & $2.00 \mathrm{E}-03$ & 0.5 & 1.8 & 11 & $6.11 \mathrm{E}-03$ \\
$\mathrm{Cs}-137$ & $2.40 \mathrm{E}-01$ & 0.5 & 1.8 & 11 & $7.33 \mathrm{E}-01$ \\
$\mathrm{~Np}-237$ & $*$ & 0.5 & 1.8 & 11 & $*$ \\
$\mathrm{Pm}-147$ & $*$ & 0.5 & 1.8 & 11 & $*$ \\
$\mathrm{Pu}-238$ & $8.00 \mathrm{E}-05$ & 0.5 & 1.8 & 11 & $2.44 \mathrm{E}-04$ \\
$\mathrm{Pu}-239$ & $8.00 \mathrm{E}-05$ & 0.5 & 1.8 & 11 & $2.44 \mathrm{E}-04$ \\
$\mathrm{Pu}-240$ & $8.00 \mathrm{E}-05$ & 0.5 & 1.8 & 11 & $2.44 \mathrm{E}-04$ \\
$\mathrm{Pu}-241$ & $8.00 \mathrm{E}-05$ & 0.5 & 1.8 & 11 & $2.44 \mathrm{E}-04$ \\
$\mathrm{Pu}-242$ & $8.00 \mathrm{E}-05$ & 0.5 & 1.8 & 11 & $2.44 \mathrm{E}-04$ \\
$\mathrm{Sr}-90$ & $4.00 \mathrm{E}-02$ & 0.5 & 1.8 & 11 & $1.22 \mathrm{E}-01$ \\
$\mathrm{Tc}-99$ & $1.50 \mathrm{E}-04$ & 0.5 & 1.8 & 11 & $4.58 \mathrm{E}-04$ \\
Th-232 & $*$ & 0.5 & 1.8 & 11 & $*$ \\
$\mathrm{Tl}-204$ & $*$ & 0.5 & 1.8 & 11 & $*$ \\
$\mathrm{U}-235$ & $6.20 \mathrm{E}-02$ & 0.5 & 1.8 & 11 & $1.89 \mathrm{E}-01$ \\
$\mathrm{U}-238$ & $6.20 \mathrm{E}-02$ & 0.5 & 1.8 & 11 & $1.89 \mathrm{E}-01$ \\
\hline
\end{tabular}

* factors not available

Reference: Thompson 1999c: Ingestion Pathway Transfer Factors for Particulates.

${ }_{i} \mathrm{~F}^{\mathrm{f}}$ values are from IAEA (1994), Table XVIII.

The agricultural production rate $Y_{\mathrm{v}}$ is measured in wet weight. An SRS-specific value of $1.8 \mathrm{~kg} \mathrm{~m}^{-2}$ (wet weight of pasture grass per unit area) is chosen for meat calculations (Hamby 1991). An interception fraction $r$ for pasture of 0.5 is assumed.

The quantities (dry weight) of forage consumed are values from IAEA (1994), Table XI, page 33. Wet forage consumption rates $\left(\mathrm{Q}_{\mathrm{F}}\right)$ are 4.5 times the dry consumption rates per Table 5.16, page 5-48 of Till and Meyer (1983). All forage consumed is assumed to be contaminated. 


\section{APPENDIX N. POULTRY TRANSFER FACTORS}

Table N-1 lists the transfer factors for contamination of poultry.

Table N-1. Contamination of Poultry

\begin{tabular}{lccccc}
\hline Nuclide & iF $^{\mathrm{f}}$ Poultry d/kg & $\mathrm{r}$ & $\mathrm{Y}_{\mathrm{v}} \mathrm{kg} / \mathrm{m}^{2}$ wet & $\mathrm{Q}_{\mathrm{F}} \mathrm{kg} / \mathrm{d}$ & $\mathrm{T}_{\text {poultry }} \mathrm{m}^{2} / \mathrm{kg}$ \\
\hline Am-241 & $6.00 \mathrm{E}-03$ & 0.5 & 1.8 & 0.315 & $5.25 \mathrm{E}-04$ \\
$\mathrm{Am}-243$ & $6.00 \mathrm{E}-03$ & 0.5 & 1.8 & 0.315 & $5.25 \mathrm{E}-04$ \\
$\mathrm{Ba}-133$ & $9.00 \mathrm{E}-03$ & 0.5 & 1.8 & 0.315 & $7.88 \mathrm{E}-04$ \\
$\mathrm{Ce}-144$ & $4.00 \mathrm{E}-03$ & 0.5 & 1.8 & 0.315 & $3.50 \mathrm{E}-04$ \\
$\mathrm{Cf}-249$ & $*$ & 0.5 & 1.8 & 0.315 & $*$ \\
$\mathrm{Cf}-252$ & $*$ & 0.5 & 1.8 & 0.315 & $*$ \\
$\mathrm{Cm}-244$ & $*$ & 0.5 & 1.8 & 0.315 & $*$ \\
$\mathrm{Cm}-246$ & $*$ & 0.5 & 1.8 & 0.315 & $*$ \\
$\mathrm{Co}-60$ & 2 & 0.5 & 1.8 & 0.315 & $1.75 \mathrm{E}-01$ \\
$\mathrm{Cs}-137$ & 10 & 0.5 & 1.8 & 0.315 & $8.75 \mathrm{E}-01$ \\
$\mathrm{~Np}-237$ & $*$ & 0.5 & 1.8 & 0.315 & $*$ \\
$\mathrm{Pm}-147$ & $2.00 \mathrm{E}-03$ & 0.5 & 1.8 & 0.315 & $1.75 \mathrm{E}-04$ \\
$\mathrm{Pu}-238$ & $3.00 \mathrm{E}-03$ & 0.5 & 1.8 & 0.315 & $2.63 \mathrm{E}-04$ \\
$\mathrm{Pu}-239$ & $3.00 \mathrm{E}-03$ & 0.5 & 1.8 & 0.315 & $2.63 \mathrm{E}-04$ \\
$\mathrm{Pu}-240$ & $3.00 \mathrm{E}-03$ & 0.5 & 1.8 & 0.315 & $2.63 \mathrm{E}-04$ \\
$\mathrm{Pu}-241$ & $3.00 \mathrm{E}-03$ & 0.5 & 1.8 & 0.315 & $2.63 \mathrm{E}-04$ \\
$\mathrm{Pu}-242$ & $3.00 \mathrm{E}-03$ & 0.5 & 1.8 & 0.315 & $2.63 \mathrm{E}-04$ \\
$\mathrm{Sr}-90$ & $8.00 \mathrm{E}-02$ & 0.5 & 1.8 & 0.315 & $7.00 \mathrm{E}-03$ \\
$\mathrm{Tc}-99$ & $3.00 \mathrm{E}-02$ & 0.5 & 1.8 & 0.315 & $2.63 \mathrm{E}-03$ \\
Th-232 & $*$ & 0.5 & 1.8 & 0.315 & $*$ \\
Tl-204 & $*$ & 0.5 & 1.8 & 0.315 & $*$ \\
$\mathrm{U}-235$ & 1 & 0.5 & 1.8 & 0.315 & $8.75 \mathrm{E}-02$ \\
$\mathrm{U}-238$ & 1 & 0.5 & 1.8 & 0.315 & $8.75 \mathrm{E}-02$ \\
\hline
\end{tabular}

* factors not available

Reference: Thompson 1999c: Ingestion Pathway Transfer Factors for Particulates.

${ }_{i} \mathrm{~F}^{\mathrm{f}}$ values are from IAEA (1994), Table XIX.

The agricultural production rate $Y_{\mathrm{v}}$ is measured in wet weight. An SRS-specific value of $1.8 \mathrm{~kg} \mathrm{~m}^{-2}$ (wet weight of pasture grass per unit area) is chosen for meat calculations (Hamby 1991). An interception fraction $r$ for pasture of 0.5 is assumed.

The quantities (dry weight) of forage consumed are values from IAEA (1994), Table XI, page 33. Wet forage consumption rates $\left(\mathrm{Q}_{\mathrm{F}}\right)$ are 4.5 times the dry consumption rates per Table 5.16, page 5-48 of Till and Meyer (1983). All forage consumed by the animal is assumed to be contaminated. 


\section{APPENDIX O. BEVERAGE TRANSFER FACTORS}

Table O-1 lists the transfer factors for contamination of beverages.

\section{Table 0-1. Contamination of Beverages}

\begin{tabular}{lc}
\hline Nuclide & $\mathrm{T}_{\text {water }}\left(\mathrm{m}^{2} / \mathrm{L}\right)$ \\
\hline Am-241 & 0.001 \\
Am-243 & 0.001 \\
Ba-133 & 0.001 \\
Ce-144 & 0.001 \\
Cf-249 & 0.001 \\
Cf-252 & 0.001 \\
Cm-244 & 0.001 \\
Cm-246 & 0.001 \\
Co-60 & 0.001 \\
Cs-137 & 0.001 \\
Np-237 & 0.001 \\
Pm-147 & 0.001 \\
Pu-238 & 0.001 \\
Pu-239 & 0.001 \\
Pu-240 & 0.001 \\
Pu-241 & 0.001 \\
Pu-242 & 0.001 \\
Sr-90 & 0.001 \\
Tc-99 & 0.001 \\
Th-232 & 0.001 \\
Tl-204 & 0.001 \\
U-235 & 0.001 \\
U-238 & 0.001 \\
\hline
\end{tabular}

Reference: Thompson 1999c: Ingestion Pathway Transfer Factors for Particulates.

A depth of water (d) of 1 meter is assumed. The density of water is $10^{3} \mathrm{~kg} \mathrm{~m}^{-3}$. 


\section{APPENDIX P. FISH TRANSFER FACTORS}

Table P-1 lists the transfer factors for contamination of fish.

Table P-1. Contamination of Fish

\begin{tabular}{|c|c|c|c|}
\hline Nuclide & $\mathrm{B}_{\mathrm{p}} \mathrm{L} / \mathrm{kg}$ & factor $T_{\text {water }}\left(\mathrm{m}^{2} / \mathrm{L}\right)$ & $\mathrm{T}_{\text {fish }} \mathrm{m}^{2} / \mathrm{kg}$ \\
\hline$\overline{A m-241}$ & 30 & 0.001 & 0.03 \\
\hline Am-243 & 30 & 0.001 & 0.03 \\
\hline Ba-133 & 4 & 0.001 & 0.004 \\
\hline Ce-144 & 30 & 0.001 & 0.03 \\
\hline Cf-249 & 25 & 0.001 & 0.025 \\
\hline Cf-252 & 25 & 0.001 & 0.025 \\
\hline $\mathrm{Cm}-244$ & 30 & 0.001 & 0.03 \\
\hline $\mathrm{Cm}-246$ & 30 & 0.001 & 0.03 \\
\hline Сo-60 & 300 & 0.001 & 0.3 \\
\hline Cs-137 & 2000 & 0.001 & 2 \\
\hline Np-237 & 30 & 0.001 & 0.03 \\
\hline Pm-147 & 30 & 0.001 & 0.03 \\
\hline $\mathrm{Pu}-238$ & 30 & 0.001 & 0.03 \\
\hline $\mathrm{Pu}-239$ & 30 & 0.001 & 0.03 \\
\hline $\mathrm{Pu}-240$ & 30 & 0.001 & 0.03 \\
\hline $\mathrm{Pu}-241$ & 30 & 0.001 & 0.03 \\
\hline $\mathrm{Pu}-242$ & 30 & 0.001 & 0.03 \\
\hline Sr-90 & 60 & 0.001 & 0.06 \\
\hline Tc-99 & 20 & 0.001 & 0.02 \\
\hline Th-232 & 100 & 0.001 & 0.1 \\
\hline Tl-204 & $1.00 \mathrm{E}+04$ & 0.001 & 10 \\
\hline U-235 & 10 & 0.001 & 0.01 \\
\hline U-238 & 10 & 0.001 & 0.01 \\
\hline
\end{tabular}

Reference: Thompson 1999c: Ingestion Pathway Transfer Factors for Particulates.

Concentration factors $\left(B_{p}\right)$ values are from IAEA (1994), Table XXII (preferred) and NCRP 123, Table 6.1 (shaded bold). Fish are assumed to live in stagnant water one meter deep. No sedimentation/precipitation of the contaminant is assumed. 


\section{APPENDIX Q. EXAMPLE PARTICULATE CALCULATION}

This appendix presents the steps in an example calculation for particulates. It follows the process outlined in the body of this report. The overall approach used to evaluate the impact of an atmospheric release of radionuclides on the food chain has been divided into several steps that follow radioactive material through the environment and food chain to man and are described in the body of this report. These steps follow the basic outline of Table 1 in the body of the report.

The analysis presented in this appendix is fully documented in Thompson (1999b) Ingestion Pathway Consequences of an H-Separations Coil and Tube Failure.

\section{METHOD}

The method used to determine Derived Response Levels (DRLs) is outlined below.

1. Determine the source terms (radionuclide-specific and total airborne releases).

2. Calculate the concentrations of each radionuclide in foodstuffs for a unit deposition of the total (as opposed to respirable) particulate mix.

3. For radionuclides with FDA (1998) Derived Intervention Levels (DILs), divide the DIL by the foodstuff concentration from a unit deposition. The DRL is the deposition that gives a DIL for a specific nuclide (group) and pathway.

4. Once a DRL is determined, ranges and areas affected may be predicted with a dispersion/deposition model such as HOTSPOT.

The first pathway step described in Table 1 of the main body of this report, involves quantifying the radioactive material released (i.e., the source term). Nuclide-specific source terms for this accident scenario were taken from a previous emergency preparedness hazards assessment (EPHA) evaluating the inhalation dose from plume passage. For consequence analyses when inhalation pathways are the primary concern, the respirable (aerodynamic diameters less than 10 microns) airborne release is used. For consequences involving the ingestion pathways, it is more appropriate to use the total (the sum of the respirable and nonrespirable) airborne release. In the specific case of this accident scenario, the respirable fraction (the respirable activity divided by the total airborne activity) is unity, so the respirable and total airborne activities are the same. The total source term is listed in Table Q-1. 


\section{Table Q-1. H-Separations total airborne source term}

\begin{tabular}{cc}
\hline Nuclide & $\begin{array}{c}\text { Airborne Release } \\
\text { (Ci) }\end{array}$ \\
\hline $\mathrm{Am}-241$ & $6.57 \mathrm{E}-01$ \\
$\mathrm{Pu}-238$ & $1.62 \mathrm{E}+00$ \\
$\mathrm{Pu}-239$ & $4.23 \mathrm{E}-03$ \\
$\mathrm{Pu}-240$ & $2.43 \mathrm{E}-01$ \\
$\mathrm{Pu}-241$ & $3.26 \mathrm{E}+01$ \\
$\mathrm{Pu}-242$ & $1.54 \mathrm{E}-02$ \\
Total & $3.51 \mathrm{E}+01$ \\
\hline
\end{tabular}

\section{Classification of release into FDA radionuclide groups}

The $\mathrm{Pu}-238+\mathrm{Pu}-239+\mathrm{Am}-241$ group is the only one of the five radionuclide groups that is represented. This group has a DIL of $2 \mathrm{~Bq} \mathrm{~kg}^{-1}$ (or $2 \mathrm{~Bq} \mathrm{~L}^{-1}$ for milk or water) The only one of the fifteen additional radionuclides evaluated in FDA (1998) that is in this source term is Pu-241. $\mathrm{Pu}-241$ has a DIL of $120 \mathrm{~Bq} \mathrm{~kg}^{-1}$. DILs for Pu-240 and Pu-242 are not given in FDA (1998).

\section{Evaluation of the deposition needed to exceed a DIL}

Assume a unit deposition of $1 \mathrm{~Bq} \mathrm{~m}^{-2}\left(2.70 \times 10^{-11} \mathrm{Ci} \mathrm{m}^{-2}\right)$ of the nuclide mix, and that all radionuclides deposit similarly. In this case, the relative concentrations of the deposited material will be the same as that released. The quantities of the individual radionuclides present for this unit deposition are given in Table Q-2.

\section{Table Q-2. Areal concentrations for a unit deposition}

\begin{tabular}{cc} 
Nuclide & $\begin{array}{c}\text { Areal concentration per unit deposition } \\
\left(\mathrm{Bq} \mathrm{m}{ }^{-2}\right)\end{array}$ \\
\hline $\mathrm{Am}-241$ & $1.87 \mathrm{E}-02$ \\
$\mathrm{Pu}-238$ & $4.61 \mathrm{E}-02$ \\
$\mathrm{Pu}-239$ & $1.20 \mathrm{E}-04$ \\
$\mathrm{Pu}-240$ & $6.92 \mathrm{E}-03$ \\
$\mathrm{Pu}-241$ & $9.28 \mathrm{E}-01$ \\
$\mathrm{Pu}-242$ & $4.38 \mathrm{E}-04$ \\
\hline
\end{tabular}

The concentrations in various foodstuffs due to this unit deposition may now be evaluated. The concentration of a particular radionuclide in a foodstuff is equal to the deposition times the (radionuclide-specific) overall transfer factor. Division of the DIL by the concentration in the foodstuff resulting from a unit deposition gives the deposition needed for a DIL. This process is presented in Tables Q-3 and Q-4 for the dairy pathway.

Aggregated transfer factors for plutonium and americium are taken from Appendix G. Plutonium and americium encompass all elements released in scenario 1-RD-2.35. 


\section{Table Q-3. Radionuclide concentration in milk per unit deposition of particulate mix}

\begin{tabular}{|c|c|c|c|c|c|}
\hline Nuclide & $\begin{array}{c}\text { Areal } \\
\text { concentration } \\
\text { per unit } \\
\text { deposition } \\
\left(\mathrm{Bq} \mathrm{m}^{-2}\right) \text { of } \\
\text { mix }\end{array}$ & $\begin{array}{c}\text { Aggregated } \\
\text { transfer } \\
\text { factor } \mathrm{T}_{\text {milk }} \\
\left(\mathrm{m}^{2} \mathrm{~L}^{-1}\right)\end{array}$ & $\begin{array}{l}\text { Concentration in } \\
\text { milk }\left(\mathrm{Bq} \mathrm{L}^{-1}\right) \text { per } \\
\text { unit deposition }\end{array}$ & $\begin{array}{l}\text { Radionuclide } \\
\text { Group } \\
\text { concentration } \\
\left(\mathrm{Bq} \mathrm{L}^{-1}\right)\end{array}$ & Radionuclide Group \\
\hline Am-241 & $1.87 \mathrm{E}-02$ & $1.21 \mathrm{E}-05$ & $2.27 \mathrm{E}-07$ & & \\
\hline $\mathrm{Pu}-238$ & 4.61E-02 & $8.90 \mathrm{E}-06$ & $4.10 \mathrm{E}-07$ & $6.38 \mathrm{E}-07$ & $\mathrm{Pu}-238+\mathrm{Pu}-239+$ \\
\hline Pu-239 & $1.20 \mathrm{E}-04$ & $8.90 \mathrm{E}-06$ & $1.07 \mathrm{E}-09$ & & Am-241 \\
\hline $\mathrm{Pu}-240$ & $6.92 \mathrm{E}-03$ & $8.90 \mathrm{E}-06$ & $6.15 \mathrm{E}-08$ & NA & NA \\
\hline $\mathrm{Pu}-241$ & $9.28 \mathrm{E}-01$ & $8.90 \mathrm{E}-06$ & $8.25 \mathrm{E}-06$ & $8.25 \mathrm{E}-06$ & $\mathrm{Pu}-241$ \\
\hline $\mathrm{Pu}-242$ & $4.38 \mathrm{E}-04$ & $8.90 \mathrm{E}-06$ & $3.90 \mathrm{E}-09$ & NA & NA \\
\hline
\end{tabular}

Table Q-4. Derived response levels for the milk pathway

\begin{tabular}{rccc}
\hline & $\begin{array}{c}\text { Radionuclide Group } \\
\text { concentration }\left(\mathrm{Bq} \mathrm{L}^{-1}\right) \\
\text { per unit deposition }\end{array}$ & DIL $\left(\mathrm{Bq} \mathrm{L}^{-1}\right)$ & $\begin{array}{c}\text { Deposition of mix corresponding } \\
\text { to 1 DIL }\left(\mathrm{Ci} \mathrm{m}^{-2}\right)\end{array}$ \\
\hline Pu-238 + Pu-239 + Am-241 & $6.38 \mathrm{E}-07$ & 2 & $8.47 \mathrm{E}-05$ \\
Pu-241 & $8.25 \mathrm{E}-06$ & 120 & $3.93 \mathrm{E}-04$ \\
\hline
\end{tabular}

Table Q-4 presents depositions necessary to equal a DIL for the Pu-238 + Pu-239 + Am-241 group and the individual radionuclide Pu-241. The activity of the depositions includes that from all radionuclides in the mix, even though the radionuclide(s) in a limiting group may only be a small fraction of the total activity released. The most limiting radionuclide group for the milk pathway is the $\mathrm{Pu}-238+\mathrm{Pu}-239+\mathrm{Am}-241$ group.

The processes outlined above may be repeated for other pathways. Table Q-5 lists total depositions of the radionuclide mix (in $\mathrm{Ci} \mathrm{m}^{-2}$ ) corresponding to $1 \mathrm{DIL}$ of the $\mathrm{Pu}-238+\mathrm{Pu}-239+$ Am-241 group and the individual radionuclide $\mathrm{Pu}-241$ for all pathways. 
Table Q-5. Derived response levels for all pathways

\begin{tabular}{|c|c|c|}
\hline \multirow[t]{2}{*}{ Pathway } & \multicolumn{2}{|c|}{$\begin{array}{c}\text { Deposition of mix }\left(\mathrm{Ci} \mathrm{m}^{-2}\right) \text { corresponding to } 1 \mathrm{DIL} \text { of } \\
\text { nuclide group }\end{array}$} \\
\hline & $\mathrm{Pu}-238+\mathrm{Pu}-239+\mathrm{Am}-241$ & $\mathrm{Pu}-241$ \\
\hline Milk & $8.47 \mathrm{E}-05$ & $3.93 \mathrm{E}-04$ \\
\hline Egg contents & $1.67 \mathrm{E}-05$ & $2.11 \mathrm{E}-04$ \\
\hline Beef & $5.96 \mathrm{E}-06$ & $4.66 \mathrm{E}-05$ \\
\hline Veal & $3.49 \mathrm{E}-07$ & $1.46 \mathrm{E}-06$ \\
\hline Sheep & $4.08 \mathrm{E}-06$ & $2.27 \mathrm{E}-05$ \\
\hline Lamb & $1.77 \mathrm{E}-07$ & $8.12 \mathrm{E}-07$ \\
\hline Pork & $2.57 \mathrm{E}-06$ & $1.43 \mathrm{E}-05$ \\
\hline Poultry & $2.46 \mathrm{E}-06$ & $1.33 \mathrm{E}-05$ \\
\hline Fish & 2.78E-08 & $1.17 \mathrm{E}-07$ \\
\hline Produce-direct deposition & 2.91E-09 & $1.22 \mathrm{E}-08$ \\
\hline Produce - root uptake & $6.74 \mathrm{E}-03$ & 9.39E-02 \\
\hline Produce-soil adhesion & $1.63 \mathrm{E}-04$ & $6.85 \mathrm{E}-04$ \\
\hline Grain-direct deposition & 2.91E-09 & $1.22 \mathrm{E}-08$ \\
\hline Grain-root uptake & $2.18 \mathrm{E}-02$ & $1.32 \mathrm{E}-01$ \\
\hline Grain-soil adhesion & $6.78 \mathrm{E}-05$ & $2.85 \mathrm{E}-04$ \\
\hline Beverage & $8.33 \mathrm{E}-07$ & $3.50 \mathrm{E}-06$ \\
\hline
\end{tabular}

In all cases, the Pu-238 + Pu-239 + Am-241 group is more limiting than Pu-241, reaching a DIL of the $\mathrm{Pu}-238+\mathrm{Pu}-239+\mathrm{Am}-241$ group at a lower areal deposition than $\mathrm{Pu}-241$. Since DILs are not additive between groups, the following discussion focuses on the $\mathrm{Pu}-238+\mathrm{Pu}-239+$ Am-241 group only.

Table Q-6 ranks the pathways by the deposition needed to reach a DIL of the Pu-238 + Pu-239+ Am-241 group. 
Table Q-6. Food pathways ranked by DRL

\begin{tabular}{lc}
\hline Pathway & $\begin{array}{c}\text { Deposition of mix }\left(\mathrm{Ci} \mathrm{m}{ }^{-2}\right) \text { corresponding to } \\
\text { 1 DIL of Pu-238 }+ \text { Pu-239 }+ \text { Am-241group }\end{array}$ \\
\hline Produce-direct deposition & $2.91 \mathrm{E}-09$ \\
Grain-direct deposition & $2.91 \mathrm{E}-09$ \\
Fish & $2.78 \mathrm{E}-08$ \\
Lamb & $1.77 \mathrm{E}-07$ \\
Veal & $3.49 \mathrm{E}-07$ \\
Beverage & $8.33 \mathrm{E}-07$ \\
Poultry & $2.46 \mathrm{E}-06$ \\
Pork & $2.57 \mathrm{E}-06$ \\
Sheep & $4.08 \mathrm{E}-06$ \\
Beef & $5.96 \mathrm{E}-06$ \\
Egg contents & $1.67 \mathrm{E}-05$ \\
Grain-soil adhesion & $6.78 \mathrm{E}-05$ \\
Milk & $8.47 \mathrm{E}-05$ \\
Produce-soil adhesion & $1.63 \mathrm{E}-04$ \\
Produce - root uptake & $6.74 \mathrm{E}-03$ \\
Grain-root uptake & $2.18 \mathrm{E}-02$ \\
\hline
\end{tabular}

The direct deposition pathways reach the DIL first (i.e., they have the lowest DRLs). These pathways are important only for crops in the field at the time of airborne plume passage. The fish pathway is modeled for fish in stagnant ponds with no absorption of the radionuclides into the sediment. The ranking reflects the bioaccumulation factors for fish that are greater than unity. The meat pathways postulate ingestion of fodder contaminated by directly deposited radionuclides; fodder grown after the deposition and subsequently fed to animals would result in much lower concentrations in animal products.

\section{Determination of range and area of consequences}

The HOTSPOT computer code (Homann 1994) was selected to evaluate the consequences of particulate releases. In the following calculations, a source term equal to the total activity of $35.1 \mathrm{Ci}$ is used, and the range and area affected for different meteorological parameters and DRLs found. The specific HOTSPOT Parameters used for the H-Area Coil \& Tube release are listed in Table Q-7. 
Table Q-7. HOTSPOT Parameters used for the H-Separations Coil \& Tube release

\begin{tabular}{lll}
\hline Parameter & Average Meteorology & $95 \%$ Adverse Meteorology \\
\hline Release height & Ground & Ground \\
Wind speed & $2.5 \mathrm{~m} / \mathrm{s}$ & $1.7 \mathrm{~m} / \mathrm{s}$ \\
Surface roughness & $100 \mathrm{~cm}$ & $100 \mathrm{~cm}$ \\
Stability class & $\mathrm{C}$ & $\mathrm{E}$ \\
Deposition velocity & $0.1 / 1 / 10 \mathrm{~cm} / \mathrm{sec}$ & $0.1 / 1 / 10 \mathrm{~cm} / \mathrm{sec}$ \\
Release duration & $120 \mathrm{~min}$ & $120 \mathrm{~min}$ \\
Inversion layer & $500 \mathrm{~m}$ & $200 \mathrm{~m}$ \\
\hline
\end{tabular}

Meteorological data is consistent with TP-95-002, Revision 3, Consequence Assessment for Emergency Preparedness Hazards Assessments (Hadlock 1997).

\section{RESULTS}

Tables Q-8 and Q-9 summarize ingestion pathway consequences for adverse meteorology. If a contour (DRL) is not exceeded and/or the area affected is insignificant, " $\mathrm{N} / \mathrm{E}$ " is entered for the value. Figure Q-1 is typical of a plot produced by the HOTSPOT runs for adverse meteorology and a deposition velocity of $1 \mathrm{~cm} \mathrm{~s}^{-1}$. The contours of 5.96, 4.08, and $2.57 \mu \mathrm{Ci} \mathrm{m}$ correspond to the DRLs for beef, sheep, and pork pathways, respectively.

Table Q-8. Ranges until deposition less than DRL, 95\% adverse meteorology, for three deposition velocities

\begin{tabular}{lcccc}
\hline Pathway & $\begin{array}{c}\mathrm{DRL} \\
(\mathrm{Ci} \mathrm{m}-2\end{array}$ & $\begin{array}{c}0.1 \mathrm{~cm} \mathrm{~s}^{-1} \\
(\mathrm{~km})\end{array}$ & $\begin{array}{c}1 \mathrm{~cm} \mathrm{~s}^{-1} \\
(\mathrm{~km})\end{array}$ & $\begin{array}{c}10 \mathrm{~cm} \mathrm{~s}^{-1} \\
(\mathrm{~km})\end{array}$ \\
\hline Produce-direct deposition & $2.91 \mathrm{E}-09$ & $>100$ & $>100$ & $>100$ \\
Grain-direct deposition & $2.91 \mathrm{E}-09$ & $>100$ & $>100$ & $>100$ \\
Fish & $2.78 \mathrm{E}-08$ & 25 & $>100$ & 32 \\
Lamb & $1.77 \mathrm{E}-07$ & 3 & 30 & 7 \\
Veal & $3.49 \mathrm{E}-07$ & 1.8 & 11 & 4 \\
Beverage & $8.33 \mathrm{E}-07$ & 1.0 & 4 & 2.5 \\
Poultry & $2.46 \mathrm{E}-06$ & 0.5 & 2 & 1.5 \\
Pork & $2.57 \mathrm{E}-06$ & 0.5 & 2 & 1.5 \\
Sheep & $4.08 \mathrm{E}-06$ & 0.4 & 1.4 & 1.1 \\
Beef & $5.96 \mathrm{E}-06$ & 0.3 & 1.0 & 0.9 \\
Egg contents & $1.67 \mathrm{E}-05$ & 0.2 & 0.6 & 0.6 \\
Grain-soil adhesion & $6.78 \mathrm{E}-05$ & 0.09 & 0.3 & 0.3 \\
Milk & $8.47 \mathrm{E}-05$ & 0.08 & 0.2 & 0.28 \\
Produce-soil adhesion & $1.63 \mathrm{E}-04$ & 0.06 & 0.16 & 0.25 \\
Produce - root uptake & $6.74 \mathrm{E}-03$ & $\mathrm{~N} / \mathrm{E}$ & 0.025 & 0.05 \\
Grain-root uptake & $2.18 \mathrm{E}-02$ & $\mathrm{~N} / \mathrm{E}$ & 0.015 & 0.035 \\
\hline
\end{tabular}


Table Q-9. Areas above DRL, 95\% adverse meteorology, for three deposition velocities

\begin{tabular}{lcccc}
\hline Pathway & $\begin{array}{c}\mathrm{DRL} \\
(\mathrm{Ci} \mathrm{m})^{-2}\end{array}$ & $\begin{array}{c}0.1 \mathrm{~cm} \mathrm{~s}^{-1} \\
\left(\mathrm{~km}^{2}\right)\end{array}$ & $\begin{array}{c}1 \mathrm{~cm} \mathrm{~s}^{-1} \\
\left(\mathrm{~km}^{2}\right)\end{array}$ & $\begin{array}{c}10 \mathrm{~cm} \mathrm{~s}^{-1} \\
\left(\mathrm{~km}^{2}\right)\end{array}$ \\
\hline Produce-direct deposition & $2.91 \mathrm{E}-09$ & $>6.0 \mathrm{E}+02$ & $>8.6 \mathrm{E}+02$ & $>5.7 \mathrm{E}+02$ \\
Grain-direct deposition & $2.91 \mathrm{E}-09$ & $>6.0 \mathrm{E}+02$ & $>8.6 \mathrm{E}+02$ & $>5.7 \mathrm{E}+02$ \\
Fish & $2.78 \mathrm{E}-08$ & $2.2 \mathrm{E}+01$ & $>5.3 \mathrm{E}+02$ & $3.9 \mathrm{E}+01$ \\
Lamb & $1.77 \mathrm{E}-07$ & $7.3 \mathrm{E}-01$ & $2.6 \mathrm{E}+01$ & $3.3 \mathrm{E}+00$ \\
Veal & $3.49 \mathrm{E}-07$ & $3.2 \mathrm{E}-01$ & $5.1 \mathrm{E}+00$ & $1.8 \mathrm{E}+00$ \\
Beverage & $8.33 \mathrm{E}-07$ & $1.1 \mathrm{E}-01$ & $1.4 \mathrm{E}+00$ & $7.5 \mathrm{E}-01$ \\
Poultry & $2.46 \mathrm{E}-06$ & $3.2 \mathrm{E}-02$ & $3.5 \mathrm{E}-01$ & $2.7 \mathrm{E}-01$ \\
Pork & $2.57 \mathrm{E}-06$ & $3.1 \mathrm{E}-02$ & $3.4 \mathrm{E}-01$ & $2.6 \mathrm{E}-01$ \\
Sheep & $4.08 \mathrm{E}-06$ & $1.9 \mathrm{E}-02$ & $2.0 \mathrm{E}-01$ & $1.7 \mathrm{E}-01$ \\
Beef & $5.96 \mathrm{E}-06$ & $1.2 \mathrm{E}-02$ & $1.3 \mathrm{E}-01$ & $1.3 \mathrm{E}-01$ \\
Egg contents & $1.67 \mathrm{E}-05$ & $4.1 \mathrm{E}-03$ & $4.0 \mathrm{E}-02$ & $5.2 \mathrm{E}-02$ \\
Grain-soil adhesion & $6.78 \mathrm{E}-05$ & $\mathrm{~N} / \mathrm{E}$ & $8.9 \mathrm{E}-03$ & $1.6 \mathrm{E}-02$ \\
Milk & $8.47 \mathrm{E}-05$ & $\mathrm{~N} / \mathrm{E}$ & $7.1 \mathrm{E}-03$ & $1.4 \mathrm{E}-02$ \\
Produce-soil adhesion & $1.63 \mathrm{E}-04$ & $\mathrm{~N} / \mathrm{E}$ & $3.7 \mathrm{E}-03$ & $8.0 \mathrm{E}-03$ \\
Produce - root uptake & $6.74 \mathrm{E}-03$ & $\mathrm{~N} / \mathrm{E}$ & $\mathrm{N} / \mathrm{E}$ & $\mathrm{N} / \mathrm{E}$ \\
Grain-root uptake & $2.18 \mathrm{E}-02$ & $\mathrm{~N} / \mathrm{E}$ & N/E & N/E \\
\hline
\end{tabular}


Figure Q-1. Typical HOTSPOT plot for adverse meteorology run

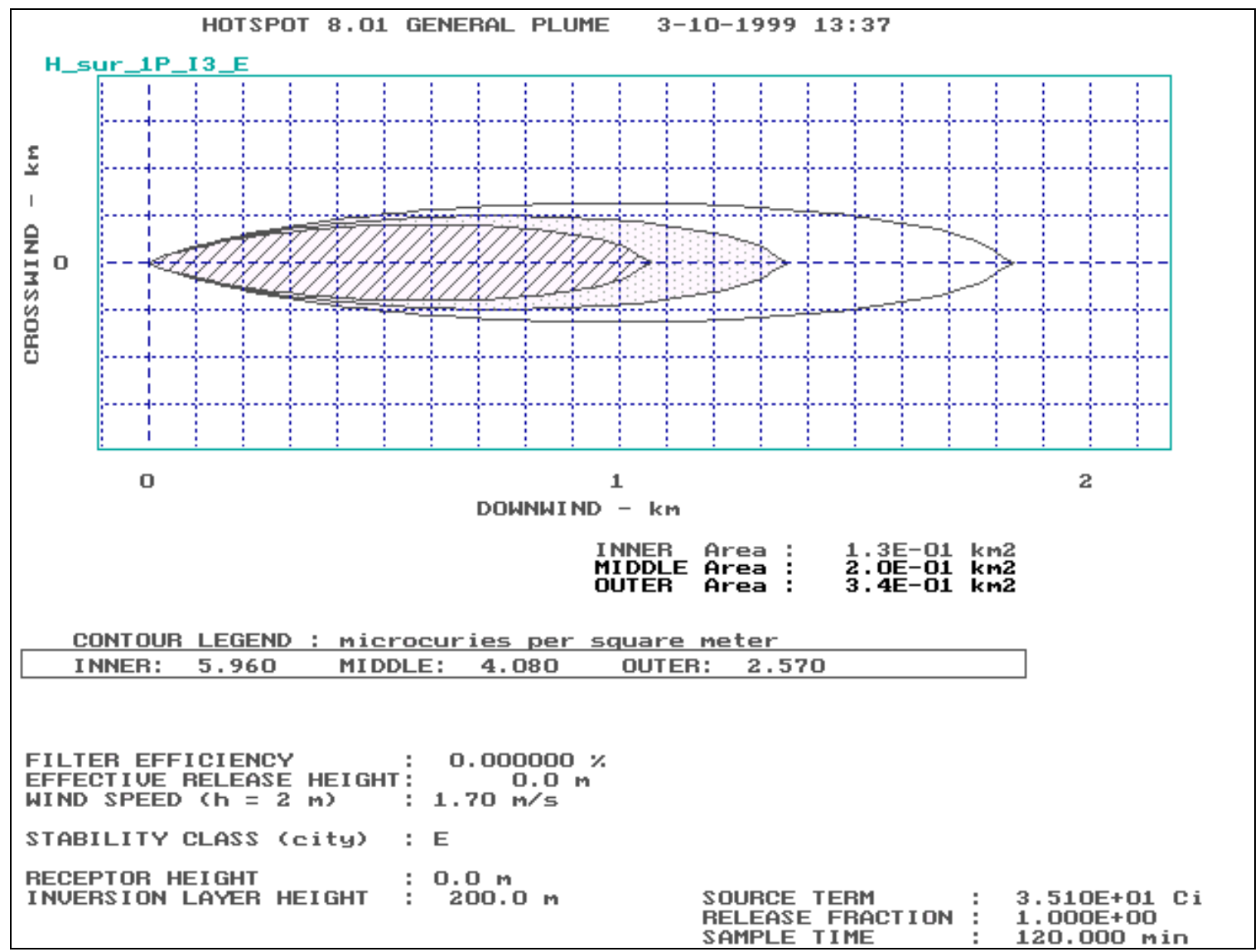

Tables Q-10 and Q-11 summarize ingestion pathway consequences for average meteorology. If a contour (DRL) is not exceeded and/or the area affected is insignificant, "N/E" is entered for the value. Figure Q-2 is typical of a plot produced by the HOTSPOT runs for average meteorology and a deposition velocity of $1 \mathrm{~cm} \mathrm{~s}^{-1}$. Contours correspond to the beef (inner), sheep (middle), and pork (outer) DRLs. 
Table Q-10. Ranges until deposition less than DRL, average meteorology, for three deposition velocities

\begin{tabular}{lcccc}
\hline Pathway & $\begin{array}{c}\mathrm{DRL} \\
\left(\mathrm{Ci} \mathrm{m}^{-2}\right)\end{array}$ & $\begin{array}{c}0.1 \mathrm{~cm} \mathrm{~s}^{-1} \\
(\mathrm{~km})\end{array}$ & $\begin{array}{c}1 \mathrm{~cm} \mathrm{~s}^{-1} \\
(\mathrm{~km})\end{array}$ & $\begin{array}{c}10 \mathrm{~cm} \mathrm{~s}^{-1} \\
(\mathrm{~km})\end{array}$ \\
\hline Produce-direct deposition & $2.91 \mathrm{E}-09$ & 40 & $>100$ & $>100$ \\
Grain-direct deposition & $2.91 \mathrm{E}-09$ & 40 & $>100$ & $>100$ \\
Fish & $2.78 \mathrm{E}-08$ & 1.5 & 40 & $>100$ \\
Lamb & $1.77 \mathrm{E}-07$ & 0.6 & 2.0 & 15 \\
Veal & $3.49 \mathrm{E}-07$ & 0.45 & 1.5 & 6.0 \\
Beverage & $8.33 \mathrm{E}-07$ & 0.3 & 0.9 & 2.0 \\
Poultry & $2.46 \mathrm{E}-06$ & 0.15 & 0.5 & 1.2 \\
Pork & $2.57 \mathrm{E}-06$ & 0.15 & 0.5 & 1.2 \\
Sheep & $4.08 \mathrm{E}-06$ & 0.10 & 0.4 & 0.9 \\
Beef & $5.96 \mathrm{E}-06$ & 0.10 & 0.3 & 0.75 \\
Egg contents & $1.67 \mathrm{E}-05$ & 0.06 & 0.2 & 0.5 \\
Grain-soil adhesion & $6.78 \mathrm{E}-05$ & 0.03 & 0.1 & 0.25 \\
Milk & $8.47 \mathrm{E}-05$ & 0.03 & 0.08 & 0.2 \\
Produce-soil adhesion & $1.63 \mathrm{E}-04$ & 0.02 & 0.06 & 0.15 \\
Produce - root uptake & $6.74 \mathrm{E}-03$ & $\mathrm{~N} / \mathrm{E}$ & 0.01 & 0.03 \\
Grain-root uptake & $2.18 \mathrm{E}-02$ & $\mathrm{~N} / \mathrm{E}$ & $\mathrm{N} / \mathrm{E}$ & 0.015 \\
\hline
\end{tabular}

Table Q-11. Areas above DRL, average meteorology, for three deposition velocities

\begin{tabular}{lcccc}
\hline Pathway & $\begin{array}{c}\mathrm{DRL} \\
(\mathrm{Ci} \mathrm{m})^{-2}\end{array}$ & $\begin{array}{c}0.1 \mathrm{~cm} \mathrm{~s}^{-1} \\
\left(\mathrm{~km}^{2}\right)\end{array}$ & $\begin{array}{c}1 \mathrm{~cm} \mathrm{~s}^{-1} \\
\left(\mathrm{~km}^{2}\right)\end{array}$ & $\begin{array}{c}10 \mathrm{~cm} \mathrm{~s}^{-1} \\
\left(\mathrm{~km}^{2}\right)\end{array}$ \\
\hline Produce-direct deposition & $2.91 \mathrm{E}-09$ & $1.0 \mathrm{E}+02$ & $>1.3 \mathrm{E}+03$ & $>1.6 \mathrm{E}+03$ \\
Grain-direct deposition & $2.91 \mathrm{E}-09$ & $1.0 \mathrm{E}+02$ & $>1.3 \mathrm{E}+03$ & $>1.6 \mathrm{E}+03$ \\
Fish & $2.78 \mathrm{E}-08$ & $5.8 \mathrm{E}-01$ & $8.6 \mathrm{E}+01$ & $>8.7 \mathrm{E}+02$ \\
Lamb & $1.77 \mathrm{E}-07$ & $9.9 \mathrm{E}-02$ & $8.0 \mathrm{E}-01$ & $2.0 \mathrm{E}+01$ \\
Veal & $3.49 \mathrm{E}-07$ & $5.0 \mathrm{E}-02$ & $4.8 \mathrm{E}-01$ & $4.7 \mathrm{E}+00$ \\
Beverage & $8.33 \mathrm{E}-07$ & $2.1 \mathrm{E}-02$ & $2.0 \mathrm{E}-01$ & $9.8 \mathrm{E}-01$ \\
Poultry & $2.46 \mathrm{E}-06$ & $6.7 \mathrm{E}-03$ & $6.7 \mathrm{E}-02$ & $3.5 \mathrm{E}-01$ \\
Pork & $2.57 \mathrm{E}-06$ & $6.4 \mathrm{E}-03$ & $6.4 \mathrm{E}-02$ & $3.4 \mathrm{E}-01$ \\
Sheep & $4.08 \mathrm{E}-06$ & $4.1 \mathrm{E}-03$ & $4.0 \mathrm{E}-02$ & $2.2 \mathrm{E}-01$ \\
Beef & $5.96 \mathrm{E}-06$ & $2.6 \mathrm{E}-03$ & $2.8 \mathrm{E}-02$ & $1.5 \mathrm{E}-01$ \\
Egg contents & $1.67 \mathrm{E}-05$ & $\mathrm{~N} / \mathrm{E}$ & $9.9 \mathrm{E}-03$ & $5.8 \mathrm{E}-02$ \\
Grain-soil adhesion & $6.78 \mathrm{E}-05$ & $\mathrm{~N} / \mathrm{E}$ & $\mathrm{N} / \mathrm{E}$ & $1.5 \mathrm{E}-02$ \\
Milk & $8.47 \mathrm{E}-05$ & $\mathrm{~N} / \mathrm{E}$ & $\mathrm{N} / \mathrm{E}$ & $1.3 \mathrm{E}-02$ \\
Produce-soil adhesion & $1.63 \mathrm{E}-04$ & $\mathrm{~N} / \mathrm{E}$ & $\mathrm{N} / \mathrm{E}$ & $6.7 \mathrm{E}-03$ \\
Produce - root uptake & $6.74 \mathrm{E}-03$ & $\mathrm{~N} / \mathrm{E}$ & $\mathrm{N} / \mathrm{E}$ & N/E \\
Grain-root uptake & $2.18 \mathrm{E}-02$ & $\mathrm{~N} / \mathrm{E}$ & $\mathrm{N} / \mathrm{E}$ & N/E \\
\hline
\end{tabular}


Figure Q-2. Typical HOTSPOT plot for average meteorology run

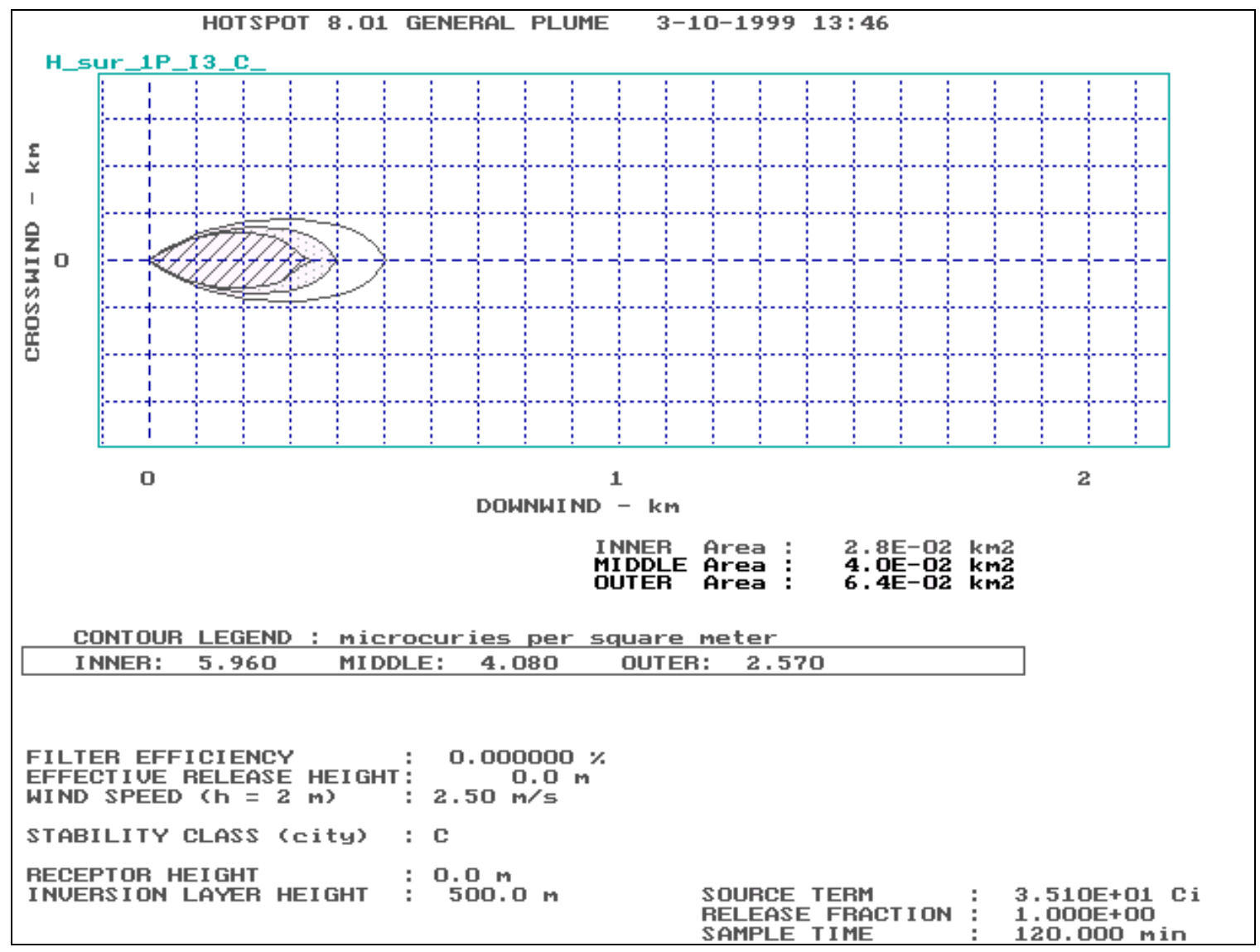

The results presented in Thompson (1999b) demonstrate that higher deposition rates may not always result in consequences being manifest at greater ranges or larger areas. This is due to the plume being depleted close to the source at high deposition rates, thereby leaving less material to deposit far from the source.

\section{CONCLUSION}

Tables Q-8 to Q-11 present ingestion pathway consequences from H-Separations accident scenario 1-RD-2.35, Coil and Tube Failure. The Pu-238 + Pu-239 + Am-241 group is the most limiting for all pathways. The most significant pathways are those involving ingestion of freshly deposited radionuclides on produce and grain. Contamination of produce and grain exceeds FDA guidelines out to at least $40 \mathrm{~km}$ in all cases, and out to greater than $100 \mathrm{~km}$ in most cases. Additionally, under some conditions, it may be possible for fish and lamb foodstuffs to exceed FDA guidelines offsite. Sampling and analysis of these pathways would be recommended. Ranges for all other pathways are less than the distance to the site boundary (approximately $11 \mathrm{~km}$ ), so protective actions for these other pathways would not be recommended for offsite locations. 


\section{APPENDIX R. SAMPLE UFOTRI INPUT FILE}

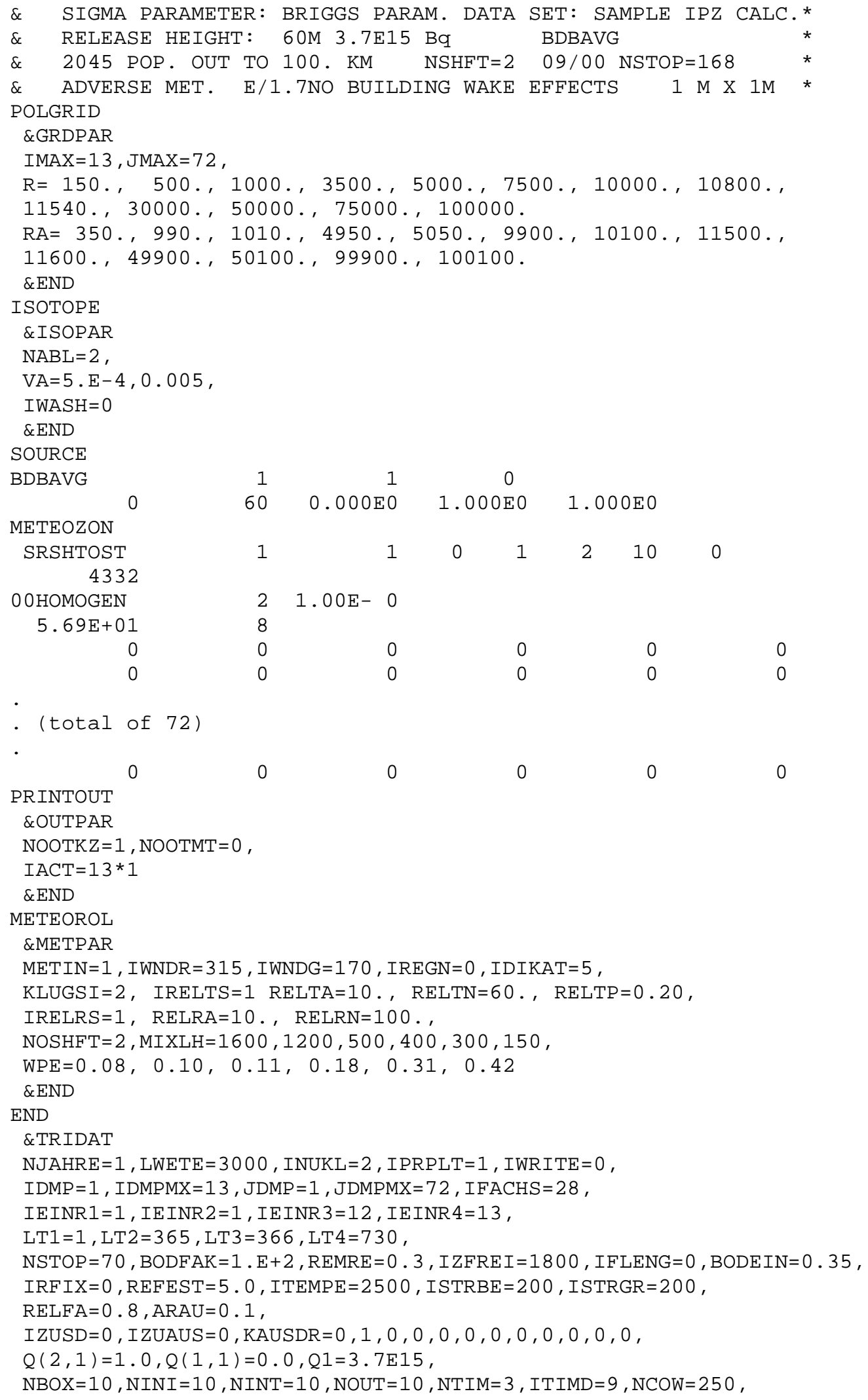


WWCOW $=350$, WOCOW $=150$.

TIMEDO $=0,3 ., 7 ., 14 ., 21 ., 30 ., 90 ., 180 ., 200 ., 365 ., 370 ., 3650 .$,

$\mathrm{FAKC} 1=0.5, \mathrm{FAKC} 2=0.35, \mathrm{FAKCP}=0.05, \mathrm{FAKCW}=0.1$,

$\mathrm{RCMIN}=2$. , $\mathrm{LEAF}=3 ., \mathrm{BEWG}=1440, \mathrm{BEWGZ}=160$,

RCMIN2 $=2$, , LEAF $2=3 ., \mathrm{BEWG} 2=680, \mathrm{BEWGZ2}=170$,

$\mathrm{RCMINP}=2 ., \mathrm{LEAFP}=4.7, \mathrm{BEWGP}=2700 ., \mathrm{BEWGZP}=300$.

$\mathrm{RCMINW}=2$. , $\mathrm{LEAFW}=7$. , $\mathrm{BEWGW}=2000$, $\mathrm{BEWGZW=500}$, ,

IPOT=233, IWHEAT=2 61, IMILK=315, IVEGE=124, IMEAT=206, DOSF=1.7E-11,

$\mathrm{DOSHT}=1.7 \mathrm{E}-15, \mathrm{DOSFOB}=4.0 \mathrm{E}-11, \mathrm{BRRATE}=3.33 \mathrm{E}-4, \mathrm{SKRATE}=1.665 \mathrm{E}-04$,

IMODEL $=1, \operatorname{IARTBO}=2, \mathrm{WILTP}=0.1, \operatorname{SOILMX}=0.5, \operatorname{IBODEX}=1$,

$\mathrm{IMONT}=1, \mathrm{IRRIGA}=0$, IRRIGG $=0$, IFLAGS $=1, \mathrm{IFLAGR}=1, \mathrm{IDEPHT}=1$,

IBODFX $=0, \operatorname{ICOVER}=1, \operatorname{IRELIN}=181, \mathrm{IPHOTO}=1, \mathrm{IARIV}=0$

$\&$ END 